\title{
Stereoselective Activity of 1-Propargyl-4-styrylpiperidine-like Analogues That Can Discriminate between Monoamine Oxidase Isoforms A and B
}

Damijan Knez, "Natalia Colettis, "Luca G. Iacovino," Matej Sova, Anja Pǐ̌lar, Janez Konc, Samo Lešnik, Josefina Higgs, Fabiola Kamecki, Irene Mangialavori, Ana Dolšak, Simon Žakelj, Jurij Trontelj, Janko Kos, Claudia Binda,* Mariel Marder,* and Stanislav Gobec*

Cite This: J. Med. Chem. 2020, 63, 1361-1387

Read Online

ABSTRACT: The resurgence of interest in monoamine oxidases (MAOs) has been fueled by recent correlations of this enzymatic activity with cardiovascular, neurological, and oncological disorders. This has promoted increased research into selective MAO$\mathrm{A}$ and MAO-B inhibitors. Here, we shed light on how selective inhibition of MAO-A and MAO-B can be achieved by geometric isomers of cis- and trans-1-propargyl-4-styrylpiperidines. While the cis isomers are potent human MAO-A inhibitors, the trans analogues selectively target only the MAO-B isoform. The inhibition was studied by kinetic analysis, UV-vis spectrum measurements, and $\mathrm{X}$-ray crystallography. The selective inhibition of the MAO-A and MAO-B isoforms was confirmed ex vivo in mouse brain homogenates, and additional in vivo studies in mice

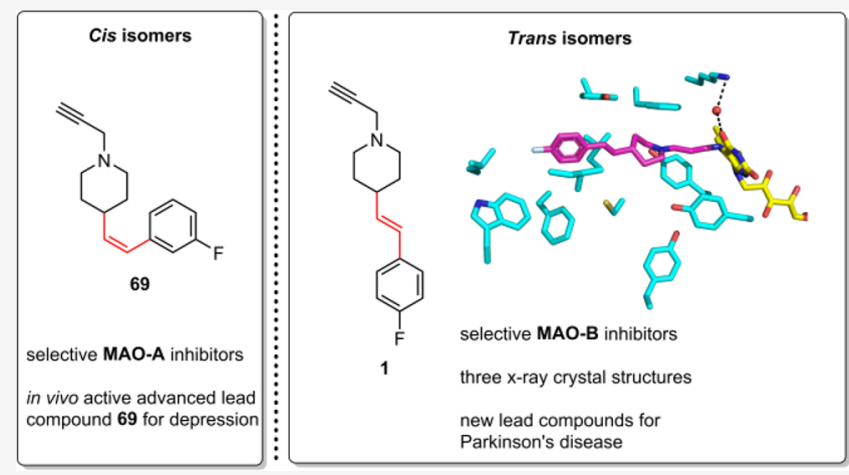
show the therapeutic potential of 1-propargyl-4-styrylpiperidines for central nervous system disorders. This study represents a unique case of stereoselective activity of cis/trans isomers that can discriminate between structurally related enzyme isoforms.

\section{INTRODUCTION}

Specific interaction patterns and molecular geometry are critical factors that influence ligand binding affinity and ligand selectivity toward a target. ${ }^{1}$ Numerous examples of "chiral switching" in drug development have highlighted the effects of spatial geometry on not only pharmacodynamics but also pharmacokinetics and toxicology of drugs. ${ }^{2,3}$ In addition to optical isomers, cis and trans isomers can have different pharmacological activities, as demonstrated by the well-known cases of cisplatin, ${ }^{4}$ tamoxifen, ${ }^{5}$ and combretastatin A4 (CA-4). ${ }^{6}$ This last includes a stilbene motif in the cis conformation (Figure 1A), which efficiently binds to the colchicine binding site of tubulin and acts as a microtubule-destabilizing agent. ${ }^{6}$ The binding of trans-combretastatin A4 (trans-CA-4, Figure 1A) to this site is thermodynamically less stable than that of cis-combretastatin A4 (cis-CA-4), and consequently the trans conformation does not prevent microtubule assembly. ${ }^{6}$ However, examples of stereoselective activities of cis/trans isomers are rare in comparison with optical isomers.

Human monoamine oxidase A (hMAO-A) and human monoamine oxidase B (hMAO-B) are flavoenzymes that are encoded by separate genes on the $\mathrm{X}$ chromosome, and they share $70 \%$ sequence identity. ${ }^{7}$ They are differentiated by their substrate specificities and inhibitor sensitivities. This arises from the differences in the active site size and shape, and the altered amino acid residues between these isoforms. The hMAO-A and hMAO-B active sites are hydrophobic cavities with volumes of about $550 \AA^{3}$ and $700 \AA^{3}$, respectively. ${ }^{8}$ The active site of hMAO-B is flat and elongated, with a bipartite configuration, where Ile199 and Tyr326 are the gating residues that determine the shape of the cavity and the specificity of substrate/inhibitor binding. ${ }^{9}$ hMAO-A has a monopartite and more spherical active site, with Ile335 and Phe208 as the gating residues. MAOs catalyze the oxidative deamination of primary and some secondary amines, and they are responsible for neurotransmitter metabolism in peripheral tissues and in the central nervous system. ${ }^{10}$ This reaction produces an imino intermediate, which is spontaneously hydrolyzed to the corresponding aldehyde, with ammonia and hydrogen peroxide as side-products. ${ }^{11}$ Reduced levels of neurotransmitters, increased activity and levels of MAOs, and the production of

Received: November 14, 2019

Published: January 9, 2020 
A<smiles>COc1cc(/C=C\c2cc(OC)c(OC)c(OC)c2)cc(OC)c1OC</smiles>

cis-CA-4<smiles>COc1ccc(/C=C/c2cc(OC)c(OC)c(OC)c2)cc1O</smiles>

trans-CA-4
B

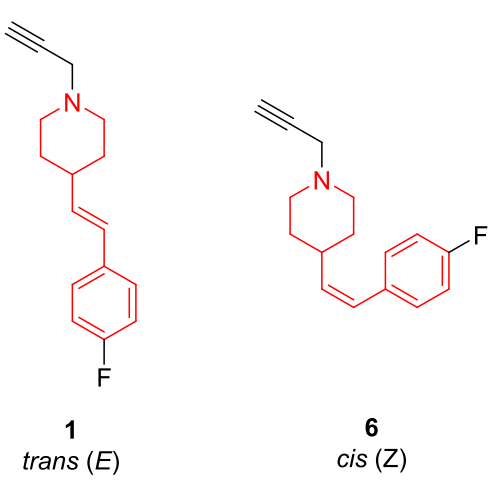

C

\begin{tabular}{cccc}
\hline Compound & IC $_{50}(\mathrm{hMAO}-\mathrm{A})^{\mathrm{a}}[\boldsymbol{\mu M}]$ & $\mathrm{IC}_{50}(\mathrm{hMAO}-\mathrm{B})^{\mathrm{a}}[\boldsymbol{\mu M}]$ & Selectivity Ratio $^{b}$ \\
\hline $\mathbf{1}$ (trans) & $>100$ & $0.3422 \pm 0.0224$ & $>292$ \\
$\mathbf{6}$ (cis) & $0.7261 \pm 0.0269$ & $6.2215 \pm 0.7268$ & 0.12 \\
\hline
\end{tabular}

Figure 1. Stilbene derivatives and MAO inhibitory potencies. Chemical structures of cis/trans-combretastatin A4 (CA-4) (A) and hit inhibitor 1 (B) and cis isomer 6 (B). The stilbene core is blue, and the stilbene-like moiety of inhibitor $\mathbf{1}$ is red. (C) ${ }^{\mathrm{a}} \mathrm{IC}_{50}$ values are mean \pm SEM values $(n=$ $2,3)$. ${ }^{b}$ Selectivity ratio is defined as $\mathrm{IC}_{50}(\mathrm{hMAO}-\mathrm{A}) / \mathrm{IC}_{50}(\mathrm{hMAO}-\mathrm{B})$.

\section{Scheme 1. Resynthesis of Hit Inhibitor $1^{a}$}

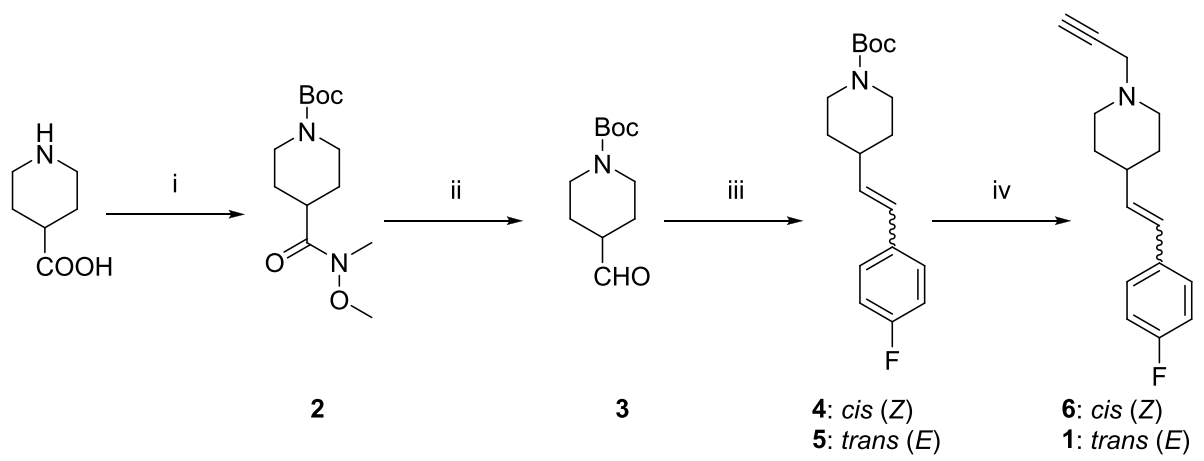

${ }^{a}$ Reagents and conditions: (i) 1) $\mathrm{Boc}_{2} \mathrm{O}, 1.0 \mathrm{M} \mathrm{NaOH}, 1,4$-dioxane, $\left.0{ }^{\circ} \mathrm{C}, \mathrm{rt}, 1 \mathrm{~h}(91 \%) ; 2\right) \mathrm{N}, \mathrm{O}$-dimethyhydroxylamine hydrochloride, $\mathrm{Et}_{3} \mathrm{~N}$, TBTU, $\mathrm{CH}_{2} \mathrm{Cl}_{2}, 0{ }^{\circ} \mathrm{C}$ to rt, overnight (76\%); (ii) $\mathrm{LiAlH}_{4}$, anh THF, $0{ }^{\circ} \mathrm{C}, 1 \mathrm{~h}$ (crude product, 83\%); (iii) (4-fluorobenzyl)triphenylphosphonium bromide, sodium bis(trimethylsilyl)amide (NaHMDS, $2 \mathrm{~N}$ in THF), anh THF, $\mathrm{Ar}(\mathrm{g})$, rt, overnight (52\%); (iv) (1) 4.0 M HCl in 1,4-dioxane, 80 ${ }^{\circ} \mathrm{C}, 2 \mathrm{~h}(100 \%)$; (2) propargyl bromide (80\% solution in toluene), $\mathrm{Cs}_{2} \mathrm{CO}_{3}, \mathrm{DMF}, \mathrm{Ar}(\mathrm{g}), 0{ }^{\circ} \mathrm{C}$, rt, overnight (yield, 1, 26\%; 6, 72\%).

toxic metabolites are linked with various neurological, ${ }^{12,13}$ psychological, ${ }^{14}$ and cardiovascular disorders ${ }^{15}$ and cancers. ${ }^{16}$

MAO-A inhibitors have been widely used for several decades in the therapy of depression and affective disorders. ${ }^{17}$ On the other hand, selective MAO-B inhibitors are used as monotherapies in the early stages of Parkinson's disease and as add-on therapy to levodopa in advanced forms of Parkinson's disease. ${ }^{18}$ MAO-A and MAO-B are recognized as validated targets. In terms of their contribution to increased cellular oxidative stress, ${ }^{19}$ novel inhibitors are emerging as important disease-modifying therapeutic agents in such devastating neurodegenerative diseases as Alzheimer's disease and a number of others. ${ }^{20}$

To the best of our knowledge, cis/trans isomerisms of double bonds have never been used to achieve stereoselective inhibition of MAO isoforms. Here, we demonstrate a unique case study whereby configuration of the double bond in stilbene-like derivatives can define the selectivity for either MAO-A or MAO-B. We identify 1-propargyl-4-((E)-styryl)piperidines as potent, selective, and irreversible hMAO-B inhibitors. Cis analogues with small substituents on the phenyl ring selectively inhibit hMAO-A. These inhibitors were evaluated for their MAO inhibitory activities and pharmacological properties.

\section{RESULTS}

Identification, Design, Synthesis, and Selectivity Profile of Potent and Selective hMAO-A and hMAO-B Inhibitors. Compound $\mathbf{1}$ (Figure $1 \mathrm{~B}$ ) contains a stilbene-like motif, and it was identified as a hit inhibitor in an in-house library screening campaign. Indeed, compound $\mathbf{1}$ is a potent selective hMAO-B inhibitor, with no significant inhibition of hMAO-A at $100 \mu \mathrm{M}$ (Figure $1 \mathrm{C}$ ).

This hit inhibitor was resynthesised using an efficient and straightforward synthesis (Scheme 1) that started from readily available isonipecotic acid, which was transformed into Weinreb's amide 2 and subsequently reduced to obtain aldehyde 3. The aldehyde then underwent the Wittig reaction with phosphonium ylide to yield a mixture of cis (4) and trans (5) Boc-protected piperidines, which were separated using 


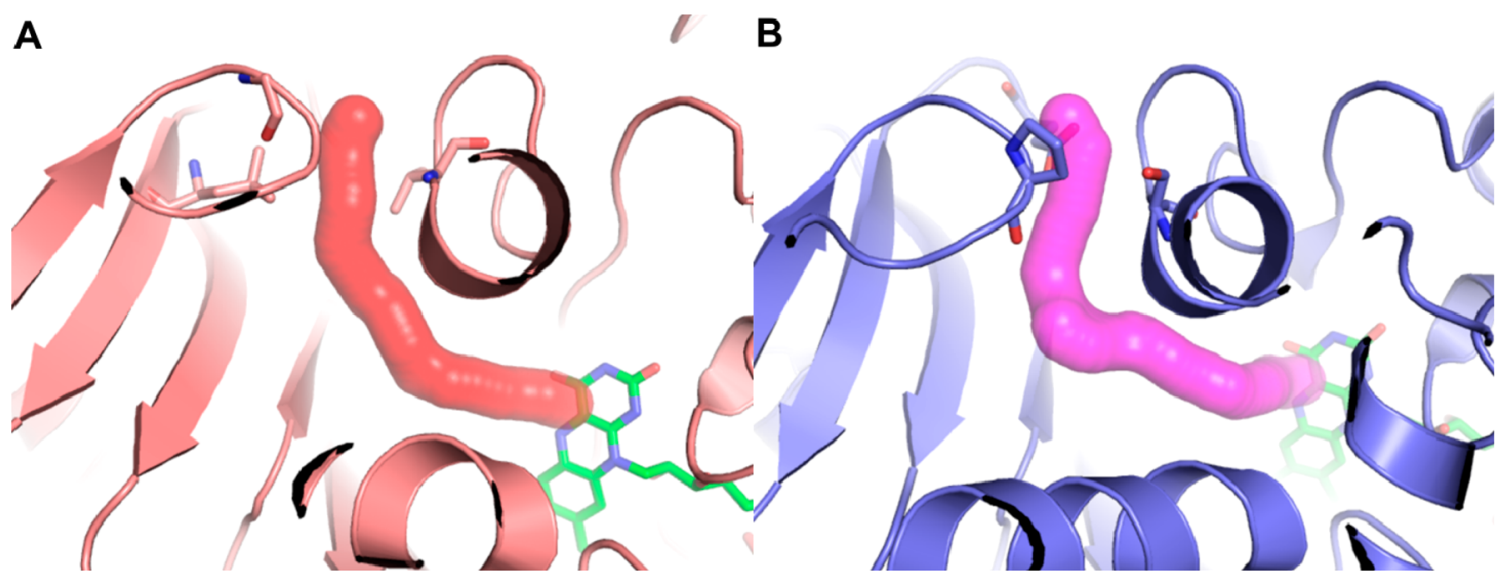

Figure 2. Active sites of hMAO-A (PDB code 2Z5X) and hMAO-B (PDB code 6FVZ). (A) MAO-A; FAD cofactor (green sticks); active site (red surface) spans from FAD to the entrance; bottleneck residues Leu97, Gly110, and Val210 at the entrance (salmon sticks). (B) MAO-B; FAD cofactor (green sticks); active site (violet surface) spans from FAD to the entrance; bottleneck residues Glu84, Pro102, and Ser200 at the entrance (purple sticks).

column chromatography. Following acidolysis, the corresponding secondary amine was reacted with propargyl bromide to obtain hit compound 1 and the cis isomer 6. Compound 6 showed preferential inhibition of hMAO-A over hMAO-B (Figure 1C).

The selectivity profile was explained through analysis of the binding cavity using the Caver tool. ${ }^{21}$ Human (h)MAO-A (Figure 2A) has a wide cavity at the active site near the FAD cofactor $(r=2.1 \AA)$, which is lined with Tyr407, Phe352, and Gly215. In the direction toward the entrance, the cavity widens ( $r \simeq 2.5 \AA$ ) and remains wide to Val210, Gln215, and Ile335, and then it narrows to Val210, Cys323, and Ile335 ( $r=1.9 \AA)$ and remains narrow to the entrance, which is also the narrowest part of the active site $(r=1.9 \AA)$ and is composed of Leu97, Gly110, and Val210. In hMAO-B (Figure 2B), the entrance is even wider in the active site near the $\mathrm{FAD}$ cofactor ( $r=2.3 \AA$ ), with Gln206, Tyr398, and Tyr435, but then narrows in the direction of the entrance $(r=1.9 \AA)$ at Leu171 and Ile199 and then widens again $(r=2.5 \AA)$ to Ile199, Ile316, and Tyr326. The narrowest part is at the entrance $(r=1.6 \AA)$, and it is composed of Glu84, Pro102, and Ser200. The hMAOA active site entrance is thus significantly wider $(r=1.9 \AA)$ than the hMAO-B active site entrance $(r=1.6 \AA)$. Both entrances are also the bottlenecks, which indicates that the active site of hMAO-B might be more difficult to reach by wider ligands.

The active site of hMAO-B is also significantly more curved than the active site of hMAO-A, with a bend of $90^{\circ}$, while in hMAO-A, the cavity bends at an angle of $\sim 60^{\circ}$ (compare Figure $2 \mathrm{~A}, \mathrm{~B}$ ). The narrow entrance of $\mathrm{hMAO}-\mathrm{B}$ and the higher curvature might prevent the relatively wider cis isomer 6 from entering the hMAO-B binding site. Indeed, 6 has a maximum width of $4.1 \AA$ when measured as the height of the triangle composed of the fluorine atom, one of the $\mathrm{sp}^{2}$ carbons, and the carbon bonded to the nitrogen, while the maximum width of the trans isomer $\mathbf{1}$ is only $2.5 \AA$ when measured as the distance between two opposing carbon atoms in the piperidine ring. The cis isomer thus appears to inhibit hMAO-A but not hMAO-B because it is too wide to enter the narrower hMAO$B$ entrance. Its maximum width is only slightly greater than the $3.8 \AA$ diameter of the hMAO-A entrance, while it is significantly greater than the $3.2 \AA$ diameter of the hMAO-B entrance, which suggests that the hMAO-B entrance would need to undergo more substantial conformational changes to accommodate the cis isomer 6 . The active site loop in hMAOA contains Gly (i.e., Gly110), which is replaced by Pro102 in hMAO-B. This produces much higher rigidity in comparison to hMAO-A, where the active site loop is more flexible. This lack of flexibility of hMAO-B adds to the restricted access of the cis isomer to the hMAO-B active site. The cis isomer 6 inactivity against hMAO-B thus appears to be caused by steric hindrance in the active site, compound 6 being unable to fit into the elongated and rigid cavity (Figure 2).

However, the selectivity of the trans isomer $\mathbf{1}$ is not explained only by the analysis of its access to the active site, as trans isomer 1 can bind to both hMAO-A and hMAO-B. To simulate the transport process of the inhibitor from the active site to the surface of the protein, these two isomers were undocked from hMAO-A and hMAO-B using the CaverDock software. $^{22}$ Starting from the docked conformations of both ligands at the active sites, the energetically most favorable trajectories of the ligands to the protein surfaces were investigated (Figure 3). In hMAO-A, cis isomer 6 is oriented with the propargyl group facing the $\mathrm{FAD}$ cofactor, with a binding energy of $-8.3 \mathrm{kcal} / \mathrm{mol}$ (Figure $3 \mathrm{~A}$, movie file jm9b01886_si_002.mp4 in Supporting Information ). As cis isomer 6 moves toward the entrance, its energy peaks at 0.4 $\mathrm{kcal} / \mathrm{mol}$ and then falls to $-3.8 \mathrm{kcal} / \mathrm{mol}$ at the entrance (Figure 3B). Trans isomer $\mathbf{1}$ in the correct orientation has a binding energy of $-6.2 \mathrm{kcal} / \mathrm{mol}$ (Figure $3 \mathrm{C}$ ), which is higher than for 6. As the trans isomer is undocked, its binding energy peaks at $-3.4 \mathrm{kcal} / \mathrm{mol}$ and then falls to $-4.1 \mathrm{kcal} / \mathrm{mol}$ at the entrance (Figure 3D). Further, the trans ligand in the "wrong" orientation in the active site (i.e., with the fluorophenyl group facing the FAD cofactor) has a much lower energy of -10.1 $\mathrm{kcal} / \mathrm{mol}$ (Figure 3D; lower-bounds energy curve). However, in this orientation, the trans ligand cannot form the covalent bond with FAD. Thus, in agreement with the experimental findings, the computational undocking simulation of hMAO-A showed that cis isomer 6 has lower binding energy at the active site than trans isomer $\mathbf{1}$, which indicates that the cis isomer is more likely to bind to hMAO-A than the trans isomer. In addition, the trans isomer might preferentially access the active site in an orientation that does not allow formation of the covalent bond, as can be seen by the lower binding energy of the "wrong" conformation compared to the energy of the 

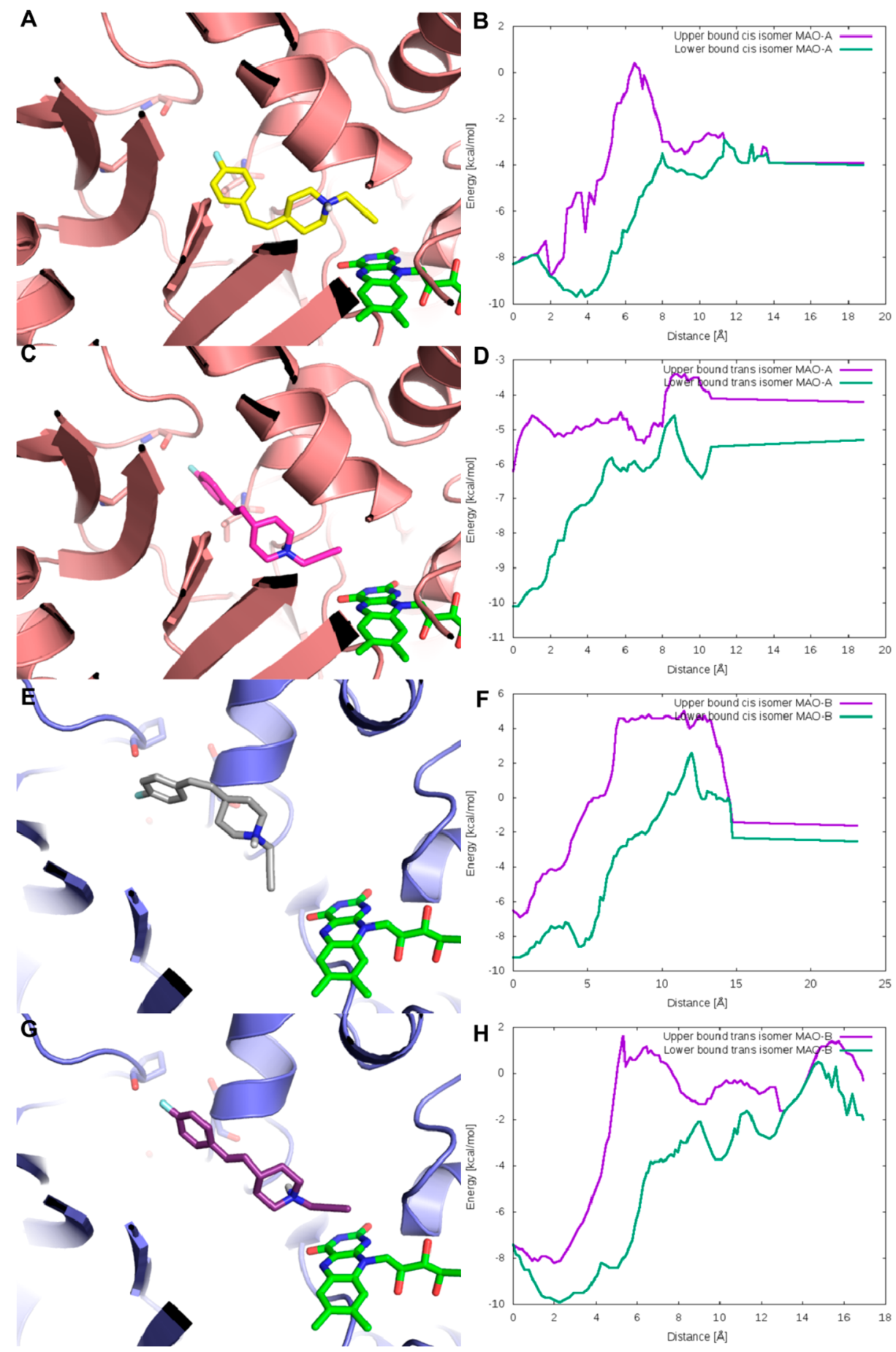

Figure 3. Undocking of trans (1) and cis (6) isomers in hMAO-A and hMAO-B. (A) Docked 6 in hMAO-A: cis isomer (yellow sticks) with propargyl group facing the $\mathrm{FAD}$ cofactor (green sticks), with binding energy of $-8.3 \mathrm{kcal} / \mathrm{mol}$; bottleneck residues at the active site entrance at the back (salmon sticks). (B) Energy profile for undocking of 6 from active site of hMAO-A in the correct conformation (propargyl facing FAD). (C) Docked 1 in hMAO-A: trans isomer (violet sticks) with propargyl group facing the FAD cofactor (green sticks), with binding energy of -6.2 kcal/ mol; bottleneck residues at active site entrance at the back (salmon sticks). (D) Energy profile for undocking of 1 from active site of hMAO-A. (E) Docked 6 in hMAO-B: cis isomer (gray sticks) with propargyl group facing FAD cofactor (green sticks), with binding energy of $-6.5 \mathrm{kcal} / \mathrm{mol}$; bottleneck residues at entrance at the back (violet sticks). (F) Energy profile for undocking of 6 from active site of hMAO-B. (G) Docked 1 in hMAO-B: trans isomer (purple sticks) with propargyl group facing FAD cofactor (green sticks), with binding energy of $-7.4 \mathrm{kcal} / \mathrm{mol}$; bottleneck residues at entrance at the back (violet sticks). (H) Energy profile for undocking of $\mathbf{1}$ from active site of hMAO-B.

correctly oriented trans isomer. This noncovalent only binding of the trans isomer might lead to the worse performance observed experimentally of this inhibitor with hMAO-A.

In hMAO-B, the docked cis ligand 6 in the correct orientation in the active site has energy of $-6.5 \mathrm{kcal} / \mathrm{mol}$
(Figure 3E; movie file jm9b01886_si_003.mp4 in Supporting Information). No energy peaks were observed along the active site for this isomer, whereby the energy reaches a plateau of 4.6 $\mathrm{kcal} / \mathrm{mol}$ near the active site entrance (Figure 3F). Trans isomer $\mathbf{1}$ in the correct orientation has the energy of $-7.4 \mathrm{kcal} /$ 
Scheme 2. Synthesis of Inhibitors $19-26^{a}$

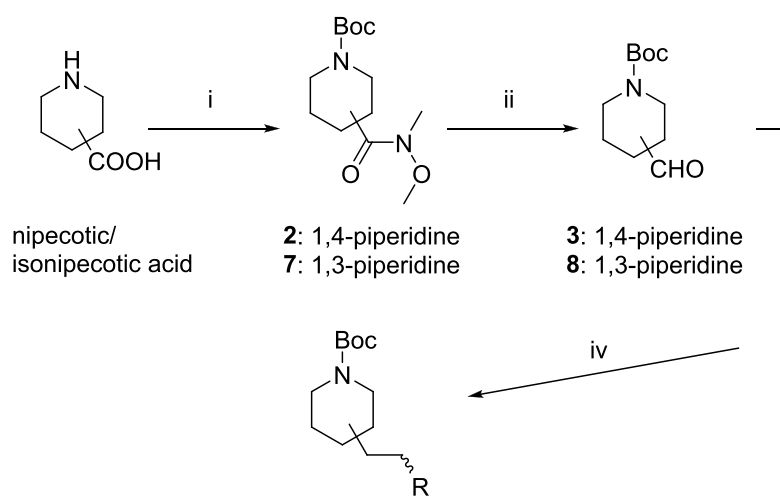

15: 1,3-piperidine, $\mathrm{R}=4-\mathrm{F}-\mathrm{Ph}$

16: 1,3 -piperidine, $R=2,4,5-F-P h$

17: 1,4-piperidine, $\mathrm{R}=4-\mathrm{F}-\mathrm{Ph}$ (from $4 / 5$, Scheme 1 )

18: 1,4 -piperidine, $\mathrm{R}=2,4,5-\mathrm{F}-\mathrm{Ph}$

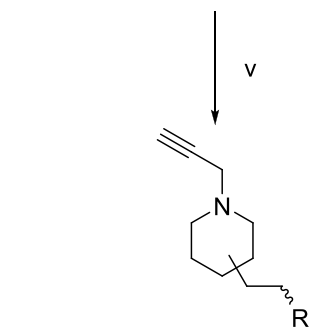

iii

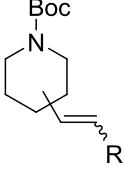

9: 1,3-piperidine, $\mathrm{R}=4-\mathrm{F}-\mathrm{Ph}, \operatorname{cis}(\mathrm{Z})$

10: 1,3-piperidine, $\mathrm{R}=4-\mathrm{F}-\mathrm{Ph}$, trans $(E)$

11: 1,3-piperidine, $R=2,4,5-F-P h, c i s ~(Z)$

12: 1,3-piperidine, $\mathrm{R}=2,4,5-\mathrm{F}-\mathrm{Ph}$, trans $(E)$

13: 1,4-piperidine, $\mathrm{R}=2,4,5-\mathrm{F}-\mathrm{Ph}$, cis $(Z)$

14: 1,4-piperidine, $\mathrm{R}=2,4,5-\mathrm{F}-\mathrm{Ph}$, trans $(E)$

23: 1,3-piperidine, $\mathrm{R}=4-\mathrm{F}-\mathrm{Ph}$

24: 1,3-piperidine, $\mathrm{R}=2,4,5-\mathrm{F}-\mathrm{Ph}$

25: 1,4 -piperidine, $\mathrm{R}=4-\mathrm{F}-\mathrm{Ph}$

26: 1,4-piperidine, $\mathrm{R}=2,4,5-\mathrm{F}-\mathrm{Ph}$

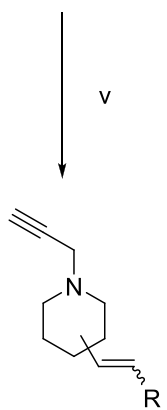

19: 1,3-piperidine, $\mathrm{R}=4-\mathrm{F}-\mathrm{Ph}$, trans $(E)$

20: 1,3-piperidine, $\mathrm{R}=2,4,5-\mathrm{F}-\mathrm{Ph}$, trans $(E)$

21: 1,4-piperidine, $\mathrm{R}=2,4,5-\mathrm{F}-\mathrm{Ph}$, cis $(Z)$

22: 1,4-piperidine, $\mathrm{R}=2,4,5-\mathrm{F}-\mathrm{Ph}$, trans $(E)$

${ }^{a}$ Reagents and conditions: (i) 1) $\mathrm{Boc}_{2} \mathrm{O}, 1.0 \mathrm{M} \mathrm{NaOH}, 1,4$-dioxane, $0{ }^{\circ} \mathrm{C}, \mathrm{rt}, 1-3 \mathrm{~h}(86-91 \%)$; (2) N,O-dimethyhydroxylamine hydrochloride, $\mathrm{Et}_{3} \mathrm{~N}$, TBTU, $\mathrm{CH}_{2} \mathrm{Cl}_{2}, 0{ }^{\circ} \mathrm{C}$ to rt, overnight (76-82\%); (ii) $\mathrm{LiAlH}_{4}$, anh THF, $0{ }^{\circ} \mathrm{C}, 1-2 \mathrm{~h}$ (crude products, 79-83\%); (iii) corresponding Wittig salts ((4-fluorobenzyl)triphenylphosphonium bromide or (2,4,5-trifluorobenzyl)triphenylphosphonium bromide), NaHMDS (2 N in THF), anh THF, $\operatorname{Ar}(\mathrm{g})$, rt, overnight (overall yield for both isomers combined, 47-56\%); (iv) corresponding mixture of cis and trans isomer $(9-14), \mathrm{H}_{2}(\mathrm{~g})$, $\mathrm{Pd} / \mathrm{C}$, EtOH, rt, overnight (97-100\%); (v) (1) $4.0 \mathrm{M} \mathrm{HCl}$ in 1,4-dioxane, $80^{\circ} \mathrm{C}, 2 \mathrm{~h}(100 \%)$; (2) propargyl bromide (80\% solution in toluene), $\mathrm{Cs}_{2} \mathrm{CO}_{3}, \mathrm{DMF}, \mathrm{Ar}(\mathrm{g}), 0{ }^{\circ} \mathrm{C}$, rt, overnight $(26-85 \%)$.

mol (Figure 3G; movie file jm9b01886_si_003.mp4 in Supporting Information), which is lower than the energy of the cis isomer, and then this falls further to $-8.2 \mathrm{kcal} / \mathrm{mol}$ at the lowest point on the way out of the entrance (Figure $3 \mathrm{H}$ ). The energy barrier to reach the active site is lower for the trans isomer than it is for the cis isomer, with the highest peak of 1.5 $\mathrm{kcal} / \mathrm{mol}$ near the entrance, which is lower than the $4.6 \mathrm{kcal} /$ mol energy barrier for the cis isomer. This lower energy barrier of the trans isomer at the entrance might be explained by the smaller maximum width of the trans isomer compared to the cis isomer, as discussed above. We also note that the docked trans inhibitor position in the active site has a root-meansquare deviation of $2.1 \AA$, compared to the cocrystal structure of inhibitor 1 in hMAO-B reported in the present study (PDB code $6 \mathrm{RKB})$. This indicates that the docking successfully predicted the positioning of this inhibitor in the active site. In agreement with the experimental findings, the lower binding energies at the active site for the trans isomer and the lower energy barrier to reach the active site for the trans isomer indicate that the binding of trans isomer 1 to hMAO-B is favored compared to the binding of cis isomer $\mathbf{6}$.

The distinct activity of this geometric isomer pair prompted us to study the structure-activity relationships (SARs) through the construction of a focused library of substituted piperidines (19-26; Scheme 2, Table 1) to probe the effect of piperidine disubstitution pattern on the inhibitory potency.
1,4-Disubstituted piperidines were the most tolerated and showed the highest selectivity for both hMAO-A and hMAO$B$, and thus several analogues with various substituents on the phenyl ring were synthesized (Scheme 3, compounds 67107).

Structure-Activity Relationships and Stability of Compounds. Hit inhibitor 1 and the synthesized analogues 6, 19-26, and 67-107 were evaluated for their inhibition of both hMAO-A and hMAO-B using a horseradish peroxidase (HRP)-Amplex Red coupled assay (Table 1). The most important findings regarding the SARs are summarized in Figure 4. Scanning the 1,3- and 1,4-disubstitution patterns of piperidine derivatives with the trans configuration of the double bond revealed at least 5-fold superior inhibition of hMAO-B for the 1,4-disubstitution (e.g., $19 \mathrm{IC}_{50}=1470 \mathrm{nM}$ vs $1 \mathrm{IC}_{50}=342 \mathrm{nM}$ ). Interestingly, reduction of the double bond retained this selective hMAO-B inhibition $\left(\mathrm{IC}_{50}\right.$ of $243 \mathrm{nM}$ and $370 \mathrm{nM}$ for hit compound 1 and analogue 25, respectively. Broadening the series of 1,4-disubsituted piperidines showcased selective inhibition of hMAO-A by cis analogues with small substituents on the phenyl ring (e.g., fluorine). The most potent was 69, a 3-fluorophenyl derivative, with an $\mathrm{IC}_{50}$ of 68.4 $\mathrm{nM}$ and almost a 3-log unit selectivity over hMAO-B. On the other hand, the trans derivatives preferentially inhibited hMAO-B, with a general trend of improved inhibitory potencies with increasing hydrophobicity/size of the sub- 
Table 1. Inhibitory Potencies and Structures of Hit Compound 1 and All of the Synthesized Inhibitors and Positive Controls ${ }^{a}$

\begin{tabular}{|c|c|c|c|c|c|c|}
\hline \multirow[b]{2}{*}{ compd } & \multicolumn{3}{|c|}{ structure } & \multicolumn{2}{|c|}{$\mathrm{IC}_{50} \pm \mathrm{SEM}[\mathrm{nM}]$ or $\% \mathrm{RA} \pm \mathrm{SD}$ at $100 \mu \mathrm{M}$} & \multirow[b]{2}{*}{ selectivity ratio ${ }^{c}$} \\
\hline & $\mathrm{Pdp}^{b}$ & linker & $\mathrm{R}$ & hMAO-A & hMAO-B & \\
\hline 1 & 1,4 & trans-vinyl & $4-\mathrm{F}$ & $60.2 \pm 1.6 \%$ & $342.2 \pm 22.4$ & $>292$ \\
\hline 6 & 1,4 & cis-vinyl & $4-\mathrm{F}$ & $726.1 \pm 26.9$ & $6221.5 \pm 726.8$ & 0.12 \\
\hline 25 & 1,4 & ethyl & $4-\mathrm{F}$ & $76.9 \pm 2.2 \%$ & $370.1 \pm 37.3$ & $>270$ \\
\hline 21 & 1,4 & cis-vinyl & $2,4,5-\mathrm{F}$ & $5243.7 \pm 323.4$ & $66.5 \pm 3.9 \%$ & $<0.05$ \\
\hline 22 & 1,4 & trans-vinyl & $2,4,5-\mathrm{F}$ & $81.2 \pm 3.1 \%$ & $436.2 \pm 11.7$ & $>229$ \\
\hline 26 & 1,4 & ethyl & $2,4,5-\mathrm{F}$ & $65.6 \pm 4.4 \%$ & $216.4 \pm 14.2$ & $>462$ \\
\hline 19 & 1,3 & trans-vinyl & $4-\mathrm{F}$ & $91.0 \pm 3.1 \%$ & $1469.5 \pm 233.2$ & $>68$ \\
\hline 23 & 1,3 & ethyl & $4-\mathrm{F}$ & $93.1 \pm 3.2 \%$ & $7411.6 \pm 1190.0$ & $>13$ \\
\hline 20 & 1,3 & trans-vinyl & $2,4,5-F$ & $102.5 \pm 5.2 \%$ & $2195.6 \pm 228.3$ & $>46$ \\
\hline 24 & 1,3 & ethyl & $2,4,5-F$ & $86.0 \pm 5.2 \%$ & $11229.4 \pm 974.7$ & $>9$ \\
\hline 67 & 1,4 & cis-vinyl & $\mathrm{H}$ & $168.8 \pm 8.5$ & $79.1 \pm 4.0 \%$ & $<0.002$ \\
\hline 68 & 1,4 & trans-vinyl & $\mathrm{H}$ & $32960.7 \pm 3476.5$ & $3540.2 \pm 611.8$ & 9 \\
\hline 93 & 1,4 & ethyl & $\mathrm{H}$ & $75779.6 \pm 7566.0^{d}$ & $4603.4 \pm 371.1$ & 16 \\
\hline 69 & 1,4 & cis-vinyl & $3-\mathrm{F}$ & $68.4 \pm 4.3$ & $48912.0 \pm 2525.4$ & 0.001 \\
\hline 70 & 1,4 & trans-vinyl & $3-\mathrm{F}$ & $6906.8 \pm 860.2$ & $5048.7 \pm 1224.6$ & 1.4 \\
\hline 94 & 1,4 & ethyl & $3-\mathrm{F}$ & $19927.3 \pm 1608.5$ & $3363.5 \pm 310.5$ & 6 \\
\hline 71 & 1,4 & cis-vinyl & $2-\mathrm{F}$ & $3013.7 \pm 207.3$ & $65.5 \pm 0.3 \%$ & $<0.03$ \\
\hline 72 & 1,4 & trans-vinyl & $2-\mathrm{F}$ & $27293.2 \pm 1758.4$ & $11830.4 \pm 766.5$ & 2 \\
\hline 95 & 1,4 & ethyl & $2-\mathrm{F}$ & $5927.3 \pm 223.8$ & $14159.5 \pm 708.9$ & 0.4 \\
\hline 73 & 1,4 & cis-vinyl & 2-Cl-4-F & $46121.5 \pm 10141.6$ & $53000.5 \pm 2662.5$ & 0.9 \\
\hline 74 & 1,4 & trans-vinyl & $2-\mathrm{Cl}-4-\mathrm{F}$ & $66028.4 \pm 8419.0$ & $417.6 \pm 46.9$ & 158 \\
\hline 75 & 1,4 & cis-vinyl & 4-Me & $62.2 \pm 4.4 \%$ & $19162.8 \pm 5139.7$ & $>5$ \\
\hline 76 & 1,4 & trans-vinyl & 4-Me & $57.3 \pm 2.9 \%$ & $147.0 \pm 13.8$ & $>680$ \\
\hline 96 & 1,4 & ethyl & 4-Me & $68.1 \pm 1.6 \%$ & $159.0 \pm 13.3$ & $>630$ \\
\hline 77 & 1,4 & cis-vinyl & 4-iPr & $83.2 \pm 0.5 \%$ & $1883.9 \pm 278.6$ & $>53$ \\
\hline 78 & 1,4 & trans-vinyl & 4-iPr & $73638.2 \pm 11010.1^{d}$ & $44.4 \pm 8.2$ & 1658 \\
\hline 97 & 1,4 & ethyl & 4-iPr & $162399.3 \pm 9715.9^{d}$ & $7.0 \pm 2.2$ & 23200 \\
\hline 79 & 1,4 & cis-vinyl & $4-\mathrm{Cl}$ & $118844.3 \pm 26412.7^{d}$ & $11745.1 \pm 555.9$ & 10 \\
\hline 80 & 1,4 & trans-vinyl & $4-\mathrm{Cl}$ & $71.7 \pm 0.2 \%$ & $50.4 \pm 4.7$ & $>1984$ \\
\hline 98 & 1,4 & ethyl & $4-\mathrm{Cl}$ & $67.7 \pm 0.0 \%$ & $38.1 \pm 6.8$ & $>2625$ \\
\hline 81 & 1,4 & trans-vinyl & $4-\mathrm{Br}$ & $54.5 \pm 1.2 \%$ & $21.2 \pm 4.2$ & $>4717$ \\
\hline 82 & 1,4 & trans-vinyl & 4-OMe & $56.1 \pm 1.6 \%$ & $68.1 \pm 11.1$ & $>1468$ \\
\hline 99 & 1,4 & ethyl & 4-OMe & $62.2 \pm 1.9 \%$ & $67.0 \pm 11.4$ & $>1493$ \\
\hline 83 & 1,4 & cis-vinyl & $4-\mathrm{CF}_{3}$ & $80.1 \pm 4.5 \%$ & $1506.6 \pm 216.3$ & $>66$ \\
\hline 84 & 1,4 & trans-vinyl & $4-\mathrm{CF}_{3}$ & $64.9 \pm 0.5 \%$ & $18.6 \pm 3.3$ & $>5376$ \\
\hline 100 & 1,4 & ethyl & $4-\mathrm{CF}_{3}$ & $62.3 \pm 0.7 \%$ & $10.9 \pm 3.0$ & $>9174$ \\
\hline 85 & 1,4 & cis-vinyl & $3-\mathrm{CF}_{3}$ & $858.0 \pm 29.2$ & $9352.5 \pm 1512.9$ & 0.09 \\
\hline 86 & 1,4 & trans-vinyl & $3-\mathrm{CF}_{3}$ & $64.8 \pm 4.0 \%$ & $549.7 \pm 127.5$ & $>182$ \\
\hline 101 & 1,4 & ethyl & $3-\mathrm{CF}_{3}$ & $71.6 \pm 2.2 \%$ & $501.8 \pm 107.1$ & $>199$ \\
\hline 87 & 1,4 & cis-vinyl & $4-\mathrm{CN}$ & $68.1 \pm 2.7 \%$ & $1745.3 \pm 315.4$ & $>57$ \\
\hline 88 & 1,4 & trans-vinyl & 4-CN & $129064.0 \pm 8079.7^{d}$ & $57.0 \pm 7.1$ & 2264 \\
\hline 102 & 1,4 & ethyl & $4-\mathrm{CN}$ & $21478.3 \pm 6280.3$ & $56.6 \pm 8.7$ & 379 \\
\hline 89 & 1,4 & cis-vinyl & $4-\mathrm{SO}_{2} \mathrm{Me}$ & $70.6 \pm 5.8 \%$ & $8444.7 \pm 627.1$ & $>12$ \\
\hline 90 & 1,4 & trans-vinyl & $4-\mathrm{SO}_{2} \mathrm{Me}$ & $68.7 \pm 0.2 \%$ & $32.7 \pm 2.5$ & $>3058$ \\
\hline 91 & 1,4 & cis-vinyl & 4-cyclopropyl & $7398.7 \pm 661.8$ & $2640.1 \pm 342.8$ & 3 \\
\hline 92 & 1,4 & trans-vinyl & 4-cyclopropyl & $20564.5 \pm 2315.8$ & $43.7 \pm 6.4$ & 471 \\
\hline 103 & 1,4 & ethyl & 4-propyl & $80305.3 \pm 9033.0$ & $36.1 \pm 4.1$ & 2225 \\
\hline 104 & 1,4 & cis-vinyl & 4- $\mathrm{CONH}_{2}$ & $89.5 \pm 0.6 \%$ & $51019.0 \pm 6046.5$ & 2 \\
\hline 105 & 1,4 & trans-vinyl & 4- $\mathrm{CONH}_{2}$ & $64.8 \pm 1.1 \%$ & $1737.0 \pm 691.0$ & 58 \\
\hline 106 & 1,4 & ethyl & $4-\mathrm{CONH}_{2}$ & $75.1 \pm 2.2 \%$ & $5554.5 \pm 1778.9$ & $>18$ \\
\hline 107 & 1,4 & ethyl & $4-\mathrm{OH}$ & $67.7 \pm 0.5 \%$ & $7440.7 \pm 1291.3$ & $>13$ \\
\hline
\end{tabular}


Table 1. continued

\begin{tabular}{|c|c|c|c|c|c|c|}
\hline \multirow[b]{2}{*}{ compd } & \multicolumn{3}{|c|}{ structure } & \multicolumn{2}{|c|}{$\mathrm{IC}_{50} \pm \mathrm{SEM}[\mathrm{nM}]$ or $\% \mathrm{RA} \pm \mathrm{SD}$ at $100 \mu \mathrm{M}$} & \multirow[b]{2}{*}{ selectivity ratio ${ }^{c}$} \\
\hline & $\operatorname{Pdp}^{b}$ & linker & $\mathrm{R}$ & hMAO-A & hMAO-B & \\
\hline pargyline & & & & $3967.9 \pm 275.1$ & $195.5 \pm 19.1$ & 20 \\
\hline L-deprenyl & & & & $62663.8 \pm 4113.6$ & $12.1 \pm 4.2$ & 5179 \\
\hline rasagiline & & & & $29520 \pm 8597$ & $36.0 \pm 4.1$ & 820 \\
\hline clorgiline & & & & $3.4 \pm 0.3$ & $13568.4 \pm 1157.3$ & 0.0003 \\
\hline
\end{tabular}

${ }^{a}$ Data are mean values \pm SEM: $\mathrm{IC}_{50}$ (in boldface), $n=2,3$; residual activity (RA), $n=2 .{ }^{b} \mathrm{Pdn}$ : piperidine disubstitution pattern. ${ }^{c}$ Selectivity ratio is defined as $\mathrm{IC}_{50}(\mathrm{hMAO}-\mathrm{A}) / \mathrm{IC}_{50}(\mathrm{hMAO}-\mathrm{B}) .{ }^{d}$ Estimated $\mathrm{IC}_{50}$ values from the RAs below $100 \mu \mathrm{M}$. Compounds showed precipitation in the assay buffer at concentrations above $100 \mu \mathrm{M}$.

Scheme 3. Synthesis of Inhibitors $67-107^{a}$

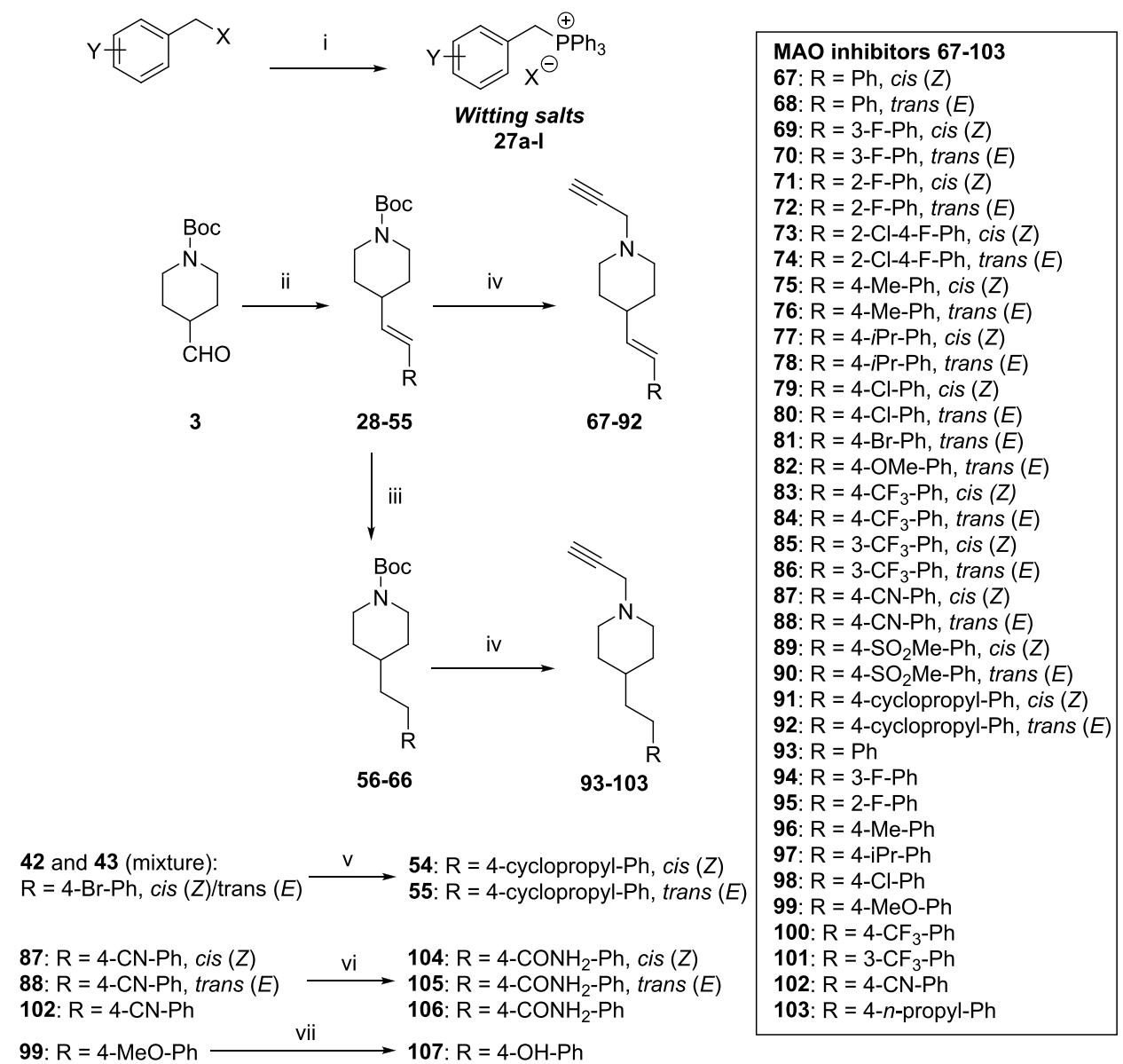

${ }^{a}$ Reagents and conditions: (i) benzyl halide, $\mathrm{PPh}_{3}, \mathrm{MeCN}, 85^{\circ} \mathrm{C}$, overnight (80-97\%); (ii) corresponding Wittig salts (27a-1), NaHMDS (2 N in THF)/KHMDS (0.5 M in toluene), anh THF, $\operatorname{Ar}(\mathrm{g})$, rt, overnight (overall yield, 30-66\%); (iii) mixture of cis and trans isomers $(\mathbf{2 8}-\mathbf{5 5}), \mathrm{H}_{2}(\mathrm{~g})$, $\mathrm{Pd} / \mathrm{C}$, EtOH, rt, overnight (83-100\%); (iv) (1) $4.0 \mathrm{M} \mathrm{HCl}$ in 1,4-dioxane (or $\mathrm{HCl}$ in EtOH), $80{ }^{\circ} \mathrm{C}, 2 \mathrm{~h}(100 \%$ ); (2) propargyl bromide (80\% in toluene), $\mathrm{K}_{2} \mathrm{CO}_{3}, \mathrm{MeCN}, \operatorname{Ar}(\mathrm{g}), 0{ }^{\circ} \mathrm{C}$, rt, overnight (6-89\%); (v) cyclopropylboronic acid, $\mathrm{K}_{3} \mathrm{PO}_{4}$, tricyclohexylphosphine (20\% in toluene),

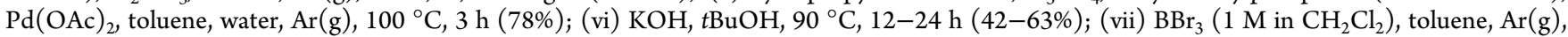
$-20{ }^{\circ} \mathrm{C}, 1 \mathrm{~h}, \mathrm{rt}, 1 \mathrm{~h}(57 \%)$.

stituents on phenyl ring position $4(-\mathrm{H}<-\mathrm{F}<-\mathrm{Cl}<-\mathrm{Br}$ and $-\mathrm{H}<-\mathrm{Me}<-i \operatorname{Pr} \sim-$ cyclopropyl). Double-digit nanomolar inhibition of hMAO-B was also obtained for 82, 84, 88, and 90 with $-\mathrm{OMe},-\mathrm{CF}_{3},-\mathrm{CN},-\mathrm{SO}_{2} \mathrm{Me}$ substituents, respectively, on position 4 of the phenyl ring. Compounds with an ethyl moiety that connected the rings showed comparable selective inhibition of hMAO-B as their trans congeners. All the $\mathrm{N}$-propargylpiperidine derivatives inhibited corresponding isoenzyme in an irreversible manner as demonstrated by the 100 -fold dilution assay.
For additional experiments, compounds 1, 6, 67, 69, 84, 97, and $\mathbf{1 0 0}$ were used in the form of hydrochloride salts to avoid possible solubility issues. The thermodynamic solubility of the compounds in PBS ( $\mathrm{pH} 7.4$ ) was at least $17.6 \mathrm{~g} / 250 \mathrm{~mL}, 10.5$ $\mathrm{g} / 250 \mathrm{~mL}, 8.6 \mathrm{~g} / 250 \mathrm{~mL}, 12.5 \mathrm{~g} / 250 \mathrm{~mL}, 14.5 \mathrm{~g} / 250 \mathrm{~mL}$, and $16.3 \mathrm{~g} / 250 \mathrm{~mL}$ for $6,67,69,84,97$, and 100 , respectively, which is good solubility according to biopharmaceutical classification for any realistically expected dose of investigated compounds.

Possible chemical instability and photoisomerization of $E / Z$ isomers were also addressed as these are known liabilities of 


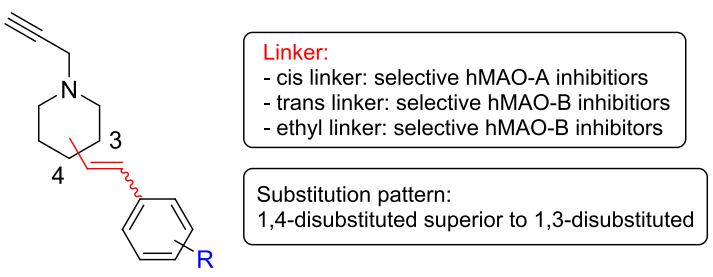

$\mathrm{R}:$

$-\mathrm{H}, \mathrm{F}$ or $3-\mathrm{CF}_{3}$ tolerated for selective $\mathrm{hMAO}-\mathrm{A}$ inhibition in cis derivatives - position 4: $\mathrm{Cl}, \mathrm{Br}, \mathrm{Me}, \mathrm{OMe}_{\mathrm{CN}} \mathrm{CF}_{3}$, iPr tolerated in selective hMAO-B inhibitors

Figure 4. Crucial observations regarding SARs of the stilbene-like $\mathrm{MAO}$ inhibitors.

stilbene derivatives. ${ }^{23}$ Proton NMRs of 69 (cis derivative), 84 (trans derivative), and $\mathbf{1 0 0}$ (ethyl analogue) in the form of hydrochloride salts were recorded in $\mathrm{D}_{2} \mathrm{O}$ (Figures $\mathrm{S} 1-\mathrm{S} 3$ ). Inspection of the spectra confirmed that these compounds are relatively stable after more than 1 year of storage at room temperature (protected from sunlight) as only smaller amounts of impurities were detected for 84 (in the aromatic area), whereas compounds 69 and 100 showed no signs of chemical instability. The samples dissolved in the NMR tubes were then left on the benchtop exposed to natural daylight for 7 days, which could induce photoisomerization. No spectral changes were observed in comparison to spectra of freshly prepared samples. Altogether, these studies imply reasonable stability of the compounds.

Kinetic Evaluation. The exploration of SARs allowed the identification of a few compounds for more in-depth kinetic analysis with the purified enzyme samples, which allowed their inhibition mechanism to be better defined. On the basis of their inhibitory potencies and molecular features, compounds 1, 84, and 97 were selected for hMAO-B, whereas for hMAOA the analysis was restricted to 69 . The inhibitors were tested using UV-vis spectrum measurements (Figure 5) and steadystate enzymatic assays (Table 2). The propargyl unit is known to react covalently with the N5 atom of the flavin cofactor by rapidly forming a stable covalent adduct that produces a typical modification of the spectrum; this is seen as bleaching of the peak at $450 \mathrm{~nm}$ and appearance of a stronger peak at $415 \mathrm{~nm} .^{24}$ All of these selected compounds were tested by adding them in 10 -fold excess to the protein solution in the spectrophotometer cuvette and measuring the spectra over time until no further modification was detected. All of the irreversible inhibitors produced a clear change in the enzyme spectra (Figure 5), similar to other classic acetylenic inhibitors, like L-deprenyl and clorgyline. ${ }^{24}$ However, there were differences in the times required to complete the reactions for the adduct formation, i.e., to reach the final spectrum with no further modification. While 69 fully inactivated hMAO-A almost instantaneously (Figure 5A), similar to clorgyline, the hMAO-B selective compounds were slower. In particular, 84 initiated the reaction with the flavin within $1 \mathrm{~min}$, showing an intermediate spectrum profile that evolved into the final $415 \mathrm{~nm}$ peak in $30 \mathrm{~min}$ (Figure 5B). Instead, $\mathbf{1}$ and 97 did not show any spectral modifications in the first few minutes and required half an hour to obtain an intermediate profile and more than $2 \mathrm{~h}$ to complete the reaction (Figure 5C and Figure 5D, respectively).

Full kinetic analysis was then undertaken for hMAO-A and hMAO-B inhibition by the selected compounds, using purified enzyme samples and the spectrophotometric version of the assay coupled to HRP that was used for $\mathrm{IC}_{50}$ determination, as described above. As enzyme inhibition by propargyl-based
A

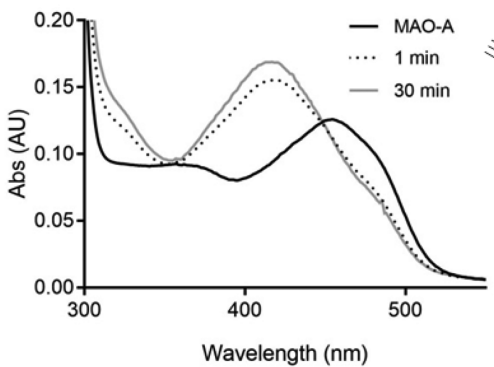

C

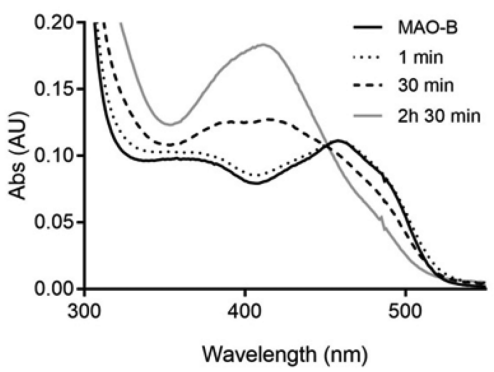

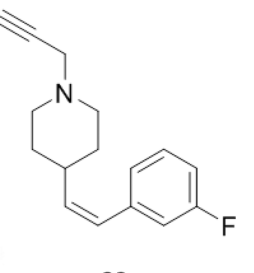

69

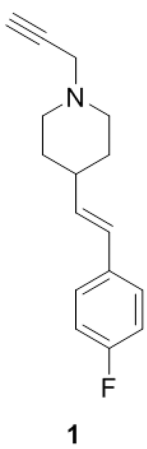

B
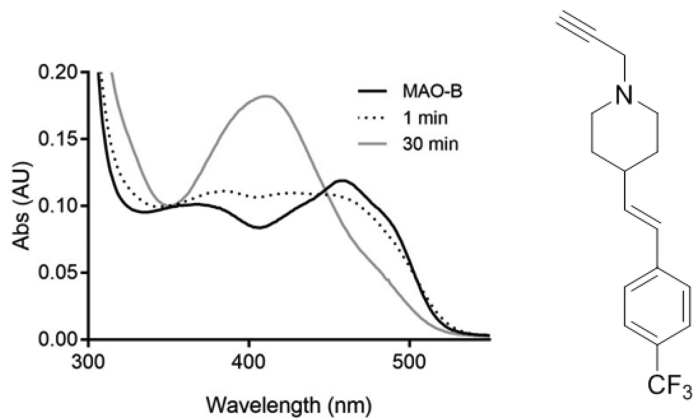

D

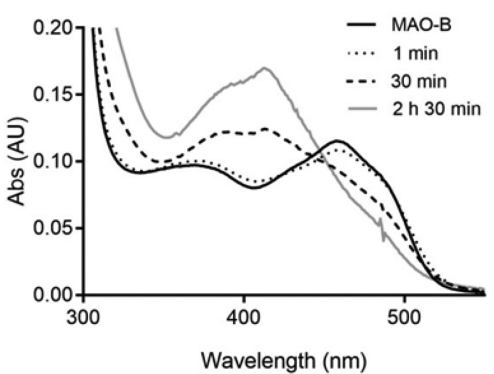

84

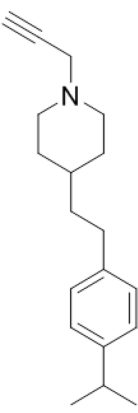

97

Figure 5. UV-vis absorption spectra of the hMAO enzymes after FAD cofactor modification by irreversible covalent inhibitors. The oxidized enzyme $(10 \mu \mathrm{M})$ before inhibitor addition $(100 \mu \mathrm{M})$ is shown as the continuous black line, whereas the gray profile indicates the final spectrum (i.e., no further changes were observed), which was reached at different times depending on the inhibitor. The intermediate spectra are shown as either dotted or dashed lines. (A) hMAO-A and 69; (B) hMAO-B and 84; (C) hMAO-B and 1; (D) hMAO-B and 97. 
Table 2. Kinetic Parameters for the Reversible and Irreversible Inhibition of the hMAOs by the Selected 4-Styrylpiperidine Inhibitors

\begin{tabular}{|c|c|c|c|c|c|}
\hline \multirow[b]{2}{*}{ MAO } & \multirow[b]{2}{*}{ inhibitor } & \multirow{2}{*}{$\frac{\text { reversible inhibition }}{K_{\mathrm{i}}(\mu \mathrm{M})}$} & \multicolumn{2}{|c|}{ irreversible inhibition } & \multirow[b]{2}{*}{$k_{\text {inact }} / K_{\mathrm{I}}\left(\min ^{-1} \mu \mathrm{M}^{-1}\right)$} \\
\hline & & & $K_{\mathrm{I}}(\mu \mathrm{M})$ & $k_{\text {inact }}\left(\min ^{-1}\right)$ & \\
\hline \multirow[t]{2}{*}{ hMAO-A } & 69 & $0.23 \pm 0.02$ & $1.01 \pm 0.76$ & $1.25 \pm 0.25$ & 1.24 \\
\hline & clorgyline $^{a}$ & $0.040 \pm 0.004^{b}$ & $0.22 \pm 0.08^{b}$ & $0.12 \pm 0.05^{b}$ & $0.55^{b}$ \\
\hline \multirow[t]{4}{*}{ hMAO-B } & 1 & $1.92 \pm 0.32$ & $1.38 \pm 0.29$ & $0.66 \pm 0.04$ & 0.48 \\
\hline & 84 & $1.25 \pm 0.23$ & $17.25 \pm 4.38$ & $2.03 \pm 0.38$ & 0.12 \\
\hline & 97 & $1.36 \pm 0.31$ & $6.55 \pm 1.62$ & $1.04 \pm 0.12$ & 0.16 \\
\hline & L-deprenyl $^{a}$ & $0.97 \pm 0.11$ & $5.68 \pm 0.78$ & $2.56 \pm 0.24$ & 0.45 \\
\hline
\end{tabular}

${ }^{a}$ Kinetic parameters were compared to clorgyline and L-deprenyl in the cases of hMAO-A and hMAO-B selective inhibitors, respectively. ${ }^{b}$ Data from Esteban et al. (2014). ${ }^{25}$
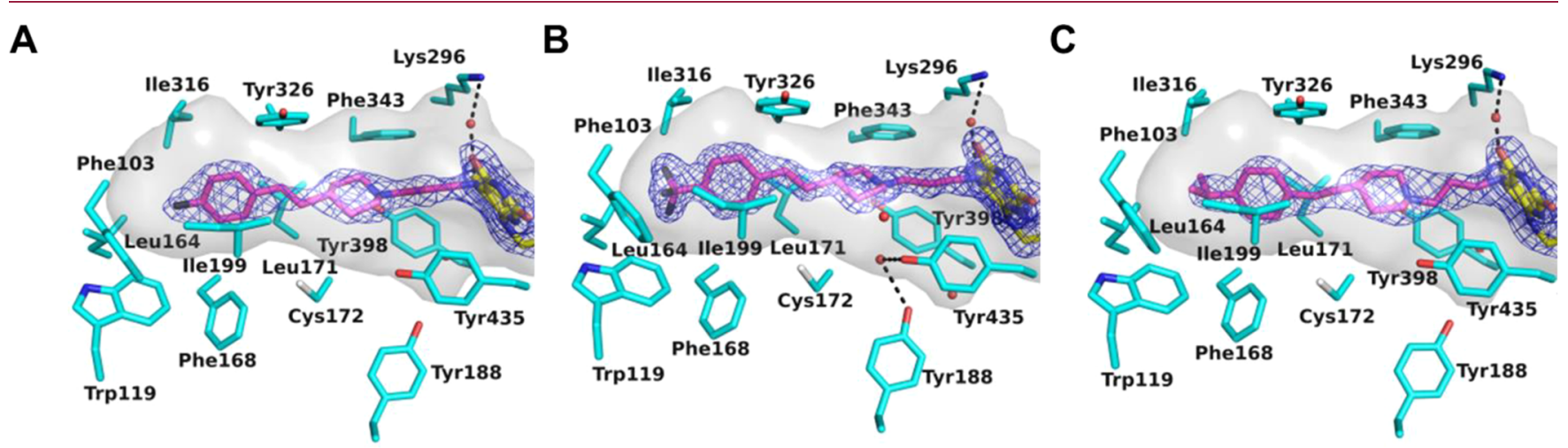

Figure 6. Crystal structures of the active site of hMAO-B-inhibitor complexes. The hMAO-B active site cavity is shown as a gray semitransparent surface, which is lined by the protein residues (represented in cyan). Water molecules are red spheres, and hydrogen bonds are dashed lines. The FAD cofactor is in yellow stick representation. The inhibitor molecule bound in the hMAO-B active site cavity is shown as sticks, with carbon, nitrogen, and fluorine in magenta, blue, and black, respectively. The refined $2 F_{\mathrm{o}}-F_{\mathrm{c}}$ electron density map contoured at $1.2 \sigma$ is shown in blue for the inhibitor and the FAD molecules. (A) Active site of hMAO-B in complex with 1 (2.3 Å resolution; PDB code 6RKB). (B) Active site of hMAO$\mathrm{B}$ in complex with 84 (1.7 Å resolution; PDB code 6RKP). (C) Active site of hMAO-B in complex with 97 (2.3 $\AA$ resolution; PDB code 6RLE).
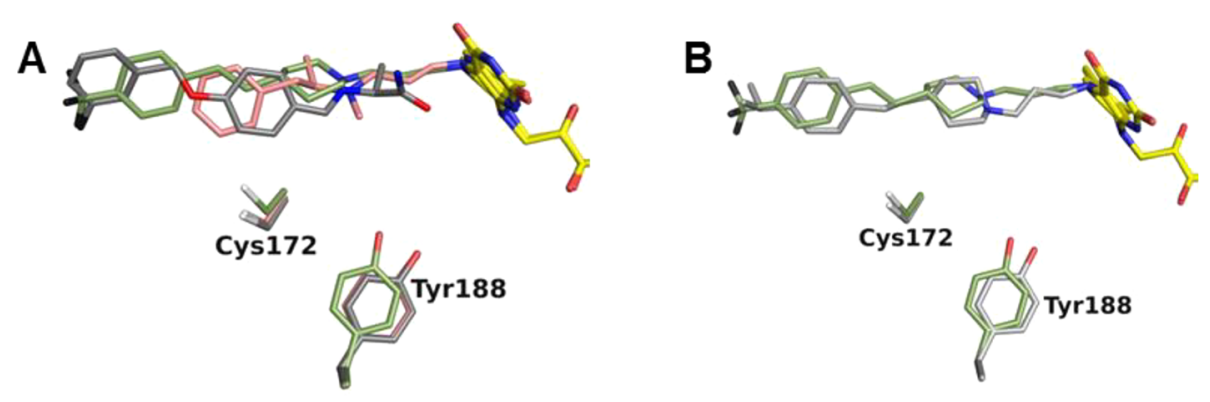

Figure 7. Structural superposition to highlight differences and common features in the binding modes of the hMAO-B inhibitors. The protein, inhibitor, and cofactor atoms are represented as sticks (color code as in Figure 6 except for the carbon atoms of protein and inhibitor molecules, which are depicted accordingly to distinguish the different structures). For clarity, only Cys172 and Tyr188 of the protein active site residues are shown, which undergo some conformational changes. (A) Superposition of structures in complex with 84 (green), safinamide (gray) and Ldeprenyl (pink). (B) Superposition of structures in complex with 84 (green) and $\mathbf{9 7}$ (light gray).

inhibitors involves a first step in which the ligand is accommodated into the protein active site to be correctly oriented for flavin adduct formation, competitive inhibition can be measured under steady-state conditions using kynuramine and benzylamine as substrates for hMAO-A and hMAO-B, respectively. Thus, both the reversible and irreversible inhibition parameters were determined (Table 2). Compound 69 is a potent hMAO-A inhibitor with a reversible $K_{\mathrm{i}}$ of 0.23 $\mu \mathrm{M}$, which is 5-fold higher than that reported for clorgyline. This difference is in line with the irreversible constant $K_{\mathrm{I}}$, and it is balanced by the irreversible inactivation velocity that is 10 fold higher that for clorgyline. Overall, 69 is a very potent
hMAO-A inhibitor with comparable activity to clorgyline. Similar to L-deprenyl, in the case of hMAO-B selective ligands, the reversible $K_{\mathrm{i}}$ values are all in the micromolar range. The irreversible constant $K_{\mathrm{I}}$ for covalent hMAO-B inhibitors is in general 5-fold the reversible $K_{\mathrm{i}}$; however, the $k_{\text {inact }} / K_{\mathrm{I}}$ indicated comparable inhibitory potencies of the hMAO-B inhibitors to L-deprenyl.

Structure of hMAO-B in Complex with Inhibitors. Structural studies were performed by cocrystallization of hMAO-B with the inhibitors selected for the kinetic analyses, using previously published procedures. ${ }^{26}$ Structures for inhibitors 1, 84, and 97 were solved at resolution ranging 


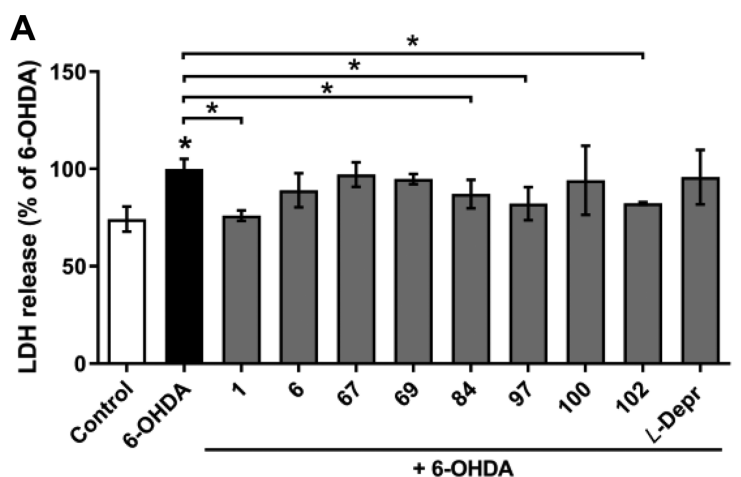

B

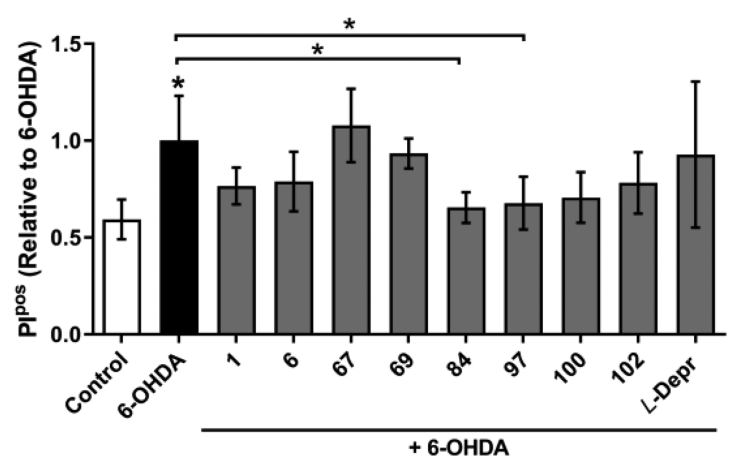

Figure 8. Effects of inhibitors on 6-OHDA-induced cell death in SH-SY5Y cells. (A, B) SH-SY5Y cells were pretreated with the compounds ( $5 \mu$ M) for $30 \mathrm{~min}$ (as indicated) and then treated with 6-OHDA $(100 \mu \mathrm{M})$. After $24 \mathrm{~h}, \mathrm{LDH}$ assays (A) and PI staining (B) were performed. Data are mean values \pm standard deviation $(n \geq 2$; each in duplicate): $*, p<0.05$ (one-way ANOVA, with Bonferroni correction, followed by $t$-tests).

from 2.3 to $1.7 \AA$ (Figure 6). The crystallographic statistics are reported in Table S1. Crystallographic studies on hMAO-B in complex with 1, 84, and 97 showed that these inhibitor molecules are certain to be bound to the enzyme active site (Figure 6). Ligand binding does not cause any major conformational changes to the overall protein dimeric structure (Figure S4). As for all of the inhibitors, the structure of the active site is identical in the two monomers present in the asymmetric unit that forms the protein dimer, and here we will refer to chain A of each structure in the following discussion. The electron density map clearly showed that all of these inhibitors form a covalent adduct with the flavin (Figure 6).

All of these inhibitors bind to the hMAO-B active site in a similar fashion, from the covalent adduct with the flavin to the 4-substituted phenyl ring at the other end of the molecule (Figure 6). They adopt an extended conformation, as they occupy both the substrate and the cavity spaces (Ile199 in the open conformation). The 4-substituted phenyl ring is constrained by the flat hydrophobic shape of the hMAO-B cavity in a position perpendicular to the flavin plane, as for other wellknown inhibitors, such as L-deprenyl and safinamide (Figure $7 \mathrm{~A})$. The site occupied by the halogen substituent on the aromatic ring of $\mathbf{1}$ is also conserved, which is a common feature of many hMAO-B inhibitors. ${ }^{27}$ The more polar substituents that have lower inhibitory activities (e.g., 82, 105) would be much less favored in their binding to this highly hydrophobic site. The enzyme active site architecture does not undergo any conformational change with respect to that of other hMAO-B structures except for minor modifications to the side chains of Cys172 and Tyr188 (Figure 7A). This is due to the position adopted by the piperidine ring that represents the hallmark of this series of inhibitors. Despite the flat shape of the hMAO-B cavity, the nonplanar conformation of the piperidine and its pyramidal nitrogen that is involved in the covalent adduct constrain the piperidine ring to bind perpendicular to the plane of the cavity (Figure 6). Instead, with other inhibitors such as L-deprenyl and safinamide, there is an aromatic ring that binds coplanar with the cavity plane and with any substituted aromatic at the other end of the molecule, if present (Figure $7 \mathrm{~A})$. Therefore, the position of the piperidine in the upper part of the cavity allows Cys172 and Tyr188 to move slightly upward. In the structure of the complex with 97, the conformation of the Cys172 and Tyr188 is conserved to some extent with respect to the previous structures. This is due to the linker that is devoid of the double bond, and the consequent tetrahedral conformation of its carbon atoms results in a more contracted conformation of the inhibitor molecule with respect to $\mathbf{8 4}$ (Figure $7 \mathrm{~B}$ ) and $\mathbf{1}$. As a result, the piperidine collapses toward the bottom of the cavity, and the covalent linkage is forced to adopt a slightly different conformation with respect to the other propargyl inhibitors (Figure 7).

Cell-Based Assays. Following the chemical-space exploration and kinetic and structural evaluations, several of these structurally diverse hMAO-A and hMAO-B inhibitors were also tested in vitro in cell models. First, their cytotoxicity profiles were defined using the SH-SY5Y human neuroblastoma cell line. By use of the MTS assay, no significant cytotoxic effects were seen for $24 \mathrm{~h}$ treatments of these cells with the compounds $1,6,67,69,84,97,100$, and 102 at concentrations of $5 \mu \mathrm{M}$ and $10 \mu \mathrm{M}$ (Figure S5). Indeed, at 50 $\mu \mathrm{M}$, the cell viabilities remained $>80 \%$ for almost all of the compounds, which is roughly $3 \mathrm{log}$ units higher than the concentrations needed to achieve $50 \%$ in vitro inhibition of either of the two MAO isoforms.

The experimental in vitro cell model with the neurotoxin 6hydroxydopamine (6-OHDA) is commonly used to study neurodegenerative processes, as it induces toxicity that mimics the biochemistry and neuropathology of Parkinson's disease. ${ }^{28}$ To determine the possibility that MAO inhibitors can abrogate 6-OHDA-induced toxicity, we examined lactate dehydrogenase (LDH) release and propidium iodide (PI) staining in the SHSY5Y cells after 30 min pretreatment with the compounds at the noncytotoxic concentration of $5 \mu \mathrm{M}$, followed by 6-OHDA treatment for $24 \mathrm{~h}$ (Figure 8). The active treatment with 6OHDA significantly increased LDH release ( $135 \%$ vs control), while pretreatment with compounds 1, 84, 97, and 102 protected against this increased $\mathrm{LDH}$ release $(76 \%, 87 \%, 82 \%$, $82 \%$ vs $6-$ OHDA, respectively), thus indicating improved cell viability. In the confirmation using flow cytometry, the proportion of PI-positive cells increased after the active $24 \mathrm{~h}$ treatment with 6-OHDA and was significantly reduced following the pretreatments with the hMAO-B inhibitors 84 and 97 ( 0.65 and 0.68 , respectively), compared to the 6OHDA-treated cells. Altogether, this indicates that the selective hMAO-B inhibitors 84 and 97 reduced the 6OHDA-induced cytotoxicity and increased the viability of these SH-SY5Y neuronal-like cells.

In Vivo MAO Inhibition in Mouse Brain Homogenates and in Vitro Permeability. The inhibition of the MAOs in mouse brain homogenates was also investigated both in vitro and ex vivo (Table 3 ). Here, the more potent of the inhibitors 
Table 3. In Vitro and ex Vivo Mouse Brain Homogenate Residual Activities of 69 and 100 at $60 \mathrm{mg} / \mathrm{kg}$ ip on MAO-A and MAO-B According to Substrate ${ }^{a}$

\begin{tabular}{|c|c|c|c|c|c|c|}
\hline \multirow[b]{4}{*}{ compd } & \multicolumn{6}{|c|}{ residual activity (\%) } \\
\hline & \multirow{2}{*}{\multicolumn{2}{|c|}{$\begin{array}{l}\text { MAO-A substrate } \\
\text { 5-HT }(0.25 \mathrm{mM})\end{array}$}} & \multirow{2}{*}{\multicolumn{2}{|c|}{$\begin{array}{c}\text { MAO-A/B substrate } \\
p \text {-tyramine }(0.5 \mathrm{mM})\end{array}$}} & \multirow{2}{*}{\multicolumn{2}{|c|}{$\begin{array}{c}\text { MAO-B substrate } \\
\text { benzylamine }(0.5 \mathrm{mM})\end{array}$}} \\
\hline & & & & & & \\
\hline & in vitro ${ }^{b}$ & ex vivo ${ }^{c}$ & in vitro ${ }^{b}$ & ex vivo ${ }^{c}$ & in vitro ${ }^{b}$ & ex vivo ${ }^{c}$ \\
\hline 69 & $-1.3 \pm 0.1$ & $1.6 \pm 0.02$ & $31.3 \pm 0.2$ & $14.2 \pm 0.2$ & nd & nd \\
\hline 100 & nd & nd & $59.4 \pm 0.2$ & $77.2 \pm 0.2$ & $-7.7 \pm 0.2$ & $24.3 \pm 0.5$ \\
\hline
\end{tabular}

${ }^{a}$ Data are mean values \pm SD $\left(n=1\right.$, in triplicate). nd, not determined. ${ }^{b}$ In vitro: $50 \mu \mathrm{M}$ compounds (final concentrations) versus $0.9 \%$ saline with mouse brain homogenate from nontreated mice. ${ }^{c} E x$ vivo: brain homogenates from mice treated ( $n=3$, per group) with $60 \mathrm{mg} / \mathrm{kg}$ ip compounds or $0.9 \%$ saline $30 \mathrm{~min}$ before brain homogenate preparation.
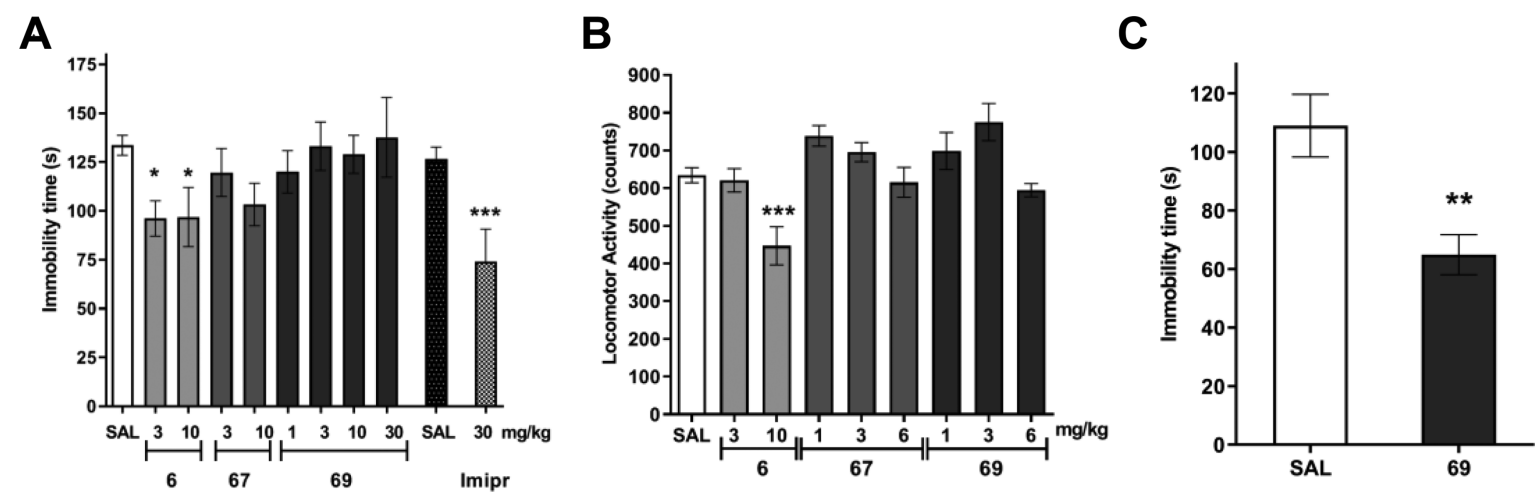

Figure 9. In vivo evaluation in mice of antidepressant-like activity of the selective MAO-A inhibitors 6, 67, and 69. (A) Effects of acute ip treatment with $6(3,10 \mathrm{mg} / \mathrm{kg}, n=13,9), 67(3,10 \mathrm{mg} / \mathrm{kg}, n=6,10)$, and $69(1,3,10,30 \mathrm{mg} / \mathrm{kg}, n=8,7,8,6)$ and imipramine $(30 \mathrm{mg} / \mathrm{kg}, n=8)$ in the tail suspension test. Data are mean values \pm SEM of immobility time in comparison to control mice (SAL, $n=23$ ): $*, p<0.05 ; * * *, p<0.001$ (one-way ANOVA, followed by Dunnett's tests). (B) Effects of acute ip treatment with $6(3,10 \mathrm{mg} / \mathrm{kg}, n=8,8), 67(1,3,6 \mathrm{mg} / \mathrm{kg} ; n=5,5,5)$, and $69(1,3,6 \mathrm{mg} / \mathrm{kg}, n=10,5,5)$ on locomotor activity of the mice. Data are mean values \pm SEM of spontaneous locomotor activity counts recorded in 5 min sessions: $* * *, p<0.001$ (one-way ANOVA, followed by Dunnett's tests). (C) Effects of 10-day chronic ip treatment with 69 $(0.3 \mathrm{mg} / \mathrm{kg}$, daily; $n=10)$ in the tail suspension test. Data are mean values \pm SEM of the immobility time, compared to control mice $(n=8): * *, p$ $<0.01$ (unpaired $t$-test).

against hMAO-A (i.e., 69) and hMAO-B (i.e., 100) were tested based on their $\mathrm{IC}_{50}$ values and structural features. Brain homogenates from male Swiss mice were first characterized in terms of their MAOs activity and substrate specificity (Table S2, Figure S6).

Compound 69 completely abolished MAO-A activity in vitro at $50 \mu \mathrm{M}$ when 5 -HT was used as the selective MAO-A substrate. Compound $\mathbf{1 0 0}$ at $50 \mu \mathrm{M}$ inhibited mice MAO-B when benzylamine was used as the selective MAO-B substrate (Table 3). When the dual hMAO-A/B substrate $p$-tyramine was used, the inhibition was lower (i.e., higher residual activities; RAs). The same profile of inhibition was established ex vivo for brain homogenates from mice treated with these compounds, which were injected intraperitoneally (ip) $30 \mathrm{~min}$ before preparation of the brain homogenates. Again, more potent inhibition was seen in these brain homogenates when the isoenzyme-selective substrates were used. Selective MAOA inhibitor 69 was the most active compound when administered at $60 \mathrm{mg} / \mathrm{kg}$ ip (RA, $1.6 \% \pm 0.02 \%$ ), while 60 $\mathrm{mg} / \mathrm{kg}$ ip 100 resulted in similar MAO-B inhibition (RA, $24.3 \% \pm 0.5 \%)$. Compounds 69 and 100 showed dosedependent inhibition of these corresponding MAO isoforms $\left(\mathrm{ED}_{50}\right.$ of $0.43 \pm 0.26 \mathrm{mg} / \mathrm{kg}$ and $1.38 \pm 0.87 \mathrm{mg} / \mathrm{kg}$, respectively).

MAO inhibitors are in clinical use for treatment of psychiatric and neurological disorders, where they are used in chronic, low-dose regimes. ${ }^{29}$ These MAO-A and MAO-B activities in ex vivo mouse brain homogenates were therefore studied after chronic 10-day administration to the mice of 69 and 100 at the low dose of $0.3 \mathrm{mg} / \mathrm{kg}$ ip. This chronic administration of selective MAO-A inhibitor 69 significantly reduced MAO-A activity compared to $0.9 \%$ saline ip in the control mice. After the single administration of 69 at $0.3 \mathrm{mg} /$ $\mathrm{kg}$ ip, the ex vivo MAO-A RA was reduced to $67.8 \% \pm 31.2 \%$ (i.e., compared to $0.9 \%$ saline), whereas the 10 -day treatment resulted in MAO-A RA of $9.5 \% \pm 23.4 \%$. Similar to 69 , one single ip injection of 100 at $0.3 \mathrm{mg} / \mathrm{kg}$ showed MAO-B RA of $83.4 \% \pm 19.2 \%$, while chronic 10 -day treatment resulted in RA of $28.3 \% \pm 13.8 \%$, which demonstrated accumulation of inhibition over time.

The ex vivo inhibitory activity of inhibitors 69 and 100 was also demonstrated in the mouse brain homogenates prepared 90 min after acute oral administration to the mice, via oral gavage at $30 \mathrm{mg} / \mathrm{kg}$. Inhibitors 69 and 100 showed RAs of $45.3 \% \pm 14.6 \%$ (vs $0.9 \%$ saline-treated mice) and $30.5 \% \pm$ $10.4 \%$ (vs $0.9 \%$ saline treated mice), respectively. This prompted us to also study gut permeability of these representative inhibitors (i.e., 69, 84, and 100) in vitro on rat intestine. The apparent bidirectional permeability coefficient for the rat intestine in vitro was determined for 69. This was $108 \pm 13 \mathrm{~nm} / \mathrm{s}$ (as mean \pm SEM) in the absorptive direction and $354 \pm 99 \mathrm{~nm} / \mathrm{s}$ in the eliminatory direction. For comparison, the apparent permeability coefficients of the internal low- and high-permeability standards furosemide and metoprolol in the absorptive direction were $64 \pm 11 \mathrm{~nm} / \mathrm{s}$ and $140 \pm 18 \mathrm{~nm} / \mathrm{s}$, respectively. 
Behavioral Studies with the Selective MAO-A and MAO-B Inhibitors. MAO-A inhibitors are currently used in the therapy of treatment-resistant major depressive disorder and some specific types of depression. ${ }^{30}$ Symptoms of depression correlate highly with those of anxiety. ${ }^{31}$ These have been shown to be associated with $5-\mathrm{HT}_{1 \mathrm{~A}}$ receptors, ${ }^{32}$ which are presynaptic and postsynaptic G-protein-coupled receptors that are involved in neuromodulation. $5-\mathrm{HT}_{1 \mathrm{~A}}$ receptor agonists, such as buspirone, show efficacy for the relief of anxiety and depression. ${ }^{32}$ The binding affinities $\left(K_{\mathrm{i}}\right.$ values) for this $5-\mathrm{HT}_{1 \mathrm{~A}}$ receptor subtype were thus determined for these MAO inhibitors to potentially further explain their behavioral effects. These ranged from low micromolar to submicromolar $K_{\mathrm{i}}$ values (Table S3). Following treatments with the selective irreversible MAO-A inhibitors 6, 67, and 69, the Swiss mice were subjected to the different behavioral tasks to determine whether these compounds have any antidepressant-like activity, any activity in an anxiety model and whether they affect locomotor activity. ${ }^{33}$

The antidepressant-like activity was screened with the widely used tail suspension test. At $30 \mathrm{~min}$ before the behavioral assays, the mice were treated with 6,67 , and 69 at $3 \mathrm{mg} / \mathrm{kg}$ and $10 \mathrm{mg} / \mathrm{kg}$ ip, with 69 also at $1 \mathrm{mg} / \mathrm{kg}$ and $30 \mathrm{mg} / \mathrm{kg}$ ip, or were injected with $0.9 \%$ saline as control. Imipramine $(30 \mathrm{mg} /$ $\mathrm{kg}$ ip) was used as the reference drug. Compounds 67 and 69 did not decrease the immobility time, whereas selective MAOA inhibitor 6 and imipramine significantly reduced it, which demonstrated the antidepressant-like effects of these compounds under acute treatment (Figure 9A).

The performance of mice in the "elevated plus maze test" was used here as a rodent model of anxiety, which was carried out 30 min after the ip treatments with 6, 67, and 69 (Table S4). Compound 6 at the dose of $10 \mathrm{mg} / \mathrm{kg}$ ip induced a significant decrease compared to mice injected with $0.9 \%$ saline, for both the number of total arm entries $(9.7 \pm 2.9$ vs $22.0 \pm 1.5 ; p<0.001)$ and the proportion of time spent in the center of the apparatus $(13.4 \pm 2.3$ vs $43.5 \pm 2.8$; $p<0.001)$, and also an increase in the proportion of open-arm entries (2.0-fold; $p<0.001)$. Meanwhile, 69 at $3 \mathrm{mg} / \mathrm{kg}$ ip produced a significant increase in the proportion of open-arm entries (2.0fold; $p<0.001)$ and in the time spent in those entries $(2.1$ fold; $p<0.001$ ), similar to diazepam (reference drug) at $1 \mathrm{mg} /$ $\mathrm{kg}$ ip (2.1-fold, 2.4-fold, respectively; $p<0.001$ for both).

The locomotor activity of the mice was also determined, as it can affect the data obtained in these behavioral assays. It was shown that 6 at $10 \mathrm{mg} / \mathrm{kg}$ ip significantly decreased spontaneous locomotor activity (Figure 9B), which is correlated with the decrease in the total arm entries in the elevated plus maze test. This indicates that the effects of $\mathbf{6}$ after acute $10 \mathrm{mg} / \mathrm{kg}$ ip treatment are not associated with antidepressant-like or anxiolytic effects but rather with a decrease in the locomotion of the mice. On the other hand, the increased open arm parameters in the elevated plus maze for $69(3 \mathrm{mg} / \mathrm{kg}$ ip) appear to be correlated with an anxiolytic-like effect, which would be mediated through the $5-\mathrm{HT}_{1 \mathrm{~A}}$ receptor, as locomotion was not altered at this dose of 69. Importantly, chronic 10-day treatment with 69 at a low dose (i.e., $0.3 \mathrm{mg} / \mathrm{kg}$ ip, daily) significantly decreased the immobility time in the treated group (Figure 9C). No significant effects were seen for this chronic low dose of 69 in the elevated plus maze and locomotor activity tests (Table S5). This confirmed the antidepressant-like effects of $\mathbf{6 9}$ when administered chronically, which were not seen for the acute treatment regime.
Behavioral studies of the selective hMAO-B inhibitors were performed with compound 100 (irreversible MAO-B inhibitor). Although trans derivative 84 also showed potent irreversible MAO-B inhibition $\left(\mathrm{IC}_{50}=18.6 \pm 3.3 \mathrm{nM}\right.$; equipotent to 100), it was not studied here in vivo due to its poor permeability in the rat gut (see above) and its low binding potential for the $5-\mathrm{HT}_{1 \mathrm{~A}}$ receptor (Table $\mathrm{S} 3$ ).

The hole-board test is commonly used to study stressrelated changes in exploratory behavior of animals. ${ }^{34}$ This was combined here with the locomotor activity test. At acute ip doses of $\geq 10 \mathrm{mg} / \mathrm{kg}$ of $\mathbf{1 0 0}$ in the mice, the hole-board test parameters and locomotor activities were reduced (Table S6, Figure S7A-C). Due to the locomotor impairment at high doses, compound $\mathbf{1 0 0}$ was further studied in the haloperidolinduced catalepsy test at lower doses (see Supplementary Results and Discussion). Compound $\mathbf{1 0 0}$ was also tested in the same battery of behavioral tests after 10 days of low-dose ip treatment $(0.3 \mathrm{mg} / \mathrm{kg}$, daily), where it did not affect the locomotor activity of the mice (Figure S7D) or the parameters of the hole-board test (Figure S8). During these 10-day treatments (i.e., 69,100 at $0.3 \mathrm{mg} / \mathrm{kg}$ ip, daily), the body mass of the mice was also monitored (Figure S9). No significant differences were seen for the proportions of body mass variations versus the control mice $(0.9 \%$ saline treated $)$. Also, all of these mice survived these 10-day treatments without any apparent signs of changes in behavior, which supports the general safety of these compounds.

\section{DISCUSSION AND CONCLUSIONS}

Biological receptors differ greatly in shape, polarity, and conformational dynamics. ${ }^{1}$ However, it is a challenging task to obtain selectivity between structurally related targets such as isoenzymes, which requires different ligand-design approaches. $\mathrm{MAO}-\mathrm{A}$ and MAO-B are two closely related isoenzymes where numerous selective inhibitors have been described in the literature, with some now used in the clinical setting for treatment of neurological disorders. ${ }^{35}$

Selective hMAO-B inhibitor $\mathbf{6}$ was identified in a screening campaign, and chemistry-driven exploration of the chemical space revealed that the trans isomers selectively inhibit hMAO$\mathrm{B}$ over hMAO-A. On the other hand, cis isomers were identified as selective hMAO-A inhibitors. The inhibitory potencies in the SARs exploration phase are generally expressed as $\mathrm{IC}_{50}$ values (Table 1), although these derivatives are irreversible. The $\mathrm{IC}_{50}$ values are thus dependent on the assay conditions and particularly on the preincubation period. ${ }^{36}$ Despite these limitations, the measured $\mathrm{IC}_{50}$ values still allow relatively simple, yet not the most precise, comparisons between such compounds in a series. ${ }^{11}$ The inhibitory activity against hMAO-B was increased by introducing bulkier and more lipophilic substituents onto position 4 of the phenyl ring, as previously reported in the literature. ${ }^{37} \mathrm{~A}$ similar trend was also observed for the turnover of variously substituted substrates of the benzylamine and phenethylamine classes, ${ }^{38}$ where the binding affinity improved with increasing hydrophobicity of the substituent.

Further examination of the binding kinetics for the selected compounds here using purified enzyme samples confirmed the variable nature of these $\mathrm{IC}_{50}$ values. The overall higher affinity inferred from the $\mathrm{IC}_{50}$ values (Table 1 ) compared to $K_{\mathrm{i}}$ (Table 2 ) is related to the covalent nature of these inhibitors, which fully inactivate the enzyme during the preincubation step in the absence of substrate (not included in competitive steady-state 
experiments used to determine $\left.\mathrm{IC}_{50}\right)$. For the same reason, the variability of the $\mathrm{IC}_{50}$ values among the different inhibitors that was not seen for $K_{\mathrm{i}}$ has to be interpreted in light of the timedependent inactivation process that showed different kinetics depending on the inhibitor (Table 2). For example, 84 showed an $\mathrm{IC}_{50}$ that is 0.05 -fold that of $\mathbf{1}$ and a similar reversible $K_{\mathrm{i}}$, while its inactivation rate was 4 -fold that of 1 , which results in a $k_{\text {inact }} / K_{\mathrm{I}}$ ratio that is comparable between these two inhibitors. Similar observations can be reasoned for the other covalent analogues and for L-deprenyl.

Crystallographic studies confirmed the covalent adduct formation with flavin for the inhibitors investigated here. A similar binding mode for all of these inhibitors was seen, with only minor modifications of the active site arrangements in comparison to other hMAO-B structures reported in the literature. These changes were most prominent with the trans inhibitors 1 and 84, which imposed a slight upward shift of Cys 172 and Tyr188. This is related to the conformation adopted by the piperidine ring, which represents the hallmark of this class of inhibitors, as a novel element with respect to previous propargyl inhibitors (i.e., where the nitrogen atom is within a linear molecular structure rather than part of a ring).

The inhibitor series studied here were not cytotoxic to $\mathrm{SH}$ SY5Y cells up to treatments of $50 \mu \mathrm{M}$. Remarkably, only the selective hMAO-B inhibitors decreased the $\mathrm{LDH}$ release induced by the neurotoxin 6-OHDA. The reduced proportion of PI-positive SH-SY5Y cells was also confirmed for the two MAO-B-selective ligands during 6-OHDA-induced toxicity. This indicated their neuroprotective nature, which might also be attributed, among others possibilities, to their selective MAO-B inhibition. Following ip and peroral administration, these compounds inhibited MAO-A and MAO-B activities ex vivo in the mouse brain homogenates. The extent of their inhibition varied depending on the inhibitor selectivity and the substrate used. Selective MAO-A inhibitor 69 completely inhibited MAO-A ex vivo when the MAO-A substrate 5-HT was used (RA, 1.6\%), while its inhibition was lower when using p-tyramine (RA, 14.2\%), which is a dual MAO-A/B substrate. The difference is even more evident for the MAO-B inhibitors, with decreased inhibition when switching from the MAO-B substrate benzylamine to dual substrate $p$-tyramine. Both MAO-A and MAO-B can metabolize $p$-tyramine; however, only one of them was inhibited by the selective inhibitor, which explained the impaired inhibition. This additionally confirmed the in vitro selectivity of these inhibitors not only on the isolated human enzymes but also in complex matrices, such as mouse brain homogenates. The MAO inhibition in these mouse brain homogenates after peroral single-dose administration also indicated the oral bioavailability of these analogues. The in vitro permeability of 69 studied for rat intestine was between that of the low-permeability and highpermeability standards, and as such, 69 should be classified with an intermediate/moderate permeability, with the possibility of interference by the intestinal efflux mechanisms, as seen by the higher apparent permeability coefficient determined for the eliminatory direction. The permeabilities of $\mathbf{8 4}$ and $\mathbf{1 0 0}$ were not determinable in vitro due to their high tissue binding. These findings do not correlate directly with the ex vivo effects; however, the ex vivo effects show that both 69 and $\mathbf{1 0 0}$ reached the brain tissue and inhibited the MAO activity after their oral administration.

Under the acute treatment regime in these mice, the selective MAO-A inhibitor 69 did not affect the immobility time of the mice in the tail suspension test. The observed anxiolytic-like activity with acute treatment with 69 , which can be attributed to 5- $\mathrm{HT}_{1 \mathrm{~A}}$ binding, prompted us to also study 69 in a 10-day treatment regime. The antidepressant-like effects of 69 in this setup, together with no significant toxic effects, confirmed the therapeutic potential for this class of selective hMAO-A inhibitors. On the other hand, the selective MAO-B inhibitor 100 did not produce the expected results for haloperidol-induced catalepsy, in terms of what would be expected for a MAO-B inhibitor. ${ }^{39}$ Nonetheless, the general safety of these compounds has been established in the chronic low-dose treatment regime.

In summary, we have generated the first example of selective hMAO-A and hMAO-B inhibitors where this selectivity is conferred by the configurational cis/trans isomerism of a double bond. Cis isomers with fluorine or unsubstituted benzene ring selectively inhibit hMAO-A. On the other hand, trans derivatives and their corresponding reduced ethyl analogues with small lipophilic substituents on benzene ring selectively inhibit hMAO-B. In addition, we provide the first in depth, and we believe critical, kinetic and structural characterization of these 1-propargyl-4-styrylpiperidines as potential fragments in the design of pharmaceuticals that can be used to target the MAOs.

\section{EXPERIMENTAL SECTION}

Chemistry. General Information. The reagents and solvents used were obtained from commercial sources (i.e., Acros Organics, Sigma-Aldrich, TCI Europe, Merck, Carlo Erba, Apollo Scientific) and were used as provided. Anhydrous THF was prepared by distillation over sodium and benzophenone under $\operatorname{Ar}(\mathrm{g})$. Analytical thin-layer chromatography was performed on silica gel aluminum sheets (60 F254, $0.20 \mathrm{~mm}$; Merck). Flash column chromatography was performed on silica gel 60 (particle size $0.040-0.063 \mathrm{~mm}$, Merck). ${ }^{1} \mathrm{H}$ NMR and ${ }^{13} \mathrm{C}$ spectra were recorded at 400 and 100 $\mathrm{MHz}$, respectively, on a Bruker Avance III NMR spectrometer (Bruker, MA, USA) at $295 \mathrm{~K}$. The chemical shifts $(\delta)$ are reported in $\mathrm{ppm}$ and are referenced to the deuterated solvent used. HRMS measurements were performed (Autospec Q Micromass MS; Fisons, VG Analytical, Manchester, U.K.) at the Jozef Stefan Institute, Ljubljana, Slovenia, and on a LC-MS/MS system (Q Executive Plus; Thermo Scientific, MA, USA). MS measurements were performed on an Expression CMS mass spectrometer (Advion, NY, USA). Infrared spectra were obtained on a Thermo Nicolet FT-IR spectrometer using the ATR technique. Analytical reversed-phase HPLC analyses were performed on a modular system (1100LC; Agilent Technologies, CA, USA, and Thermo Scientific Dionex UltiMate 3000; Thermo Fisher Scientific Inc., MA, USA). Method: C18 column (Eclipse Plus; $5 \mu \mathrm{m}$, $4.6 \mathrm{~mm} \times 150 \mathrm{~mm}$; Agilent), $T=25{ }^{\circ} \mathrm{C}$; sample $0.2 \mathrm{mg} / \mathrm{mL}$ in $\mathrm{MeCN}$; flow rate $=1.0 \mathrm{~mL} / \mathrm{min}$; detector $\lambda=220 \mathrm{~nm}$; mobile phase A (0.1\% TFA $[v / v]$ in water), mobile phase B $(\mathrm{MeCN})$. Gradient (for mobile phase B): $0-12 \mathrm{~min}, 10-90 \%$; $12-14 \mathrm{~min}, 90 \%$; $14-15 \mathrm{~min}$, $90-10 \%$. Purities of the tested compounds were established to be $\geq 95 \%$, as determined by HPLC. All compounds described in Table 1 were checked by SwissADME ${ }^{40}$ for the presence of PAINS substructures, ${ }^{41}$ and no PAINS substructures were identified.

General Synthetic Chemistry Experimental Protocols. General Procedure A: Synthesis of Wittig Reagents. Appropriate benzyl halide ( $25.0 \mathrm{mmol}, 1.0$ equiv) was dissolved in $\mathrm{MeCN}$ $(25-50 \mathrm{~mL})$, and triphenylphosphine $(6.56 \mathrm{~g}, 25.0 \mathrm{mmol}, 1.0$ equiv) was added at room temperature. The reaction mixture was stirred at $85^{\circ} \mathrm{C}$ for $16-24 \mathrm{~h}$. The solvent was evaporated, and $\mathrm{CH}_{2} \mathrm{Cl}_{2}(10 \mathrm{~mL})$ and $\mathrm{Et}_{2} \mathrm{O}(50 \mathrm{~mL})$ were added to the residue. The precipitated solid was filtered off, washed with $\mathrm{Et}_{2} \mathrm{O}(20 \mathrm{~mL})$, and dried overnight at room temperature. The crude product was used in the following reaction step without further purification. 
General Procedure B: Wittig Reaction. Appropriate Witting reagent synthesized according to general procedure $A$ (1.1 equiv) was dissolved in anhydrous THF $(30 \mathrm{~mL})$ under argon atmosphere. NaHMDS ( $2 \mathrm{~N}$ in THF, 1.2 equiv) or KHMDS (0.5 M in toluene, 1.1 equiv) was added to the resulting suspension at room temperature. The orange-red colored reaction mixture was then stirred for $30 \mathrm{~min}$ under argon, followed by a dropwise addition of $\mathrm{N}$ Boc protected 3- or 4- formylpiperidine (1.0 equiv) solution in anhydrous THF $(10 \mathrm{~mL})$. The reaction mixture was stirred at room temperature overnight $(16-24 \mathrm{~h})$ and then quenched by adding saturated aqueous $\mathrm{NaHCO}_{3}$ solution $(10-15 \mathrm{~mL})$. The solvent was evaporated, and the white residue was resuspended in EtOAc (50 $\mathrm{mL}$ ) and saturated aqueous $\mathrm{NaHCO}_{3}$ solution $(50 \mathrm{~mL})$ and transferred into a separating funnel. The phases were separated, and the aqueous phase was additionally extracted with EtOAc $(2 \times 50$ $\mathrm{mL})$. Combined organic phases were washed with saturated brine $(100 \mathrm{~mL})$, dried over $\mathrm{Na}_{2} \mathrm{SO}_{4}$, and evaporated. The crude product was purified by flash column chromatography to yield (in a majority of cases) both pure cis and trans isomers.

General Procedure C: Reduction of the Double Bond. Alkene derivative (Wittig reaction product-mixture of $c$ is and trans isomer, 1.0 equiv) was dissolved in EtOH $(50 \mathrm{~mL})$ and purged under a stream of argon for $10 \mathrm{~min}$. Catalytic amount of Pd/C (10\% load on carbon, $10-20 \%[\mathrm{w} / \mathrm{w}]$ calculated to the starting material) was added, and the resulting suspension mixture was stirred under $\mathrm{H}_{2}(\mathrm{~g})$ atmosphere at room temperature for 16-24 h. The catalyst was removed by filtration through Celite and evaporated to obtain crude product. The product was used without further purification unless stated otherwise.

General Procedure D: Boc Protection Removal $(\mathrm{HCl}$ Method). To the solution of Boc-protected derivative (1.0 equiv) in 1,4-dioxane or $\mathrm{EtOH}(30 \mathrm{~mL})$, concentrated $\mathrm{HCl}$ (10.0 equiv) was added at room temperature. The reaction mixture was stirred at $80{ }^{\circ} \mathrm{C}$ for $2 \mathrm{~h}$. The solvent was evaporated under reduced pressure, and the crude product was used in the next step without further purification.

General Procedure E: Alkylation of Piperidine. Piperidine intermediate (in the form of the salt with $\mathrm{HCl}$ ) was dissolved in $\mathrm{MeCN}(20-30 \mathrm{~mL})$ or DMF $(5-10 \mathrm{~mL})$ at $0{ }^{\circ} \mathrm{C}$ under an argon atmosphere. $\mathrm{K}_{2} \mathrm{CO}_{3}$ or $\mathrm{Cs}_{2} \mathrm{CO}_{3}$ (3.0 equiv) was added, followed by dropwise addition of propargyl bromide ( $80 \%$ solution in toluene, 1.2 equiv). The resulting suspension was stirred at room temperature (unless specified otherwise) for 16-72 h. The solvent was evaporated, the residue dissolved in a mixture of $\mathrm{CH}_{2} \mathrm{Cl}_{2}(50 \mathrm{~mL})$ and saturated aqueous $\mathrm{NaHCO}_{3}$ solution $(50 \mathrm{~mL})$ and transferred into a separating funnel. The organic phase was further washed with saturated brine solution $(50 \mathrm{~mL})$, dried over $\mathrm{Na}_{2} \mathrm{SO}_{4}$, and evaporated. The crude product was purified by flash column chromatography.

General Procedure F: Hydrolysis of Nitrile. The starting nitrile (1.0 equiv) was dissolved in tert-butanol $(20-50 \mathrm{~mL})$, followed by the addition of powdered $\mathrm{KOH}$ ( 3.0 equiv). The resulting suspension was stirred at $90{ }^{\circ} \mathrm{C}$ for $12-24 \mathrm{~h}$, and then the solvent was evaporated. The residue was dissolved in a mixture of $\mathrm{CH}_{2} \mathrm{Cl}_{2}(50$ $\mathrm{mL}$ ) and saturated aqueous $\mathrm{NaHCO}_{3}(50 \mathrm{~mL})$ and transferred into a separating funnel. The water layer was additionally extracted with $\mathrm{CH}_{2} \mathrm{Cl}_{2}(50 \mathrm{~mL})$. The combined organic layers were washed with saturated brine $(50 \mathrm{~mL})$, dried over $\mathrm{Na}_{2} \mathrm{SO}_{4}$, and evaporated. The crude product was purified by flash column chromatography.

Synthesis of Intermediates and Inhibitors. (E)-4-(4-Fluorostyryl)-1-(prop-2-yn-1-yl)piperidine (1). Synthesized from 5 $(0.157 \mathrm{~g}, 0.514 \mathrm{mmol}, 1.0$ equiv) via general procedures $\mathrm{D}$ and $\mathrm{E}$. Column chromatography, EtOAc/n-hex $=1 / 1(\mathrm{v} / \mathrm{v})$. Yield: $26 \%(33$ $\mathrm{mg}$ ); yellow oil. ${ }^{1} \mathrm{H}$ NMR $\left(400 \mathrm{MHz}, \mathrm{CDCl}_{3}\right): \delta 1.57(\mathrm{dt}, J=12.3$, $3.4 \mathrm{~Hz}, 1 \mathrm{H}), 1.60(\mathrm{dt}, J=12.0,3.7 \mathrm{~Hz}, 1 \mathrm{H}), 1.77-1.83(\mathrm{~m}, 2 \mathrm{H})$, $2.08-2.18(\mathrm{~m}, 1 \mathrm{H}), 2.27(\mathrm{t}, J=2.4 \mathrm{~Hz}, 1 \mathrm{H}), 2.30(\mathrm{dd}, J=11.7,2.0$ $\mathrm{Hz}, 2 \mathrm{H}), 2.95(\mathrm{td}, J=11.1,2.8 \mathrm{~Hz}, 2 \mathrm{H}), 3.34(\mathrm{~d}, J=2.4 \mathrm{~Hz}, 2 \mathrm{H})$, 6.07 (dd, $J=16.0,7.0 \mathrm{~Hz}, 1 \mathrm{H}), 6.34(\mathrm{~d}, J=16.0 \mathrm{~Hz}, 1 \mathrm{H}), 6.95-7.00$ $(\mathrm{m}, 2 \mathrm{H}), 7.28-7.33(\mathrm{~m}, 2 \mathrm{H}) .{ }^{13} \mathrm{C} \mathrm{NMR}\left(100 \mathrm{MHz} \mathrm{CDCl}_{3}\right): \delta 31.89$, $38.71,47.20,52.19,73.26,78.73,115.31\left(\mathrm{~d}, J_{\mathrm{C}, \mathrm{F}}=21.4 \mathrm{~Hz}\right), 127.14$, $127.41\left(\mathrm{~d}, J_{\mathrm{C}, \mathrm{F}}=7.7 \mathrm{~Hz}\right), 133.70\left(\mathrm{~d}, J_{\mathrm{C}, \mathrm{F}}=3.3 \mathrm{~Hz}\right), 134.49,161.94(\mathrm{~d}$, $J_{\mathrm{C}, \mathrm{F}}=245.9 \mathrm{~Hz}$ ). HRMS (ESI +$): m / z$ calcd for $\mathrm{C}_{16} \mathrm{H}_{19} \mathrm{FN}[\mathrm{M}+\mathrm{H}]^{+}$ 244.1502; found 244.1508. IR (ATR): 3287, 2925, 2804, 1599, 1507,
$1425,1314,1222,1124,966,855,669,631 \mathrm{~cm}^{-1}$. HPLC purity, $96.2 \%\left(t_{\mathrm{R}}=9.11 \mathrm{~min}\right)$.

tert-Butyl 4-(Methoxy(methyl)carbamoyl)piperidine-1-carboxylate (2). Piperidine-4-carboxylic acid (15.00 g, $116.1 \mathrm{mmol}$, 1.0 equiv) was dissolved in a mixture of 1,4 -dioxane $(75 \mathrm{~mL})$ and $1 \mathrm{M}$ $\mathrm{NaOH}\left(116.1 \mathrm{~mL}, 116.1 \mathrm{mmol}, 1.0\right.$ equiv) and cooled to $0{ }^{\circ} \mathrm{C}$. A solution of $\mathrm{Boc}_{2} \mathrm{O}$ (30.41 g, $139.3 \mathrm{mmol}, 1.2$ equiv) in 1,4-dioxane $(100 \mathrm{~mL})$ was added dropwise over $30 \mathrm{~min}$. The resulting suspension was stirred at room temperature for $1 \mathrm{~h}$. The organic solvent was evaporated, and the aqueous residue was transferred into a separating funnel and extracted with $\mathrm{Et}_{2} \mathrm{O}(2 \times 100 \mathrm{~mL})$. The aqueous layer was acidified with $2 \mathrm{M} \mathrm{HCl}$ to $\mathrm{pH} 2-3$. The precipitated solid was filtered under suction, washed with cold water $(100 \mathrm{~mL})$, and dried at $50{ }^{\circ} \mathrm{C}$ overnight to obtain 1-(tert-butoxycarbonyl)piperidine-4-carboxylic acid. Yield: $91 \%(24.22 \mathrm{~g})$; white crystals, mp $158-160{ }^{\circ} \mathrm{C} .{ }^{1} \mathrm{H}$ $\operatorname{NMR}\left(400 \mathrm{MHz}, \mathrm{CDCl}_{3}\right): \delta 1.46(\mathrm{~s}, 9 \mathrm{H}), 1.62-1.69(\mathrm{~m}, 2 \mathrm{H}), 1.88-$ $1.94(\mathrm{~m}, 2 \mathrm{H}), 2.48(\mathrm{tt}, J=10.9,3.9 \mathrm{~Hz}, 1 \mathrm{H}), 2.82-2.89(\mathrm{~m}, 2 \mathrm{H})$, $4.03(\mathrm{td}, J=13.6,3.7 \mathrm{~Hz}, 2 \mathrm{H}), 9.13$ (bs, $1 \mathrm{H})$.

1-(tert-Butoxycarbonyl)piperidine-4-carboxylic acid (10.00 g, 43.61 mmol, 1.0 equiv) was suspended in $\mathrm{CH}_{2} \mathrm{Cl}_{2}(150 \mathrm{~mL})$ and cooled to $0{ }^{\circ} \mathrm{C}$. Then $\mathrm{Et}_{3} \mathrm{~N}$ (15.11 mL, $109.03 \mathrm{mmol}, 2.5$ equiv) was added, followed by TBTU ( $14.70 \mathrm{~g}, 45.78 \mathrm{mmol}, 1.05$ equiv). After stirring for $30 \mathrm{~min}$ at $0{ }^{\circ} \mathrm{C}, \mathrm{N}, \mathrm{O}$-dimethylhydroxylamine hydrochloride $(5.10$ g, $52.32 \mathrm{mmol}, 1.2$ equiv) was added, and the mixture was stirred overnight at room temperature. The resulting solution was transferred into a separating funnel and washed with saturated aqueous $\mathrm{NaHCO}_{3}$ solution $(2 \times 100 \mathrm{~mL}), 1 \mathrm{M} \mathrm{HCl}(100 \mathrm{~mL})$, saturated brine solution $(100 \mathrm{~mL})$, dried over $\mathrm{Na}_{2} \mathrm{SO}_{4}$, and evaporated. Column chromatography, EtOAc/n-hex = 1/2 (v/v). Yield: $76 \%(9.03 \mathrm{~g})$; white crystals, mp $68-72{ }^{\circ} \mathrm{C} .{ }^{1} \mathrm{H}$ NMR $\left(400 \mathrm{MHz}, \mathrm{CDCl}_{3}\right): \delta 1.45$ (s, 9H), 1.61$1.74(\mathrm{~m}, 4 \mathrm{H}), 2.72-2.83(\mathrm{~m}, 3 \mathrm{H}), 3.17(\mathrm{~s}, 3 \mathrm{H}), 3.70(\mathrm{~s}, 3 \mathrm{H}), 4.17$ (td, $J=13.4,2.9 \mathrm{~Hz}, 2 \mathrm{H})$.

tert-Butyl 4-Formylpiperidine-1-carboxylate (3). tert-Butyl 4(methoxy(methyl)carbamoyl)piperidine-1-carboxylate 2 (9.03 g, $33.16 \mathrm{mmol}, 1.0$ equiv) was dissolved in anhydrous THF $(75 \mathrm{~mL})$ and cooled to $0{ }^{\circ} \mathrm{C}$. After stirring $10 \mathrm{~min}$ under an argon atmosphere, $\mathrm{LiAlH}_{4}(1.89 \mathrm{~g}, 49.73 \mathrm{mmol}, 1.5$ equiv) was added. The mixture was stirred at $0{ }^{\circ} \mathrm{C}$ for $2 \mathrm{~h}$ and afterward quenched by adding saturated aqueous $\mathrm{NaHCO}_{3}$ solution $(30 \mathrm{~mL})$. The suspension formed was transferred into a separating funnel and extracted with EtOAc $(3 \times$ $100 \mathrm{~mL}$ ). Combined organic phases were washed with saturated aqueous $\mathrm{NaHCO}_{3}$ solution $(100 \mathrm{~mL}), 1 \mathrm{M} \mathrm{HCl}(100 \mathrm{~mL})$, saturated brine solution $(100 \mathrm{~mL})$, dried over $\mathrm{Na}_{2} \mathrm{SO}_{4}$, and evaporated. The crude product was used without further purification. Yield: 83\% (5.87 g); pale yellow oil.

tert-Butyl 4-(4-Fluorostyryl)piperidine-1-carboxylate [Isomers $(Z)-4$ and $(E)-5$ ]. Synthesized from aldehyde 3 (2.0 g, 9.38 mmol, 1.0 equiv), (4-fluorobenzyl)triphenylphosphonium bromide (4.66 g, $10.3 \mathrm{mmol}, 1.1$ equiv) and NaHMDS ( $2 \mathrm{~N}$ in THF, $5.63 \mathrm{~mL}$, $11.26 \mathrm{mmol}, 1.2$ equiv) via general procedure $\mathrm{B}$. Column chromatography, petroleum ether $/ \mathrm{Et}_{2} \mathrm{O}=10 / 1(\mathrm{v} / \mathrm{v})$. Overall yield of reaction: $52 \%$ (mass of both $Z$ and $E$ isomers, $1.5 \mathrm{~g}$ ); isolated pure $Z$ isomer, $55 \mathrm{mg}$; isolated pure $E$ isomer, $155 \mathrm{mg}$; mixture of $E / Z$ isomers, $1.29 \mathrm{~g}$.

4: $R_{f}=0.82($ EtOAc $/ \mathrm{n}$-hex $=1 / 2, \mathrm{v} / \mathrm{v})$; white crystals, $\mathrm{mp} 80-82$ ${ }^{\circ} \mathrm{C} .{ }^{1} \mathrm{H}$ NMR $\left(400 \mathrm{MHz}, \mathrm{CDCl}_{3}\right): \delta 1.34(\mathrm{dt}, J=12.4,4.6 \mathrm{~Hz}, 1 \mathrm{H})$, $1.37(\mathrm{dt}, J=12.7,4.7 \mathrm{~Hz}, 1 \mathrm{H}), 1.45(\mathrm{~s}, 9 \mathrm{H}), 1.59-1.66(\mathrm{~m}, 2 \mathrm{H})$, $2.58-2.66(\mathrm{~m}, 1 \mathrm{H}), 2.72(\mathrm{t}, J=11.7 \mathrm{~Hz}, 2 \mathrm{H}), 4.08(\mathrm{~d}, J=12.5 \mathrm{~Hz}$, $2 \mathrm{H}), 5.44(\mathrm{dd}, J=11.6,10.1 \mathrm{~Hz}, 1 \mathrm{H}), 6.34(\mathrm{~d}, J=11.6 \mathrm{~Hz}, 1 \mathrm{H})$, 6.99-7.05 (m, 2H), 7.16-7.21 (m, 2H). HRMS (ESI+): $m / z$ calcd for $\mathrm{C}_{18} \mathrm{H}_{24} \mathrm{FNO}_{2} \mathrm{Na}[\mathrm{M}+\mathrm{Na}]^{+}$328.1689; found 328.1688.

5: $R_{f}=0.79($ EtOAc/n-hex $=1 / 2, \mathrm{v} / \mathrm{v})$; yellow oil. ${ }^{1} \mathrm{H}$ NMR $(400$ $\left.\mathrm{MHz}, \mathrm{CDCl}_{3}\right): \delta 1.30-1.42(\mathrm{~m}, 2 \mathrm{H}), 1.46(\mathrm{~s}, 9 \mathrm{H}), 1.51-1.57(\mathrm{~m}$, $1 \mathrm{H}), 1.71-1.77(\mathrm{~m}, 2 \mathrm{H}), 2.77(\mathrm{dt}, J=13.2,2.7 \mathrm{~Hz}, 2 \mathrm{H}), 4.13(\mathrm{~d}, J=$ $13.0 \mathrm{~Hz}, 2 \mathrm{H}), 6.05(\mathrm{dd}, J=15.9,6.9 \mathrm{~Hz}, 1 \mathrm{H}), 6.34(\mathrm{~d}, J=16.2 \mathrm{~Hz}$, $1 \mathrm{H}), 6.95-7.01(\mathrm{~m}, 2 \mathrm{H}), 7.27-7.32(\mathrm{~m}, 2 \mathrm{H})$. HRMS (ESI+): $\mathrm{m} / z$ calcd for $\mathrm{C}_{18} \mathrm{H}_{24} \mathrm{FNO}_{2} \mathrm{Na}[\mathrm{M}+\mathrm{Na}]^{+} 328.1689$; found 328.1686.

(Z)-4-(4-Fluorostyryl)-1-(prop-2-yn-1-yl)piperidine (6). Synthesized from $4(57 \mathrm{mg}, 0.187 \mathrm{mmol}, 1.0$ equiv) via general procedures D and E. Column chromatography, EtOAc/n-hex $=1 / 1$ 
(v/v). Yield: $72 \%$ (33 mg); white crystals, mp $45-46{ }^{\circ} \mathrm{C} .{ }^{1} \mathrm{H}$ NMR $\left(400 \mathrm{MHz}, \mathrm{CDCl}_{3}\right): \delta 1.51-1.61(\mathrm{~m}, 2 \mathrm{H}), 1.69-1.76(\mathrm{~m}, 2 \mathrm{H})$, $2.21-2.28(\mathrm{~m}, 3 \mathrm{H}), 2.45-2.55(\mathrm{~m}, 1 \mathrm{H}), 2.90(\mathrm{dt}, J=9.0,2.7 \mathrm{~Hz}$, $2 \mathrm{H}), 3.32(\mathrm{~d}, J=2.4 \mathrm{~Hz}, 2 \mathrm{H}), 5.48(\mathrm{dd}, J=11.5,10.1 \mathrm{~Hz}, 1 \mathrm{H}), 6.33$ $(\mathrm{d}, J=11.6 \mathrm{~Hz}, 1 \mathrm{H}), 6.99-7.05(\mathrm{~m}, 2 \mathrm{H}), 7.17-7.21(\mathrm{~m}, 2 \mathrm{H}) .{ }^{13} \mathrm{C}$ NMR $\left(100 \mathrm{MHz}, \mathrm{CDCl}_{3}\right): \delta 32.16,34.31,47.22,51.85,73.21,78.77$, $115.12\left(\mathrm{~d}, J_{\mathrm{C}, \mathrm{F}}=21.3 \mathrm{~Hz}\right), 127.07,130.00\left(\mathrm{~d}, J_{\mathrm{C}, \mathrm{F}}=7.9 \mathrm{~Hz}\right), 133.58$ $\left(\mathrm{d}, J_{\mathrm{C}, \mathrm{F}}=3.3 \mathrm{~Hz}\right), 137.05,161.52\left(\mathrm{~d}, J_{\mathrm{C}, \mathrm{F}}=246.1 \mathrm{~Hz}\right)$. HRMS (ESI+): $\mathrm{m} / z$ calcd for $\mathrm{C}_{16} \mathrm{H}_{19} \mathrm{FN}[\mathrm{M}+\mathrm{H}]^{+} 244.1502$; found 244.1503. IR (ATR): 3299, 2930, 1601, 1508, 1446, 1225, 1157, 972, 845, 657 $\mathrm{cm}^{-1}$. HPLC purity, $99.5 \%\left(t_{\mathrm{R}}=9.03 \mathrm{~min}\right)$.

(t)-tert-Butyl 3-(Methoxy(methyl)carbamoyl)piperidine-1carboxylate (7). Synthesis of ( \pm )-1-(tert-butoxycarbonyl)piperidine-3-carboxylic acid was carried out following the procedure described for the synthesis of compound 2, starting from ( \pm )-piperidine-3-carboxylic acid (7.75 g, $60.0 \mathrm{mmol}, 1.0$ equiv). Yield: $86 \%(11.83 \mathrm{~g})$; white crystals, $\mathrm{mp} 164-165^{\circ} \mathrm{C} .{ }^{1} \mathrm{H}$ NMR (400 $\left.\mathrm{MHz}, \mathrm{CDCl}_{3}\right): \delta 1.43-1.53(\mathrm{~m}, 1 \mathrm{H}), 1.45(\mathrm{~s}, 9 \mathrm{H}), 1.59-1.75(\mathrm{~m}$, $2 \mathrm{H}), 2.03-2.09(\mathrm{~m}, 1 \mathrm{H}), 2.48(\mathrm{tt}, J=10.2,4.0 \mathrm{~Hz}, 1 \mathrm{H}), 2.82-2.89$ (m, $1 \mathrm{H}), 3.03(\mathrm{dd}, J=12.7,10.6 \mathrm{~Hz}, 1 \mathrm{H}), 3.88(\mathrm{td}, J=13.3,4.0 \mathrm{~Hz}$, $1 \mathrm{H}), 4.08-4.15(\mathrm{~m}, 1 \mathrm{H}), 8.67$ (bs, $1 \mathrm{H})$.

( \pm )1-(Tert-butoxycarbonyl)piperidine-3-carboxylic acid (10.00 g, $43.61 \mathrm{mmol}, 1.0$ equiv) was transformed to Weinreb amide 7 following the procedure described for compound 2. Yield: $82 \%$ (9.74 $\mathrm{g}$ ); white crystals, mp $89-91{ }^{\circ} \mathrm{C} .{ }^{1} \mathrm{H}$ NMR $\left(400 \mathrm{MHz} \mathrm{CDCl}_{3}\right): \delta$ $1.41-1.52(\mathrm{~m}, 1 \mathrm{H}), 1.44(\mathrm{~s}, 9 \mathrm{H}), 1.58-1.73(\mathrm{~m}, 2 \mathrm{H}), 1.87-1.94(\mathrm{~m}$, $1 \mathrm{H}), 2.68(\mathrm{tt}, J=12.8,2.9 \mathrm{~Hz}, 1 \mathrm{H}), 2.72-2.82(\mathrm{~m}, 1 \mathrm{H}), 2.86(\mathrm{t}, J=$ $11.7 \mathrm{~Hz}, 1 \mathrm{H}), 3.17(\mathrm{~s}, 3 \mathrm{H}), 3.72(\mathrm{~s}, 3 \mathrm{H}), 4.05-4.15(\mathrm{~m}, 2 \mathrm{H})$.

( \pm )-tert-Butyl 3-Formylpiperidine-1-carboxylate (8). Synthesis of aldehyde $\mathbf{8}$ was carried out following the procedure described for compound 3, starting from amide 7 (9.74 g, 35.76 mmol, 1.0 equiv). Yield: $79 \%$ (6.03 g); pale yellow oil.

(士)-tert-Butyl 3-(4-Fluorostyryl)piperidine-1-carboxylate [Isomers (Z)-9 and (E)-10]. Synthesized from 8 (1.02 g, 4.78 mmol, 1.0 equiv), (4-fluorobenzyl)triphenylphosphonium bromide $(2.59 \mathrm{~g}, 5.74 \mathrm{mmol}, 1.2$ equiv), and NaHMDS ( $2 \mathrm{~N}$ in THF, $2.87 \mathrm{~mL}$, $5.74 \mathrm{mmol}, 1.2$ equiv) via general procedure B. Column chromatography, petroleum ether $/ \mathrm{Et}_{2} \mathrm{O}=10 / 1(\mathrm{v} / \mathrm{v})$ yielding pure trans isomer $10(<8 \%$ cis isomer 9 was present in the mixture as estimated from ${ }^{1} \mathrm{H}$ NMR). Overall yield of reaction (mixture of $E / Z$ isomers): $56 \%(0.817 \mathrm{~g})$.

10: $R_{f}=0.38\left(\mathrm{Et}_{2} \mathrm{O} /\right.$ petroleum ether $\left.=1 / 10, \mathrm{v} / \mathrm{v}\right)$; yellow oil. ${ }^{1} \mathrm{H}$ NMR (400 MHz, $\mathrm{CDCl}_{3}, E$ isomer): $\delta 1.31-1.41(\mathrm{~m}, 1 \mathrm{H}), 1.47(\mathrm{~s}$, $9 \mathrm{H}), 1.68-1.73(\mathrm{~m}, 1 \mathrm{H}), 1.90-1.94(\mathrm{~m}, 1 \mathrm{H}), 2.26-2.34(\mathrm{~m}, 1 \mathrm{H})$, $2.60-2.71(\mathrm{~m}, 1 \mathrm{H}), 2.78(\mathrm{dd}, J=13.2,11.5 \mathrm{~Hz}, 2 \mathrm{H}), 3.97(\mathrm{~d}, J=13.1$ $\mathrm{Hz}, 2 \mathrm{H}), 5.99$ (dd, $J=16.0,7.0 \mathrm{~Hz}, 1 \mathrm{H}), 6.40(\mathrm{~d}, J=16.0 \mathrm{~Hz}, 1 \mathrm{H})$, 6.95-7.02 (m, 2H), 7.27-7.32 (m, 2H). HRMS (ESI+): $\mathrm{m} / z$ calcd for $\mathrm{C}_{18} \mathrm{H}_{24} \mathrm{FNO}_{2} \mathrm{Na}[\mathrm{M}+\mathrm{Na}]^{+} 328.1689$; found 328.1682 .

(士)-tert-Butyl 3-(2,4,5-Trifluorostyryl)piperidine-1-carboxylate [lsomers $(Z)-11$ and $(E)-12$ ]. Synthesized from $8(0.79 \mathrm{~g}, 3.71$ mmol, 1.0 equiv), (2,4,5-trifluorobenzyl)triphenylphosphonium bromide (2.23 g, $4.58 \mathrm{mmol}, 1.2$ equiv), and NaHMDS ( $2 \mathrm{~N}$ in THF, $2.29 \mathrm{~mL}, 4.58 \mathrm{mmol}, 1.2$ equiv) via general procedure B. Column chromatography, petroleum ether $/ \mathrm{Et}_{2} \mathrm{O}=10 / 1(\mathrm{v} / \mathrm{v})$ to obtain a mixture of cis/trans isomers (ratio $\sim 40 / 60$, estimated from ${ }^{1} \mathrm{H} N M R$ ). Overall yield of reaction: $47 \%$ (mass of both $Z$ and $E$ isomers, 0.595 g).

11 and 12 (mixture of both isomers): $R_{f}=0.34$ (petroleum ether/ $\left.\mathrm{Et}_{2} \mathrm{O}=10 / 1, \mathrm{v} / \mathrm{v}\right)$; yellow oil. ${ }^{1} \mathrm{H} \mathrm{NMR}\left(400 \mathrm{MHz}, \mathrm{CDCl}_{3}\right): \delta 1.30-$ $1.40(\mathrm{~m}, 3.4 \mathrm{H}), 1.45(1.46)(\mathrm{s}+\mathrm{s}, 15.3 \mathrm{H}), 1.62-1.73(\mathrm{~m}, 1.7 \mathrm{H})$, $1.88-1.94(\mathrm{~m}, 0.7 \mathrm{H}), 2.30-2.38(\mathrm{~m}, 0.7 \mathrm{H}), 2.43-2.53(\mathrm{~m}, 1 \mathrm{H})$, $2.62-2.84(\mathrm{~m}, 3.4 \mathrm{H}), 3.92-4.08(\mathrm{~m}, 3.4 \mathrm{H}), 5.58(\mathrm{dd}, J=11.5,10.4$ $\mathrm{Hz}, 0.7 \mathrm{H}), 6.07(\mathrm{dd}, J=16.2,7.1 \mathrm{~Hz}, 1 \mathrm{H}), 6.32(\mathrm{~d}, J=11.5 \mathrm{~Hz}$, $0.7 \mathrm{H}), 6.49(\mathrm{~d}, J=16.3 \mathrm{~Hz}, 1 \mathrm{H}), 6.85-6.96(\mathrm{~m}, 1.7 \mathrm{H}), 7.11(\mathrm{ddd}, J=$ $10.6,8.8,6.9 \mathrm{~Hz}, 1 \mathrm{H}), 7.21$ (ddd, $J=11.2,8.7,7.0 \mathrm{~Hz}, 0.7 \mathrm{H})$. HRMS (ESI+): $m / z$ calcd for $\mathrm{C}_{18} \mathrm{H}_{22} \mathrm{~F}_{3} \mathrm{NO}_{2} \mathrm{Na}[\mathrm{M}+\mathrm{Na}]^{+} 364.1500$; found 364.1491.

tert-Butyl 4-(2,4,5-Trifluorostyryl)piperidine-1-carboxylate [Isomers (Z)-13 and (E)-14]. Synthesized from aldehyde 3 (0.575 g, $2.70 \mathrm{mmol}, 1.0$ equiv), (2,4,5-trifluorobenzyl)triphenyl- phosphonium bromide ( $1.59 \mathrm{~g}, 3.25 \mathrm{mmol}, 1.2$ equiv) and NaHMDS ( $2 \mathrm{~N}$ solution in THF, $1.63 \mathrm{~mL}, 3.25 \mathrm{mmol}, 1.2$ equiv) via general procedure $\mathrm{B}$. Column chromatography, petroleum ether $/ \mathrm{Et}_{2} \mathrm{O}=10 / 1$ (v/v). Overall yield of reaction: $52 \%$ (mass of both $Z$ and $E$ isomers, $0.48 \mathrm{~g}$ ); isolated pure $Z$ isomer, $165 \mathrm{mg}$; isolated pure $E$ isomer, 135 $\mathrm{mg}$; mixture of $E / Z$ isomers, $180 \mathrm{mg}$.

13: $R_{f}=0.80($ EtOAc/n-hex $=1 / 2, \mathrm{v} / \mathrm{v})$; yellow crystals, mp 86$87^{\circ} \mathrm{C} .{ }^{1} \mathrm{H}$ NMR $\left(400 \mathrm{MHz}, \mathrm{CDCl}_{3}\right): \delta 1.30-1.40(\mathrm{~m}, 2 \mathrm{H}), 1.46(\mathrm{~s}$, $9 \mathrm{H}), 1.58-1.64(\mathrm{~m}, 2 \mathrm{H}), 2.37-2.48(\mathrm{~m}, 1 \mathrm{H}), 2.70(\mathrm{dt}, J=13.4,2.7$ $\mathrm{Hz}, 2 \mathrm{H}), 4.08(\mathrm{td}, J=13.4,2.7 \mathrm{~Hz}, 2 \mathrm{H}), 5.55(\mathrm{dd}, J=11.4,10.3 \mathrm{~Hz}$, $1 \mathrm{H}), 6.17(\mathrm{~d}, J=11.6 \mathrm{~Hz}, 1 \mathrm{H}), 6.93(\mathrm{ddd}, J=10.1,9.2,6.7 \mathrm{~Hz}, 1 \mathrm{H})$, 7.01 (ddd, $J=10.6,8.7,6.9 \mathrm{~Hz}, 1 \mathrm{H}$ ). HRMS (ESI +$): \mathrm{m} / z$ calcd for $\mathrm{C}_{18} \mathrm{H}_{22} \mathrm{~F}_{3} \mathrm{NO}_{2} \mathrm{Na}[\mathrm{M}+\mathrm{Na}]^{+}$364.1500; found 364.1503.

14: $R_{f}=0.78($ EtOAc/n-hex $=1 / 2, \mathrm{v} / \mathrm{v})$; pale yellow crystals, $\mathrm{mp}$ 60-63 ${ }^{\circ} \mathrm{C} .{ }^{1} \mathrm{H}$ NMR $\left(400 \mathrm{MHz}, \mathrm{CDCl}_{3}\right): \delta 1.36(\mathrm{dt}, J=12.4,4.2 \mathrm{~Hz}$, $1 \mathrm{H}), 1.39(\mathrm{dt}, J=12.3,4.3 \mathrm{~Hz}, 1 \mathrm{H}), 1.47(\mathrm{~s}, 9 \mathrm{H}), 1.71-1.79(\mathrm{~m}$, $2 \mathrm{H}), 2.25-2.36(\mathrm{~m}, 1 \mathrm{H}), 2.78(\mathrm{t}, J=12.0 \mathrm{~Hz}, 2 \mathrm{H}), 4.14(\mathrm{bs}, 2 \mathrm{H})$, $6.13(\mathrm{dd}, J=16.1,6.9 \mathrm{~Hz}, 1 \mathrm{H}), 6.44(\mathrm{~d}, J=16.1 \mathrm{~Hz}, 1 \mathrm{H}), 6.88(\mathrm{dt}, J$ $=9.9,6.6 \mathrm{~Hz}, 1 \mathrm{H}), 7.01(\mathrm{ddd}, J=11.1,8.8,7.0 \mathrm{~Hz}, 1 \mathrm{H})$. HRMS (ESI $+): m / z$ calcd for $\mathrm{C}_{18} \mathrm{H}_{22} \mathrm{~F}_{3} \mathrm{NO}_{2} \mathrm{Na}[\mathrm{M}+\mathrm{Na}]^{+} 364.1500$; found 364.1497.

(士)-tert-Butyl 3-(4-Fluorophenethyl)piperidine-1-carboxylate (15). Synthesized from a mixture of 9 and 10 (0.55 g, 1.80 mmol, 1.0 equiv) via general procedure $\mathrm{C}$. Yield: quantitative $(0.55$ g); yellow oil. ${ }^{1} \mathrm{H}$ NMR $\left(400 \mathrm{MHz}, \mathrm{CDCl}_{3}\right): \delta 1.08-1.13(\mathrm{~m}, 1 \mathrm{H})$, $1.35-1.56(\mathrm{~m}, 3 \mathrm{H}), 1.45(\mathrm{~s}, 9 \mathrm{H}), 1.59-1.66(\mathrm{~m}, 1 \mathrm{H}), 1.80-1.87(\mathrm{~m}$, $1 \mathrm{H}), 2.41-2.56(\mathrm{~m}, 1 \mathrm{H}), 2.61(\mathrm{t}, J=12.2 \mathrm{~Hz}, 2 \mathrm{H}), 2.79(\mathrm{dt}, J=12.2$, $2.5 \mathrm{~Hz}, 2 \mathrm{H}), 3.89(\mathrm{td}, J=13.1,3.9 \mathrm{~Hz}, 1 \mathrm{H}), 4.04(\mathrm{bs}, 1 \mathrm{H}), 6.92-6.98$ $(\mathrm{m}, 2 \mathrm{H}), 7.09-7.14(\mathrm{~m}, 2 \mathrm{H})$. HRMS (ESI $): \mathrm{m} / z$ calcd for $\mathrm{C}_{18} \mathrm{H}_{26} \mathrm{FNO}_{2} \mathrm{Na}[\mathrm{M}+\mathrm{Na}]^{+}$330.1845; found 330.1842.

( \pm )-tert-Butyl 3-(2,4,5-Trifluorophenethyl)piperidine-1-carboxylate (16). Synthesized from a mixture of 11 and $\mathbf{1 2}(0.30 \mathrm{~g}, 0.88$ mmol, 1.0 equiv) via general procedure C. Yield: $97 \%(0.29 \mathrm{~g})$; yellow oil. ${ }^{1} \mathrm{H}$ NMR (400 MHz, $\left.\mathrm{CDCl}_{3}\right): \delta 1.09-1.18(\mathrm{~m}, 1 \mathrm{H}), 1.37-1.55$ (m, 4H), $1.47(\mathrm{~s}, 9 \mathrm{H}), 1.62-1.69(\mathrm{~m}, 1 \mathrm{H}), 1.83-1.90(\mathrm{~m}, 1 \mathrm{H}), 2.55$ (dd, $J=13.0,9.3 \mathrm{~Hz}, 1 \mathrm{H}), 2.62(\mathrm{t}, J=7.6 \mathrm{~Hz}, 2 \mathrm{H}), 2.82(\mathrm{ddd}, J=$ $13.2,11.2,3.2 \mathrm{~Hz}, 1 \mathrm{H}), 3.89(\mathrm{td}, J=13.2,4.1 \mathrm{~Hz}, 1 \mathrm{H}), 3.97(\mathrm{~d}, J=$ $12.6 \mathrm{~Hz}, 1 \mathrm{H}), 6.88$ (ddd, $J=10.1,9.3,6.7 \mathrm{~Hz}, 1 \mathrm{H}), 7.00$ (ddd, $J=$ $10.6,8.7,6.9 \mathrm{~Hz}, 1 \mathrm{H}$ ). HRMS (ESI+): $m / z$ calcd for $\mathrm{C}_{18} \mathrm{H}_{24} \mathrm{~F}_{3} \mathrm{NO}_{2} \mathrm{Na}$ $[\mathrm{M}+\mathrm{Na}]^{+} 366.1657$; found 366.1653 .

tert-Butyl 4-(4-Fluorophenethyl)piperidine-1-carboxylate (17). Synthesized from a mixture of 4 and $5(0.152 \mathrm{~g}, 0.50 \mathrm{mmol}$, 1.0 equiv) via general procedure $C$. Yield: quantitative $(0.155 \mathrm{~g})$; yellow oil. ${ }^{1} \mathrm{H}$ NMR $\left(400 \mathrm{MHz}, \mathrm{CDCl}_{3}\right): \delta 1.11(\mathrm{dt}, J=12.4,4.2 \mathrm{~Hz}$, $1 \mathrm{H}), 1.14(\mathrm{dt}, J=12.5,4.2 \mathrm{~Hz}, 1 \mathrm{H}), 1.35-1.44(\mathrm{~m}, 1 \mathrm{H}), 1.45(\mathrm{~s}$, $9 \mathrm{H}), 1.51-1.56(\mathrm{~m}, 2 \mathrm{H}), 1.60-1.62(\mathrm{~m}, 1 \mathrm{H}), 1.65-1.72(\mathrm{~m}, 2 \mathrm{H})$, $2.57-2.62(\mathrm{~m}, 1 \mathrm{H}), 2.66(\mathrm{t}, J=11.5 \mathrm{~Hz}, 2 \mathrm{H}), 4.07(\mathrm{bs}, 2 \mathrm{H}), 6.93-$ $6.99(\mathrm{~m}, 2 \mathrm{H}), 7.09-7.14(\mathrm{~m}, 2 \mathrm{H})$. HRMS (ESI $): \mathrm{m} / z$ calcd for $\mathrm{C}_{18} \mathrm{H}_{26} \mathrm{FNO}_{2} \mathrm{Na}[\mathrm{M}+\mathrm{Na}]^{+} 330.1845$; found 330.1848 .

tert-Butyl 4-(2,4,5-Trifluorophenethyl)piperidine-1-carboxylate (18). Synthesized from a mixture of 13 and 14 (0.152 g, 0.45 mmol, 1.0 equiv) via general procedure $C$. Yield: quantitative $(0.155$ g); yellow oil. ${ }^{1} \mathrm{H}$ NMR (400 MHz, $\left.\mathrm{CDCl}_{3}\right): \delta 1.11(\mathrm{dt}, J=12.4,4.3$ $\mathrm{Hz}, 1 \mathrm{H}), 1.14(\mathrm{dt}, J=12.7,4.2 \mathrm{~Hz}, 1 \mathrm{H}), 1.35-1.44(\mathrm{~m}, 1 \mathrm{H}), 1.45$ (s, $9 \mathrm{H}), 1.49-1.54(\mathrm{~m}, 2 \mathrm{H}), 1.66-1.73(\mathrm{~m}, 2 \mathrm{H}), 2.59(\mathrm{t}, J=8.0 \mathrm{~Hz}$, $2 \mathrm{H}), 2.66(\mathrm{dt}, J=13.2,2.5 \mathrm{~Hz}, 2 \mathrm{H}), 4.09(\mathrm{~d}, J=13.2 \mathrm{~Hz}, 2 \mathrm{H}), 6.87$ (ddd, $J=10.0,9.4,6.7 \mathrm{~Hz}, 1 \mathrm{H}), 6.97$ (ddd, $J=10.6,8.8,7.1 \mathrm{~Hz}, 1 \mathrm{H})$. HRMS (ESI+): $m / z$ calcd for $\mathrm{C}_{18} \mathrm{H}_{24} \mathrm{~F}_{3} \mathrm{NO}_{2} \mathrm{Na}[\mathrm{M}+\mathrm{Na}]^{+} 366.1657$; found 366.1652 .

(士)-(E)-3-(4-Fluorostyryl)-1-(prop-2-yn-1-yl)piperidine (19). Synthesized from a mixture of 9 and $10(0.190 \mathrm{~g}, 2.11 \mathrm{mmol}, 1.0$ equiv) via general procedures $\mathrm{D}$ and $\mathrm{E}$. Column chromatography, EtOAc/n-hex $=1 / 1(\mathrm{v} / \mathrm{v})$ yielding pure trans isomer 19. Yield: $45 \%$ $(68 \mathrm{mg})$; yellow oil. ${ }^{1} \mathrm{H}$ NMR $\left(400 \mathrm{MHz}, \mathrm{CDCl}_{3}\right): \delta 1.17(\mathrm{dt}, J=$ $12.3,4.1 \mathrm{~Hz}, 1 \mathrm{H}), 1.61-1.72(\mathrm{~m}, 1 \mathrm{H}), 1.74-1.80(\mathrm{~m}, 1 \mathrm{H}), 1.81-$ $1.87(\mathrm{~m}, 1 \mathrm{H}), 2.09(\mathrm{t}, J=10.8 \mathrm{~Hz}, 1 \mathrm{H}), 2.19(\mathrm{dt}, J=11.4,3.0 \mathrm{~Hz}$, $1 \mathrm{H}), 2.25(\mathrm{t}, J=2.4 \mathrm{~Hz}, 1 \mathrm{H}), 2.41-2.50(\mathrm{~m}, 1 \mathrm{H}), 2.82-2.87(\mathrm{~m}$, $1 \mathrm{H}), 2.89-2.93(\mathrm{~m}, 1 \mathrm{H}), 3.34(\mathrm{~d}, J=2.5 \mathrm{~Hz}, 2 \mathrm{H}), 6.04(\mathrm{dd}, J=16.0$, $7.2 \mathrm{~Hz}, 1 \mathrm{H}), 6.38(\mathrm{~d}, J=16.0 \mathrm{~Hz}, 1 \mathrm{H}), 6.95-7.01(\mathrm{~m}, 2 \mathrm{H}), 7.28-$ $7.33(\mathrm{~m}, 2 \mathrm{H}) .{ }^{13} \mathrm{C}$ NMR $\left(100 \mathrm{MHz}, \mathrm{CDCl}_{3}\right): \delta 24.64,29.94,39.41$, 
47.18, 52.23, 57.76, 73.97, 77.87, $115.34\left(\mathrm{~d}, J_{\mathrm{C}, \mathrm{F}}=21.7 \mathrm{~Hz}\right), 127.47$ $\left(\mathrm{d}, J_{\mathrm{C}, \mathrm{F}}=8.0 \mathrm{~Hz}\right), 128.41,131.95,133.50\left(\mathrm{~d}, J_{\mathrm{C}, \mathrm{F}}=3.3 \mathrm{~Hz}\right), 162.03$ $\left(\mathrm{d}, J_{\mathrm{C}, \mathrm{F}}=246.0 \mathrm{~Hz}\right)$. HRMS (ESI +$): m / z$ calcd for $\mathrm{C}_{16} \mathrm{H}_{19} \mathrm{FN}[\mathrm{M}+$ $\mathrm{H}]^{+}$244.1502; found 244.1509. IR (ATR): 3433, 3196, 2934, 2544, $2124,1507,1225,1159,1012,858,750,647 \mathrm{~cm}^{-1}$. HPLC purity, $99.4 \%\left(t_{\mathrm{R}}=9.10 \mathrm{~min}\right)$.

(士)-(E)-1-(Prop-2-yn-1-yl)-3-(2,4,5-trifluorostyryl)piperidine (20). Synthesized from a mixture of 11 and $12(0.219 \mathrm{~g}, 0.64 \mathrm{mmol}$, 1.0 equiv) via general procedures $\mathrm{D}$ and $\mathrm{E}$. Column chromatography, EtOAc/n-hex $=1 / 1(\mathrm{v} / \mathrm{v})$ to obtain pure trans isomer 20. Yield: $34 \%$ $(61 \mathrm{mg})$; yellow oil. ${ }^{1} \mathrm{H}$ NMR $\left(400 \mathrm{MHz}, \mathrm{CDCl}_{3}\right): \delta 1.21$ (ddd, $J=$ $15.8,12.1,4.1 \mathrm{~Hz}, 1 \mathrm{H}), 1.63-1.87(\mathrm{~m}, 3 \mathrm{H}), 2.13(\mathrm{t}, J=10.7 \mathrm{~Hz}, 1 \mathrm{H})$, $2.24(\mathrm{dt}, J=11.2,2.6 \mathrm{~Hz}, 1 \mathrm{H}), 2.27(\mathrm{t}, J=2.4 \mathrm{~Hz}, 1 \mathrm{H}), 2.47-2.56$ $(\mathrm{m}, 1 \mathrm{H}), 2.84-2.87(\mathrm{~m}, 1 \mathrm{H}), 2.90-2.94(\mathrm{~m}, 1 \mathrm{H}), 3.36(\mathrm{~d}, J=2.4 \mathrm{~Hz}$, $2 \mathrm{H}), 6.12(\mathrm{dd}, J=16.1,7.2 \mathrm{~Hz}, 1 \mathrm{H}), 6.46(\mathrm{~d}, J=16.2 \mathrm{~Hz}, 1 \mathrm{H}), 6.88$ $(\mathrm{dt}, J=9.9,6.7 \mathrm{~Hz}, 1 \mathrm{H}), 7.22(\mathrm{ddd}, J=11.1,8.8,7.0 \mathrm{~Hz}, 1 \mathrm{H}) .{ }^{13} \mathrm{C}$ NMR $\left(100 \mathrm{MHz}, \mathrm{CDCl}_{3}\right): \delta 24.77,29.89,39.90,47.28,52.32,57.64$, 73.44, 78.51, $105.56\left(\mathrm{dd}, J_{\mathrm{C}, \mathrm{F}}=28.4,21.0 \mathrm{~Hz}\right), 114.14\left(\mathrm{dd}, J_{\mathrm{C}, \mathrm{F}}=\right.$ $19.8,5.1 \mathrm{~Hz}), 120.01-120.02(\mathrm{~m}), 121.74-121.93(\mathrm{~m}), 136.12-$ $136.16(\mathrm{~m}), 146.93\left(\mathrm{ddd}, J_{\mathrm{C}, \mathrm{F}}=243.9,13.2,3.6 \mathrm{~Hz}\right), 148.83\left(\mathrm{ddd}, J_{\mathrm{C}, \mathrm{F}}\right.$ $=251.2,14.8,12.4 \mathrm{~Hz}), 154.78\left(\mathrm{ddd}, J_{\mathrm{C}, \mathrm{F}}=248.0,9.0,2.1 \mathrm{~Hz}\right)$. IR (ATR): 3304, 2932, 2798, 1621, 1512, 1427, 1336, 1154, 1106, 969, $879,850,665 \mathrm{~cm}^{-1}$. HRMS (ESI+): $\mathrm{m} / z$ calcd for $\mathrm{C}_{16} \mathrm{H}_{17} \mathrm{~F}_{3} \mathrm{~N}[\mathrm{M}+$ $\mathrm{H}]^{+}$280.1313; found 280.1316. HPLC purity, $99.1 \%\left(t_{\mathrm{R}}=9.57 \mathrm{~min}\right)$.

(Z)-1-(Prop-2-yn-1-yl)-4-(2,4,5-trifluorostyryl)piperidine (21). Synthesized from 13 (165 mg, $0.483 \mathrm{mmol}, 1.0$ equiv) via general procedures $\mathrm{D}$ and $\mathrm{E}$. Column chromatography, EtOAc/n-hex $=1 / 1(\mathrm{v} / \mathrm{v})$. Yield: $68 \%(92 \mathrm{mg})$; white crystals, mp $72-74{ }^{\circ} \mathrm{C} .{ }^{1} \mathrm{H}$ NMR (400 MHz, CDCl $): \delta 1.55(\mathrm{dt}, J=12.5,3.8 \mathrm{~Hz}, 1 \mathrm{H}), 1.58(\mathrm{dt}$, $J=11.7,3.8 \mathrm{~Hz}, 1 \mathrm{H}), 1.66-1.71(\mathrm{~m}, 2 \mathrm{H}), 2.20-2.35(\mathrm{~m}, 3 \mathrm{H}), 2.25$ $(\mathrm{t}, J=2.5 \mathrm{~Hz}, 1 \mathrm{H}) 2.90(\mathrm{dt}, J=11.6,2.8 \mathrm{~Hz}, 2 \mathrm{H}), 3.32(\mathrm{~d}, J=2.4 \mathrm{~Hz}$, $2 \mathrm{H}), 5.64(\mathrm{dd}, J=11.3,10.4 \mathrm{~Hz}, 1 \mathrm{H}), 6.23(\mathrm{~d}, J=11.6 \mathrm{~Hz}, 1 \mathrm{H}), 6.92$ (ddd, $J=10.0,9.3,6.7 \mathrm{~Hz}, 1 \mathrm{H}), 7.01(\mathrm{ddd}, J=10.6,8.8,6.9 \mathrm{~Hz}, 1 \mathrm{H})$. ${ }^{13} \mathrm{C}$ NMR $\left(100 \mathrm{MHz}, \mathrm{CDCl}_{3}\right): \delta 31.77,34.96,47.19,51.71,73.33$, $78.62,105.51\left(\mathrm{dd}, J_{\mathrm{C}, \mathrm{F}}=28.7,20.7 \mathrm{~Hz}\right), 117.62\left(\mathrm{dd}, J_{\mathrm{C}, \mathrm{F}}=19.4,4.6\right.$ $\mathrm{Hz}$ ), 119.00, 121.36 (ddd, $\left.J_{\mathrm{C}, \mathrm{F}}=17.7,5.8,4.4 \mathrm{~Hz}\right), 140.20,146.36$ $\left(\right.$ ddd, $\left.J_{\mathrm{C}, \mathrm{F}}=243.7,12.6,3.6 \mathrm{~Hz}\right), 148.88\left(\mathrm{ddd}, J_{\mathrm{C}, \mathrm{F}}=248.8,14.4,12.6\right.$ $\mathrm{Hz}$ ); 154.97 (ddd, $J_{\mathrm{C}, \mathrm{F}}=246.8,9.0,2.7 \mathrm{~Hz}$ ). HRMS (ESI+): $\mathrm{m} / z$ calcd for $\mathrm{C}_{16} \mathrm{H}_{17} \mathrm{~F}_{3} \mathrm{~N}[\mathrm{M}+\mathrm{H}]^{+}$280.1313; found 280.1317. IR (ATR): 3293, 2905, 2824, 1618, 1503, 1423, 1310, 1192, 1151, 1133, 972, $882,779,679,653 \mathrm{~cm}^{-1}$. HPLC purity, $100 \%\left(t_{\mathrm{R}}=9.47 \mathrm{~min}\right)$.

(E)-1-(Prop-2-yn-1-yl)-4-(2,4,5-trifluorostyryl)piperidine (22). Synthesized from 14 (0.135 g, $0.395 \mathrm{mmol}, 1.0$ equiv) via general procedures D and E. Column chromatography, EtOAc/n-hex $=1 / 1(\mathrm{v} / \mathrm{v})$. Yield: $74 \%(82 \mathrm{mg})$; yellow oil. ${ }^{1} \mathrm{H}$ NMR $(400 \mathrm{MHz}$, $\left.\mathrm{CDCl}_{3}\right): \delta 1.56(\mathrm{dt}, J=12.4,3.4 \mathrm{~Hz}, 1 \mathrm{H}), 1.59(\mathrm{dt}, J=12.0,3.7 \mathrm{~Hz}$, $1 \mathrm{H}), 1.78-1.84(\mathrm{~m}, 2 \mathrm{H}), 2.11-2.20(\mathrm{~m}, 1 \mathrm{H}), 2.26(\mathrm{t}, J=2.4 \mathrm{~Hz}$, $1 \mathrm{H}), 2.30(\mathrm{dt}, J=11.7,2.3 \mathrm{~Hz}, 2 \mathrm{H}), 2.95(\mathrm{dt}, J=11.6,2.8 \mathrm{~Hz}, 2 \mathrm{H})$, $3.34(\mathrm{~d}, J=2.4 \mathrm{~Hz}, 2 \mathrm{H}), 6.13(\mathrm{dd}, J=16.1,7.0 \mathrm{~Hz}, 1 \mathrm{H}), 6.43(\mathrm{~d}, J=$ $16.1 \mathrm{~Hz}, 1 \mathrm{H}), 6.87(\mathrm{dt}, J=9.9,6.7 \mathrm{~Hz}, 1 \mathrm{H}), 7.23(\mathrm{ddd}, J=11.1,8.8$, $7.0 \mathrm{~Hz}, 1 \mathrm{H}) .{ }^{13} \mathrm{C}$ NMR $\left(100 \mathrm{MHz}, \mathrm{CDCl}_{3}\right): \delta 31.69,39.02,47.17$, $52.07,73.23,78.73,105.51\left(\mathrm{dd}, J_{\mathrm{C}, \mathrm{F}}=28.5,20.9 \mathrm{~Hz}\right), 114.06\left(\mathrm{dd}, J_{\mathrm{C}, \mathrm{F}}\right.$ $=19.6,5.2 \mathrm{~Hz}), 118.96-119.03(\mathrm{~m}), 121.95\left(\mathrm{ddd}, J_{\mathrm{C}, \mathrm{F}}=14.8,5.8,4.4\right.$ $\mathrm{Hz}), 138.10-138.17(\mathrm{~m}), 146.93\left(\mathrm{ddd}, J_{\mathrm{C}, \mathrm{F}}=243.5,12.9,3.4 \mathrm{~Hz}\right)$, $148.76\left(\mathrm{ddd}, J_{\mathrm{C}, \mathrm{F}}=251.1,14.9,12.6 \mathrm{~Hz}\right) ; 154.73\left(\mathrm{ddd}, J_{\mathrm{C}, \mathrm{F}}=247.4\right.$, 9.1, $2.3 \mathrm{~Hz}$ ). HRMS (ESI+): $m / z$ calcd for $\mathrm{C}_{16} \mathrm{H}_{17} \mathrm{~F}_{3} \mathrm{~N}[\mathrm{M}+\mathrm{H}]^{+}$ 280.1313; found 280.1318. IR (ATR): 3305, 3180, 2931, 2804, 2513, $1619,1510,1426,1335,1150,1107,970,878,706,630 \mathrm{~cm}^{-1}$. HPLC purity, $100 \%\left(t_{\mathrm{R}}=9.57 \mathrm{~min}\right)$.

( \pm )-3-(4-Fluorophenethyl)-1-(prop-2-yn-1-yl)piperidine (23). Synthesized from 15 (0.193 g, $0.628 \mathrm{mmol}, 1.0$ equiv) via general procedures D and E. Column chromatography, EtOAc/n-hex $=1 / 1(\mathrm{v} / \mathrm{v})$. Yield: $33 \%(51 \mathrm{mg})$; yellow oil. ${ }^{1} \mathrm{H}$ NMR $(400 \mathrm{MHz}$, $\left.\mathrm{CDCl}_{3}\right): \delta 0.85-0.95(\mathrm{~m}, 1 \mathrm{H}), 1.46-1.54(\mathrm{~m}, 2 \mathrm{H}), 1.55-1.65(\mathrm{~m}$, $2 \mathrm{H}), 1.66-1.74(\mathrm{~m}, 1 \mathrm{H}), 1.75-1.82(\mathrm{~m}, 1 \mathrm{H}), 1.88(\mathrm{t}, J=10.6 \mathrm{~Hz}$, $1 \mathrm{H}), 2.14(\mathrm{dt}, J=11.4,3.0 \mathrm{~Hz}, 1 \mathrm{H}), 2.24(\mathrm{t}, J=2.4 \mathrm{~Hz}, 1 \mathrm{H}), 2.60(\mathrm{t}, J$ $=7.9 \mathrm{~Hz}, 2 \mathrm{H}), 2.79-2.83(\mathrm{~m}, 1 \mathrm{H}), 2.84-2.89(\mathrm{~m}, 1 \mathrm{H}), 3.30(\mathrm{~d}, J=$ $2.4 \mathrm{~Hz}, 2 \mathrm{H}), 6.91-6.97(\mathrm{~m}, 2 \mathrm{H}), 7.09-7.14(\mathrm{~m}, 2 \mathrm{H}) .{ }^{13} \mathrm{C}$ NMR $(100$ $\left.\mathrm{MHz}, \mathrm{CDCl}_{3}\right): \delta 25.03,30.25,32.26,35.55,36.44,47.29,52.72$, $58.53,73.49,78.45,115.00\left(\mathrm{~d}, J_{\mathrm{C}, \mathrm{F}}=21.0 \mathrm{~Hz}\right), 129.54\left(\mathrm{~d}, J_{\mathrm{C}, \mathrm{F}}=7.9\right.$
$\mathrm{Hz}), 138.00\left(\mathrm{~d}, J_{\mathrm{C}, \mathrm{F}}=3.2 \mathrm{~Hz}\right), 161.13\left(\mathrm{~d}, J_{\mathrm{C}, \mathrm{F}}=243.3 \mathrm{~Hz}\right)$. HRMS (ESI+): $m / z$ calcd for $\mathrm{C}_{16} \mathrm{H}_{21} \mathrm{FN}[\mathrm{M}+\mathrm{H}]^{+}$246.1658; found 246.1652. IR (ATR): 3302, 2929, 2853, 2797, 1601, 1509, 1452, $1222,1157,1106,828,661 \mathrm{~cm}^{-1}$. HPLC purity, $98.5 \%\left(t_{\mathrm{R}}=9.16\right.$ $\min )$.

( \pm )-3-(2,4,5-Trifluorophenethyl)-1-(prop-2-yn-1-yl)piperidine (24). Synthesized from $16(0.181 \mathrm{~g}, 0.527 \mathrm{mmol}, 1.0$ equiv) via general procedures $\mathrm{D}$ and $\mathrm{E}$. Column chromatography, EtOAc/n-hex $=1 / 2(\mathrm{v} / \mathrm{v})$. Yield: $26 \%(39 \mathrm{mg})$; yellow oil. ${ }^{1} \mathrm{H}$ NMR $\left(400 \mathrm{MHz}, \mathrm{CDCl}_{3}\right): \delta 0.88-0.98(\mathrm{~m}, 1 \mathrm{H}), 1.45-1.56(\mathrm{~m}, 2 \mathrm{H})$, $1.58-1.77(\mathrm{~m}, 3 \mathrm{H}), 1.78-1.85(\mathrm{~m}, 1 \mathrm{H}), 1.91-2.00(\mathrm{~m}, 1 \mathrm{H}), 2.17-$ $2.25(\mathrm{~m}, 1 \mathrm{H}), 2.26-2.29(\mathrm{~m}, 1 \mathrm{H}), 2.54-2.66(\mathrm{~m}, 2 \mathrm{H}), 2.88(\mathrm{t}, J=$ $12.6 \mathrm{~Hz}, 2 \mathrm{H}), 3.35$ (d, $J=2.5 \mathrm{~Hz}, 2 \mathrm{H}), 6.86$ (ddd, $J=10.0,9.5,6.7$ $\mathrm{Hz}, 1 \mathrm{H}), 6.98$ (ddd, $J=10.6,8.8,6.9 \mathrm{~Hz}, 1 \mathrm{H}) .{ }^{13} \mathrm{C}$ NMR $(100 \mathrm{MHz}$ $\left.\mathrm{CDCl}_{3}\right): \delta 25.08,25.67,30.21,34.61,35.62,47.33,52.76,58.46$, $73.28,78.69,105.20\left(\mathrm{dd}, J_{\mathrm{C}, \mathrm{F}}=28.6,20.6 \mathrm{~Hz}\right), 117.71\left(\mathrm{dd}, J_{\mathrm{C}, \mathrm{F}}=\right.$ $18.7,6.2 \mathrm{~Hz}), 125.50\left(\mathrm{td}, J_{\mathrm{C}, \mathrm{F}}=18.1,4.4 \mathrm{~Hz}\right), 146.57\left(\mathrm{ddd}, J_{\mathrm{C}, \mathrm{F}}=\right.$ 243.7, 12.4, $3.7 \mathrm{~Hz}$ ), 148.14 (ddd, $\left.J_{\mathrm{C}, \mathrm{F}}=248.6,14.3,12.5 \mathrm{~Hz}\right), 155.73$ (ddd, $J_{\mathrm{CF}}=243.8,9.2,2.7 \mathrm{~Hz}$ ). HRMS (ESI+): $\mathrm{m} / z$ calcd for $\mathrm{C}_{16} \mathrm{H}_{19} \mathrm{~F}_{3} \mathrm{~N}[\mathrm{M}+\mathrm{H}]^{+}$282.1470; found 282.1464. IR (ATR): 3306, $2931,2798,1515,1422,1331,1209,1150,1100,843,659 \mathrm{~cm}^{-1}$. HPLC purity, $100 \%\left(t_{\mathrm{R}}=9.57 \mathrm{~min}\right)$.

4-(4-Fluorophenethyl)-1-(prop-2-yn-1-yl)piperidine (25). Synthesized from $17(0.130 \mathrm{~g}, 0.423 \mathrm{mmol}, 1.0$ equiv) via general procedures D and E. Column chromatography, EtOAc/n-hex $=1 / 1$ (v/v). Yield: $85 \%(88 \mathrm{mg})$; colorless oil. ${ }^{1} \mathrm{H}$ NMR $(400 \mathrm{MHz}$, $\left.\mathrm{CDCl}_{3}\right): \delta 1.21-1.40(\mathrm{~m}, 3 \mathrm{H}), 1.52-1.57(\mathrm{~m}, 2 \mathrm{H}), 1.73-1.79(\mathrm{~m}$, $2 \mathrm{H}), 2.19-2.24(\mathrm{~m}, 2 \mathrm{H}), 2.25(\mathrm{t}, J=2.4 \mathrm{~Hz}, 1 \mathrm{H}), 2.57-2.61(\mathrm{~m}$ $2 \mathrm{H}), 2.89-2.93(\mathrm{~m}, 2 \mathrm{H}), 3.33(\mathrm{~d}, J=2.4 \mathrm{~Hz}, 2 \mathrm{H}), 6.92-6.98(\mathrm{~m}$, $2 \mathrm{H}), 7.09-7.14(\mathrm{~m}, 2 \mathrm{H}) .{ }^{13} \mathrm{C}$ NMR $\left(100 \mathrm{MHz}, \mathrm{CDCl}_{3}\right): \delta 32.07$, $32.21,34.61,38.35,47.16,52.48,73.09,78.90,114.99\left(\mathrm{~d}, J_{\mathrm{C}, \mathrm{F}}=21.1\right.$ $\mathrm{Hz}), 129.54\left(\mathrm{~d}, J_{\mathrm{C}, \mathrm{F}}=7.9 \mathrm{~Hz}\right), 138.16\left(\mathrm{~d}, J_{\mathrm{C}, \mathrm{F}}=3.1 \mathrm{~Hz}\right), 161.11(\mathrm{~d}$, $\left.J_{\mathrm{C}, \mathrm{F}}=243.2 \mathrm{~Hz}\right)$. HRMS $(\mathrm{ESI}+): m / z$ calcd for $\mathrm{C}_{16} \mathrm{H}_{21} \mathrm{FN}[\mathrm{M}+\mathrm{H}]^{+}$ 246.1658; found 246.1657. IR (ATR): 3300, 2923, 1601, 1508, 1453, $1218,1156,824,642 \mathrm{~cm}^{-1}$. HPLC purity, $97.5 \%\left(t_{\mathrm{R}}=9.15 \mathrm{~min}\right)$.

1-(Prop-2-yn-1-yl)-4-(2,4,5-trifluorophenethyl)piperidine (26). Synthesized from 18 (0.175 g, $0.509 \mathrm{mmol}, 1.0$ equiv) via general procedures $\mathrm{D}$ and $\mathrm{E}$. Column chromatography, EtOAc/n-hex $=1 / 1(\mathrm{v} / \mathrm{v})$. Yield: $32 \%(45 \mathrm{mg})$; yellow oil. ${ }^{1} \mathrm{H}$ NMR $(400 \mathrm{MHz}$, $\left.\mathrm{CDCl}_{3}\right): \delta 1.22-1.39(\mathrm{~m}, 3 \mathrm{H}), 1.49-1.55(\mathrm{~m}, 2 \mathrm{H}), 1.72-1.79(\mathrm{~m}$, $2 \mathrm{H}), 2.17-2.23(\mathrm{~m}, 2 \mathrm{H}), 2.23-2.25(\mathrm{~m}, 1 \mathrm{H}), 2.59(\mathrm{t}, J=7.8 \mathrm{~Hz}$, $2 \mathrm{H}), 2.88-2.93(\mathrm{~m}, 2 \mathrm{H}), 3.30-3.32(\mathrm{~m}, 2 \mathrm{H}), 6.86$ (ddd, $J=10.0$, 9.5, $6.7 \mathrm{~Hz}, 1 \mathrm{H}), 6.97$ (ddd, $J=10.7,8.8,6.5 \mathrm{~Hz}, 1 \mathrm{H}) .{ }^{13} \mathrm{C}$ NMR $\left(100 \mathrm{MHz}, \mathrm{CDCl}_{3}\right): \delta 25.56,31.94,34.68,36.55,47.13,52.40,73.16$, 78.81, $105.18\left(\mathrm{dd}, J_{\mathrm{C}, \mathrm{F}}=28.7,20.6 \mathrm{~Hz}\right), 117.66\left(\mathrm{dd}, J_{\mathrm{C}, \mathrm{F}}=19.1,6.5\right.$ $\mathrm{Hz}), 125.50-125.82(\mathrm{~m}), 146.57$ (ddd, $J_{\mathrm{CF}}=243.6,12.6,3.2 \mathrm{~Hz}$ ), 148.09 (ddd, $\left.J_{\mathrm{C}, \mathrm{F}}=249.2,13.4,11.5 \mathrm{~Hz}\right) ; 155.72\left(\mathrm{ddd}, J_{\mathrm{C}, \mathrm{F}}=243.4\right.$, 9.3, $2.7 \mathrm{~Hz}$ ). HRMS (ESI+): $m / z$ calcd for $\mathrm{C}_{16} \mathrm{H}_{19} \mathrm{~F}_{3} \mathrm{~N}[\mathrm{M}+\mathrm{H}]^{+}$ 282.1470; found 282.1471. IR (ATR): 3306, 2920, 2803, 1517, 1423, $1334,1210,1151,1108,876,660 \mathrm{~cm}^{-1}$. HPLC purity, $100 \%\left(t_{\mathrm{R}}=\right.$ $9.63 \mathrm{~min})$.

Wittig Salts $(27 a-I)$. Synthesized according to general procedure A. The product was used in next reaction step without purification.

tert-Butyl 4-Styrylpiperidine-1-carboxylate [Isomers (Z)-28 and $(E)-29]$. Synthesized from aldehyde $3(2.00 \mathrm{~g}, 9.38 \mathrm{mmol}, 1.0$ equiv), benzyltriphenylphosphonium chloride $(4.01 \mathrm{~g}, 10.32 \mathrm{mmol}$, 1.1 equiv), and NaHMDS ( $2 \mathrm{~N}$ in THF, $5.63 \mathrm{~mL}, 11.26 \mathrm{mmol}, 1.2$ equiv) via general procedure $\mathrm{B}$. Column chromatography, petroleum ether $/ \mathrm{Et}_{2} \mathrm{O}=9 / 1(\mathrm{v} / \mathrm{v})$. Overall yield of reaction: $66 \%$ (mass of both $Z$ and $E$ isomers, $1.78 \mathrm{~g}$ ); isolated pure $Z$ isomer, $95 \mathrm{mg}$; isolated pure $E$ isomer, $285 \mathrm{mg}$; mixture of $E / Z$ isomers, $1.4 \mathrm{~g}$.

28: $R_{f}=0.31$ (petroleum ether $/ \mathrm{Et}_{2} \mathrm{O}=9 / 1, \mathrm{v} / \mathrm{v}$ ); colorless oil. ${ }^{1} \mathrm{H}$ NMR (400 MHz, $\mathrm{CDCl}_{3}$ ): $\delta 1.36$ (ddd, $J=17.1,13.9,5.3 \mathrm{~Hz}, 2 \mathrm{H}$ ), $1.46(\mathrm{~s}, 9 \mathrm{H}), 1.65-1.68(\mathrm{~m}, 2 \mathrm{H}), 2.68-2.76(\mathrm{~m}, 3 \mathrm{H}), 4.08(\mathrm{bs}, 2 \mathrm{H})$, $5.45(\mathrm{dd}, J=11.7,10.0 \mathrm{~Hz}, 1 \mathrm{H}), 6.39(\mathrm{~d}, J=11.7 \mathrm{~Hz}, 1 \mathrm{H}), 7.21-7.25$ (m, 3H), 7.31-7.35 (m, 2H). MS (ESI+): $m / z[\mathrm{M}+\mathrm{Na}]^{+} 310.18$; found 310.17 .

29: $R_{f}=0.28$ (petroleum ether $/ \mathrm{Et}_{2} \mathrm{O}=9 / 1, \mathrm{v} / \mathrm{v}$ ); colorless oil. ${ }^{1} \mathrm{H}$ $\operatorname{NMR}\left(400 \mathrm{MHz}, \mathrm{CDCl}_{3}\right): \delta 1.36$ (ddd, $\left.J=16.6,12.6,4.5 \mathrm{~Hz}, 2 \mathrm{H}\right)$, $1.47(\mathrm{~s}, 9 \mathrm{H}), 1.73-1.76(\mathrm{~m}, 2 \mathrm{H}), 2.22-2.31(\mathrm{~m}, 1 \mathrm{H}), 2.77(\mathrm{t}, J=$ 
$11.5 \mathrm{~Hz}, 2 \mathrm{H}), 4.12(\mathrm{bs}, 2 \mathrm{H}), 6.13(\mathrm{dd}, J=17.0,6.9 \mathrm{~Hz}, 1 \mathrm{H}), 6.38(\mathrm{~d}$, $J=16.0 \mathrm{~Hz}, 1 \mathrm{H}), 7.17-7.21(\mathrm{~m}, 1 \mathrm{H}), 7.27-7.35(\mathrm{~m}, 4 \mathrm{H})$. MS (ESI $+): m / z[\mathrm{M}+\mathrm{Na}]^{+} 310.18$; found 310.12 .

tert-Butyl 4-(3-Fluorostyryl)piperidine-1-carboxylate [Isomers $(Z)-30$ and $(E)-31]$. Synthesized from aldehyde $3(2.00 \mathrm{~g}$, $9.38 \mathrm{mmol}, 1.0$ equiv), $27 \mathrm{a}$ ( $4.20 \mathrm{~g}, 10.32 \mathrm{mmol}, 1.1 \mathrm{equiv})$, and NaHMDS ( $2 \mathrm{~N}$ in THF, $5.63 \mathrm{~mL}, 11.26 \mathrm{mmol}, 1.2$ equiv) via general procedure $\mathrm{B}$. Column chromatography, petroleum ether $/ \mathrm{Et}_{2} \mathrm{O}=10 / 1$ (v/v). Overall yield of reaction: $56 \%$ (mass of both $Z$ and $E$ isomers, $1.60 \mathrm{~g}$ ); isolated pure $Z$ isomer, $120 \mathrm{mg}$; isolated pure $E$ isomer, 355 $\mathrm{mg}$; mixture of $E / Z$ isomers, $1.125 \mathrm{~g}$.

30: $R_{f}=0.70($ EtOAc $/ \mathrm{n}-\mathrm{hex}=1 / 2, \mathrm{v} / \mathrm{v})$; pale yellow oil. ${ }^{1} \mathrm{H}$ NMR $\left(400 \mathrm{MHz}, \mathrm{CDCl}_{3}\right): \delta 1.35(\mathrm{dt}, J=12.4,3.9 \mathrm{~Hz}, 1 \mathrm{H}), 1.38(\mathrm{dt}, J=$ $12.2,3.7 \mathrm{~Hz}, 1 \mathrm{H}), 1.46(\mathrm{~s}, 9 \mathrm{H}), 1.60-1.69(\mathrm{~m}, 2 \mathrm{H}), 2.62-2.77(\mathrm{~m}$, $3 \mathrm{H}), 4.09$ (bs, 2H), $5.50(\mathrm{dd}, J=11.6,10.2 \mathrm{~Hz}, 1 \mathrm{H}), 6.35(\mathrm{~d}, J=11.6$ $\mathrm{Hz}, 1 \mathrm{H}), 6.91-6.97(\mathrm{~m}, 2 \mathrm{H}), 6.99-7.01(\mathrm{~m}, 1 \mathrm{H}), 7.27-7.32(\mathrm{~m}$, $1 \mathrm{H})$. MS (ESI+): $m / z[\mathrm{M}+\mathrm{Na}]^{+} 328.17$; found 328.42 .

31: $R_{f}=0.67($ EtOAc/n-hex $=1 / 2, \mathrm{v} / \mathrm{v})$; white crystals, mp 45-46 ${ }^{\circ} \mathrm{C} .{ }^{1} \mathrm{H}$ NMR $\left(400 \mathrm{MHz}, \mathrm{CDCl}_{3}\right): \delta 1.31-1.44(\mathrm{~m}, 2 \mathrm{H}), 1.47(\mathrm{~s}$, $9 \mathrm{H}), 1.71-1.78(\mathrm{~m}, 2 \mathrm{H}), 2.23-2.33(\mathrm{~m}, 1 \mathrm{H}), 2.78(\mathrm{t}, J=12.2 \mathrm{~Hz}$, $2 \mathrm{H}), 4.13(\mathrm{bs}, 2 \mathrm{H}), 6.15(\mathrm{dd}, J=16.0,6.8 \mathrm{~Hz}, 1 \mathrm{H}), 6.35(\mathrm{~d}, J=16.0$ $\mathrm{Hz}, 1 \mathrm{H}), 6.89$ (ddt, $J=8.4,2.6,0.9 \mathrm{~Hz}, 1 \mathrm{H}), 7.02-7.06(\mathrm{~m}, 1 \mathrm{H})$, $7.07-7.11(\mathrm{~m}, 1 \mathrm{H}), 7.25(\mathrm{td}, J=8.0,5.8 \mathrm{~Hz}, 1 \mathrm{H}) . \mathrm{MS}(\mathrm{ESI}+): \mathrm{m} / z$ $[\mathrm{M}+\mathrm{Na}]^{+}$328.17; found 328.40 .

tert-Butyl 4-(2-Fluorostyryl)piperidine-1-carboxylate [Isomers $(Z)-32$ and $(E)-33]$. Synthesized from aldehyde $3(1.50 \mathrm{~g}$, $7.04 \mathrm{mmol}, 1.0$ equiv), $27 \mathrm{~b}$ ( $3.49 \mathrm{~g}, 7.74 \mathrm{mmol}, 1.1$ equiv), and NaHMDS ( $2 \mathrm{~N}$ in THF, $4.22 \mathrm{~mL}, 8.45 \mathrm{mmol}, 1.2$ equiv) via general procedure $\mathrm{B}$. Column chromatography, petroleum ether $/ \mathrm{Et}_{2} \mathrm{O}=10 / 1$ (v/v). Overall yield of reaction: $58 \%$ (mass of both $Z$ and $E$ isomers, $1.25 \mathrm{~g}$ ); isolated pure $Z$ isomer, $252 \mathrm{mg}$; isolated pure $E$ isomer, 194 $\mathrm{mg}$; mixture of $E / Z$ isomers, $0.804 \mathrm{~g}$.

32: $R_{f}=0.16$ (petroleum ether $/ \mathrm{Et}_{2} \mathrm{O}=10 / 1, \mathrm{v} / \mathrm{v}$ ); colorless oil. ${ }^{1} \mathrm{H}$ NMR (400 MHz, CDCl $): \delta 1.27-1.40(\mathrm{~m}, 2 \mathrm{H}), 1.43(\mathrm{~s}, 9 \mathrm{H}), 1.56-$ $1.62(\mathrm{~m}, 2 \mathrm{H}), 2.44-2.54(\mathrm{~m}, 1 \mathrm{H}), 2.61-2.70(\mathrm{~m}, 2 \mathrm{H}), 4.09(\mathrm{bs}, 2 \mathrm{H})$, $5.53(\mathrm{dd}, J=11.6,10.2 \mathrm{~Hz}, 1 \mathrm{H}), 6.33(\mathrm{~d}, J=11.6 \mathrm{~Hz}, 1 \mathrm{H}), 6.96(\mathrm{ddd}$, $J=10.8,8.2,1.3 \mathrm{~Hz}, 1 \mathrm{H}), 7.00-7.10(\mathrm{~m}, 2 \mathrm{H}), 7.17-7.22(\mathrm{~m}, 1 \mathrm{H})$. MS (ESI+): $m / z[\mathrm{M}+\mathrm{Na}]^{+} 328.17$; found 328.42 .

33: $R_{f}=0.14$ (petroleum ether $/ \mathrm{Et}_{2} \mathrm{O}=10 / 1, \mathrm{v} / \mathrm{v}$ ); colorless oil. ${ }^{1} \mathrm{H}$ $\operatorname{NMR}\left(400 \mathrm{MHz}, \mathrm{CDCl}_{3}\right): \delta 1.36(\mathrm{dt}, J=12.3,4.2 \mathrm{~Hz}, 1 \mathrm{H}), 1.39(\mathrm{dt}$, $J=12.3,4.2 \mathrm{~Hz}, 1 \mathrm{H}), 1.46(\mathrm{~s}, 9 \mathrm{H}), 1.70-1.77(\mathrm{~m}, 2 \mathrm{H}), 2.23-2.33$ $(\mathrm{m}, 1 \mathrm{H}), 2.76(\mathrm{t}, J=11.0 \mathrm{~Hz}, 2 \mathrm{H}), 4.12(\mathrm{bs}, 2 \mathrm{H}), 6.20(\mathrm{dd}, J=16.1$, $7.0 \mathrm{~Hz}, 1 \mathrm{H}), 6.53(\mathrm{~d}, J=16.1 \mathrm{~Hz}, 1 \mathrm{H}), 6.99$ (ddd, $J=10.8,8.1,1.2$ $\mathrm{Hz}, 1 \mathrm{H}), 7.05(\mathrm{dt}, J=7.6,1.2 \mathrm{~Hz}, 1 \mathrm{H}), 7.12-7.18(\mathrm{~m}, 1 \mathrm{H}), 7.41(\mathrm{dt}$, $J=7.7,1.8 \mathrm{~Hz}, 1 \mathrm{H})$. MS (ESI+): $m / z[\mathrm{M}+\mathrm{Na}]^{+} 328.17$; found 328.42 .

tert-Butyl 4-(2-Chloro-4-fluorostyryl)piperidine-1-carboxylate [Isomers (Z)-34 and (E)-35]. Synthesized from aldehyde 3 (1.50 g, $7.03 \mathrm{mmol}, 1.0$ equiv), $27 \mathrm{c}(3.76 \mathrm{~g}, 7.74 \mathrm{mmol}, 1.1$ equiv) and NaHMDS ( $2 \mathrm{~N}$ in THF, $4.22 \mathrm{~mL}, 8.44 \mathrm{mmol}, 1.2$ equiv) via general procedure $\mathrm{B}$. Column chromatography, petroleum ether/ $/ \mathrm{Et}_{2} \mathrm{O}$ $=10 / 1(\mathrm{v} / \mathrm{v})$. Overall yield of reaction: $52 \%$ (mass of both $Z$ and $E$ isomers, $1.24 \mathrm{~g}$ ); isolated pure $Z$ isomer, $114 \mathrm{mg}$; isolated pure $E$ isomer, $285 \mathrm{mg}$; mixture of $E / Z$ isomers, $0.841 \mathrm{~g}$.

34: $R_{f}=0.73($ EtOAc/n-hex $=1 / 2, \mathrm{v} / \mathrm{v})$; colorless oil. ${ }^{1} \mathrm{H}$ NMR $\left(400 \mathrm{MHz}, \mathrm{CDCl}_{3}\right): \delta 1.27(\mathrm{dt}, J=12.9,4.4 \mathrm{~Hz}, 1 \mathrm{H}), 1.30(\mathrm{dt}, J=$ $12.3,4.0 \mathrm{~Hz}, 1 \mathrm{H}), 1.39(\mathrm{~s}, 9 \mathrm{H}), 1.50-1.58(\mathrm{~m}, 2 \mathrm{H}), 2.60-2.40(\mathrm{~m}$, $1 \mathrm{H}), 2.60(\mathrm{t}, J=11.4 \mathrm{~Hz}, 2 \mathrm{H}), 4.01(\mathrm{bs}, 2 \mathrm{H}), 5.51(\mathrm{dd}, J=11.4,10.2$ $\mathrm{Hz}, 1 \mathrm{H}), 6.29(\mathrm{~d}, J=11.5 \mathrm{~Hz}, 1 \mathrm{H}), 6.89(\mathrm{dt}, J=8.5,3.0 \mathrm{~Hz}, 1 \mathrm{H})$, $7.06(\mathrm{dd}, J=8.5,2.6 \mathrm{~Hz}, 1 \mathrm{H}), 7.13(\mathrm{dd}, J=8.6,6.2 \mathrm{~Hz}, 1 \mathrm{H})$. MS (ESI $+): m / z[\mathrm{M}+\mathrm{K}]^{+}$378.10; found 378.66.

35: $R_{f}=0.68(\mathrm{EtOAc} / \mathrm{n}-\mathrm{hex}=1 / 2, \mathrm{v} / \mathrm{v})$; white crystals, mp 90-92 ${ }^{\circ} \mathrm{C} .{ }^{1} \mathrm{H}$ NMR $\left(400 \mathrm{MHz}, \mathrm{CDCl}_{3}\right): \delta 1.36(\mathrm{dt}, J=12.4,4.1 \mathrm{~Hz}, 1 \mathrm{H})$, $1.39(\mathrm{dt}, J=12.3,4.2 \mathrm{~Hz}, 1 \mathrm{H}), 1.46(\mathrm{~s}, 9 \mathrm{H}), 1.72-1.79(\mathrm{~m}, 2 \mathrm{H})$, $2.27-2.36(\mathrm{~m}, 1 \mathrm{H}), 2.77(\mathrm{t}, J=11.4 \mathrm{~Hz}, 2 \mathrm{H}), 4.13(\mathrm{bs}, 2 \mathrm{H}), 6.04$ $(\mathrm{dd}, J=15.9,6.9 \mathrm{~Hz}, 1 \mathrm{H}), 6.67(\mathrm{~d}, J=15.9 \mathrm{~Hz}, 1 \mathrm{H}), 6.92(\mathrm{dt}, J=8.4$, $2.6 \mathrm{~Hz}, 1 \mathrm{H}), 7.07(\mathrm{dd}, J=8.5,2.6 \mathrm{~Hz}, 1 \mathrm{H}), 7.44(\mathrm{dd}, J=8.8,6.1 \mathrm{~Hz}$, $1 \mathrm{H})$. MS (ESI+): $m / z[\mathrm{M}+\mathrm{Na}]^{+} 362.13$; found 362.40 .

tert-Butyl 4-(4-Methylstyryl)piperidine-1-carboxylate [Isomers (Z)-36 and $(E)-37$ ]. Synthesized from aldehyde $3(1.49 \mathrm{~g}, 7.00$ mmol, 1.0 equiv), $27 \mathrm{~d}$ ( $3.13 \mathrm{~g}, 7.00 \mathrm{mmol}, 1.0$ equiv), and KHMDS (0.5 $\mathrm{M}$ in toluene, $15.40 \mathrm{~mL}, 7.70 \mathrm{mmol}, 1.1$ equiv) via general procedure B. Column chromatography, EtOAc/n-hex $=1 / 5(\mathrm{v} / \mathrm{v})$. Overall yield of reaction: $45 \%$ (mass of both $Z$ and $E$ isomers, $0.94 \mathrm{~g}$ ); isolated pure $Z$ isomer, $159 \mathrm{mg}$; isolated pure $E$ isomer, $155 \mathrm{mg}$; mixture of $E / Z$ isomers, $0.626 \mathrm{~g}$.

36: $R_{f}=0.75(\mathrm{EtOAc} / \mathrm{n}$-hex $=1 / 5, \mathrm{v} / \mathrm{v})$; colorless oil. ${ }^{1} \mathrm{H}$ NMR $\left(400 \mathrm{MHz}, \mathrm{CDCl}_{3}\right): \delta 1.29-1.41(\mathrm{~m}, 2 \mathrm{H}), 1.46(\mathrm{~s}, 9 \mathrm{H}), 1.64-1.70$ $(\mathrm{m}, 2 \mathrm{H}), 2.35(\mathrm{~s}, 3 \mathrm{H}), 2.66-2.77(\mathrm{~m}, 3 \mathrm{H}), 4.08(\mathrm{bs}, 2 \mathrm{H}), 5.41(\mathrm{dd}, J$ $=11.6,10.0 \mathrm{~Hz}, 1 \mathrm{H}), 6.36(\mathrm{~d}, J=11.5 \mathrm{~Hz}, 1 \mathrm{H}), 7.12-7.17(\mathrm{~m}, 4 \mathrm{H})$. MS (ESI+): $m / z[\mathrm{M}+\mathrm{Na}]^{+}$324.19; found 324.63 .

37: $R_{f}=0.72(\mathrm{EtOAc} / \mathrm{n}-\mathrm{hex}=1 / 5, \mathrm{v} / \mathrm{v})$; colorless oil. ${ }^{1} \mathrm{H}$ NMR $\left(400 \mathrm{MHz}, \mathrm{CDCl}_{3}\right): \delta 1.36(\mathrm{dt}, J=12.2,4.2 \mathrm{~Hz}, 1 \mathrm{H}), 1.39(\mathrm{dt}, J=$ $12.4,4.3 \mathrm{~Hz}, 1 \mathrm{H}), 1.47(\mathrm{~s}, 9 \mathrm{H}), 1.71-1.78(\mathrm{~m}, 2 \mathrm{H}), 2.22-2.31(\mathrm{~m}$, $1 \mathrm{H}), 2.32(\mathrm{~s}, 3 \mathrm{H}), 2.77(\mathrm{t}, J=12,6 \mathrm{~Hz}, 2 \mathrm{H}), 4.12(\mathrm{bs}, 2 \mathrm{H}), 6.09(\mathrm{dd}, J$ $=16.0,6.9 \mathrm{~Hz}, 1 \mathrm{H}), 6.35(\mathrm{~d}, J=15.8 \mathrm{~Hz}, 1 \mathrm{H}), 7.09-7.12(\mathrm{~m}, 2 \mathrm{H})$, 7.22-7.25 (m, 2H). MS (ESI+): $m / z[\mathrm{M}+\mathrm{H}]^{+} 302.21$; found 302.60 .

tert-Butyl 4-(4-Isopropylstyryl)piperidine-1-carboxylate [Isomers (Z)-38 and (E)-39]. Synthesized from aldehyde 3 (1.30 g, $6.10 \mathrm{mmol}, 1.0$ equiv), $27 \mathrm{e}$ ( $3.19 \mathrm{~g}, 6.71 \mathrm{mmol}, 1.1$ equiv), and NaHMDS ( $2 \mathrm{~N}$ in THF, $3.66 \mathrm{~mL}, 7.32 \mathrm{mmol}, 1.2$ equiv) via general procedure $\mathrm{B}$. Column chromatography, petroleum ether $/ \mathrm{Et}_{2} \mathrm{O}=9 / 1$ (v/v). Overall yield of reaction: $65 \%$ (mass of both $Z$ and $E$ isomers, $1.78 \mathrm{~g}$ ); isolated pure $Z$ isomer, $194 \mathrm{mg}$; isolated pure $E$ isomer, 235 $\mathrm{mg}$; mixture of $E / Z$ isomers, $1.351 \mathrm{~g}$.

38: $R_{f}=0.31$ (petroleum ether $/ \mathrm{Et}_{2} \mathrm{O}=10 / 1, \mathrm{v} / \mathrm{v}$ ); colorless oil. ${ }^{1} \mathrm{H}$ $\operatorname{NMR}\left(400 \mathrm{MHz}, \mathrm{CDCl}_{3}\right): \delta 1.28(\mathrm{~d}, J=7.0 \mathrm{~Hz}, 6 \mathrm{H}), 1.36(\mathrm{dd}, J=$ $11.9,3.3 \mathrm{~Hz}, 1 \mathrm{H}), 1.39$ (dd, $J=11.8,3.0 \mathrm{~Hz}, 1 \mathrm{H}), 1.49$ (s, 9H), $1.68-$ $1.75(\mathrm{~m}, 2 \mathrm{H}), 2.72-2.81(\mathrm{~m}, 3 \mathrm{H}), 2.92(\mathrm{sept}, J=6.9 \mathrm{~Hz}, 1 \mathrm{H}), 4.11$ (bs, $2 \mathrm{H}), 5.42(\mathrm{dd} J=11.7,10.0 \mathrm{~Hz}, 1 \mathrm{H}), 6.36(\mathrm{~d}, J=11.7 \mathrm{~Hz}, 1 \mathrm{H})$, 7.18-7.23 (m, 4H). MS (ESI+): $m / z[\mathrm{M}+\mathrm{Na}]^{+} 352.22$; found 352.00 .

39: $R_{f}=0.24$ (petroleum ether $/ \mathrm{Et}_{2} \mathrm{O}=10 / 1, \mathrm{v} / \mathrm{v}$ ); colorless oil. ${ }^{1} \mathrm{H}$ $\operatorname{NMR}\left(400 \mathrm{MHz}, \mathrm{CDCl}_{3}\right): \delta 1.25(\mathrm{~d}, J=7.0 \mathrm{~Hz}, 6 \mathrm{H}), 1.37(\mathrm{dd}, J=$ $12.8,4.1 \mathrm{~Hz}, 1 \mathrm{H}), 1.40(\mathrm{dd}, J=12.1,3.9 \mathrm{~Hz}, 1 \mathrm{H}), 1.49(\mathrm{~s}, 9 \mathrm{H}), 1.71-$ $1.79(\mathrm{~m}, 2 \mathrm{H}), 2.22-2.30(\mathrm{~m}, 1 \mathrm{H}), 2.78(\mathrm{t}, J=11.4 \mathrm{~Hz}, 2 \mathrm{H}), 2.89$ (sept, $J=7.0 \mathrm{~Hz}, 1 \mathrm{H}), 4.14$ (bs, $2 \mathrm{H}), 6.11$ (dd, $J=16.0,6.9 \mathrm{~Hz}, 1 \mathrm{H})$, $6.38(\mathrm{~d}, J=15.9 \mathrm{~Hz}, 1 \mathrm{H}), 7.16-7.18(\mathrm{~m}, 2 \mathrm{H}), 7.28-7.30(\mathrm{~m}, 2 \mathrm{H})$. MS (ESI+): $m / z[\mathrm{M}+\mathrm{Na}]^{+}$352.22; found 352.01.

tert-Butyl 4-(4-Chlorostyryl)piperidine-1-carboxylate [Isomers $(Z)-40$ and $(E)-41]$. Synthesized from aldehyde 3 (2.00 g, $9.38 \mathrm{mmol}, 1.0$ equiv), $27 \mathrm{f}(4.37 \mathrm{~g}, 10.32 \mathrm{mmol}, 1.1 \mathrm{equiv})$, and NaHMDS ( $2 \mathrm{~N}$ in THF, $5.63 \mathrm{~mL}, 11.26 \mathrm{mmol}, 1.2$ equiv) via general procedure $\mathrm{B}$. Column chromatography, petroleum ether $/ \mathrm{Et}_{2} \mathrm{O}=10 / 1$ (v/v). Overall yield of reaction: $63 \%$ (mass of both $Z$ and $E$ isomers, $1.78 \mathrm{~g}$ ); isolated pure $Z$ isomer, $202 \mathrm{mg}$; isolated pure $E$ isomer, 221 $\mathrm{mg}$; mixture of $E / Z$ isomers, $1.357 \mathrm{~g}$.

40: $R_{f}=0.15$ (petroleum ether $/ \mathrm{Et}_{2} \mathrm{O}=10 / 1, \mathrm{v} / \mathrm{v}$ ); white crystals, $\mathrm{mp} 69-70{ }^{\circ} \mathrm{C} .{ }^{1} \mathrm{H}$ NMR $\left(400 \mathrm{MHz}, \mathrm{CDCl}_{3}\right): \delta 1.38$ (ddd, $J=17.4$, $13.3,4.7 \mathrm{~Hz}, 2 \mathrm{H}), 1.46(\mathrm{~s}, 9 \mathrm{H}), 1.61-1.67(\mathrm{~m}, 2 \mathrm{H}), 2.58-2.76(\mathrm{~m}$, $3 \mathrm{H}), 4.08(\mathrm{bs}, 2 \mathrm{H}), 5.47(\mathrm{dd}, J=11.6,10.1 \mathrm{~Hz}, 1 \mathrm{H}), 6.36(\mathrm{~d}, J=11.7$ $\mathrm{Hz}, 1 \mathrm{H}), 7.14-7.17(\mathrm{~m}, 2 \mathrm{H}), 7.28-7.32(\mathrm{~m}, 2 \mathrm{H}) . \mathrm{MS}(\mathrm{ESI}+): \mathrm{m} / z$ $[\mathrm{M}+\mathrm{Na}]^{+}$344.14; found 344.54.

41: $R_{f}=0.10$ (petroleum ether $/ \mathrm{Et}_{2} \mathrm{O}=10 / 1, \mathrm{v} / \mathrm{v}$ ); white crystals, mp 60-62 ${ }^{\circ} \mathrm{C} .{ }^{1} \mathrm{H}$ NMR $\left(400 \mathrm{MHz}, \mathrm{CDCl}_{3}\right): \delta 1.35$ (dd, $J=12.4,4.1$ $\mathrm{Hz}, 1 \mathrm{H}), 1.38(\mathrm{dd}, J=12.2,4.1 \mathrm{~Hz}, 1 \mathrm{H}), 1.46(\mathrm{~s}, 9 \mathrm{H}), 1.71-1.77(\mathrm{~m}$, $2 \mathrm{H}), 2.22-2.31(\mathrm{~m}, 1 \mathrm{H}), 2.77(\mathrm{t}, J=11.5 \mathrm{~Hz}, 2 \mathrm{H}), 4.14(\mathrm{bs}, 2 \mathrm{H})$, $6.11(\mathrm{dd}, J=16.0,6.9 \mathrm{~Hz}, 1 \mathrm{H}), 6.32(\mathrm{dd}, J=16.0,1.2 \mathrm{~Hz}, 1 \mathrm{H}), 7.52$ (s, 4H). MS (ESI+): $m / z[\mathrm{M}+\mathrm{Na}]^{+} 344.14$; found 344.48.

tert-Butyl 4-(4-Bromostyryl)piperidine-1-carboxylate [Isomers $(Z)-42$ and $(E)-43]$. Synthesized from aldehyde $3(2.00 \mathrm{~g}$, $9.38 \mathrm{mmol}, 1.0$ equiv), $27 \mathrm{~g}$ (5.28 g, $10.31 \mathrm{mmol}, 1.1$ equiv), and NaHMDS ( $2 \mathrm{~N}$ in THF, $5.63 \mathrm{~mL}, 11.26 \mathrm{mmol}, 1.2$ equiv) via general procedure B. Column chromatography, EtOAc/n-hex $=1 / 2(\mathrm{v} / \mathrm{v})$. Overall yield of reaction: $48 \%$ (mass of both $Z$ and $E$ isomers, $1.66 \mathrm{~g}$ ); pure $Z$ isomer was not isolated; isolated pure $E$ isomer, $325 \mathrm{mg}$; mixture of $E / Z$ isomers, $1.335 \mathrm{~g}$.

43: $R_{f}=0.40($ EtOAc/n-hex $=1 / 2, \mathrm{v} / \mathrm{v})$; white crystals, $\mathrm{mp}$ 65-67 ${ }^{\circ} \mathrm{C} .{ }^{1} \mathrm{H}$ NMR $\left(400 \mathrm{MHz}, \mathrm{CDCl}_{3}\right): \delta 1.36(\mathrm{dt}, J=12.4,4.2 \mathrm{~Hz}, 1 \mathrm{H})$, 
$1.39(\mathrm{dt}, J=12.4,4.5 \mathrm{~Hz}, 1 \mathrm{H}), 1.47(\mathrm{~s}, 9 \mathrm{H}), 1.71-1.78(\mathrm{~m}, 2 \mathrm{H})$, $2.22-2.32(\mathrm{~m}, 1 \mathrm{H}), 2.74-2.81(\mathrm{~m}, 2 \mathrm{H}), 4.12(\mathrm{bs}, 2 \mathrm{H}), 6.13(\mathrm{dd}, J=$ $16.0,6.8 \mathrm{~Hz}, 1 \mathrm{H}), 6.32(\mathrm{~d}, J=16.0 \mathrm{~Hz}, 1 \mathrm{H}), 7.19-7.22(\mathrm{~m}, 2 \mathrm{H})$, $7.39-7.43(\mathrm{~m}, 2 \mathrm{H})$.

tert-Butyl 4-(4-Methoxystyryl)piperidine-1-carboxylate [Isomers $(Z)-44$ and $(E)-45]$. Synthesized from aldehyde 3 (1.87 g, 8.77 mmol, 1.0 equiv), $27 \mathrm{~h}$ ( $4.04 \mathrm{~g}, 9.65 \mathrm{mmol}, 1.1$ equiv), and NaHMDS ( $2 \mathrm{~N}$ in THF, $5.26 \mathrm{~mL}, 10.52 \mathrm{mmol}, 1.2$ equiv) via general procedure B. Column chromatography, EtOAc/n-hex $=1 / 9(\mathrm{v} / \mathrm{v})$ yielding a mixture of cis/trans isomers (ratio 20/80, estimated from ${ }^{1} \mathrm{H}$ NMR). Overall yield of reaction: $40 \%$ (mass of both $Z$ and $E$ isomers, $1.12 \mathrm{~g}$ ); pure $Z$ and $E$ isomers were not isolated.

44 and 45 (mixture of both isomers): $R_{f}=0.13$ (EtOAc/n-hex $=1$ / 9, v/v); colorless oil. ${ }^{1} \mathrm{H}$ NMR (400 MHz, $\left.\mathrm{CDCl}_{3}\right): \delta 1.31-1.41(\mathrm{~m}$, $2.6 \mathrm{H}), 1.46-1.47(\mathrm{~m}, 11.5 \mathrm{H}), 1.63-1.75(\mathrm{~m}, 2.6 \mathrm{H}), 2.20-2.29(\mathrm{~m}$, $1 \mathrm{H}), 2.69-2.82(\mathrm{~m}, 2.6 \mathrm{H}), 3.78(\mathrm{~s}, 3 \mathrm{H}), 3.78(\mathrm{~s}, 0.7 \mathrm{H}), 4.12(\mathrm{bs}$, $2.6 \mathrm{H}), 5.36(\mathrm{dd}, J=11.6,10.0 \mathrm{~Hz}, 0.2 \mathrm{H}), 5.99(\mathrm{dd}, J=16.0,6.9 \mathrm{~Hz}$, $1 \mathrm{H}), 6.30-6.34(\mathrm{~m}, 1.2 \mathrm{H}), 6.81-6.85(\mathrm{~m}, 2 \mathrm{H}), 6.85-6.89(\mathrm{~m}$, $0.5 \mathrm{H}), 7.16-7.19(\mathrm{~m}, 0.5 \mathrm{H}), 7.24-7.29(\mathrm{~m}, 2 \mathrm{H})$. MS (ESI+): $\mathrm{m} / \mathrm{z}$ $[\mathrm{M}+\mathrm{Na}]^{+} 340.19$; found 340.04 .

tert-Butyl 4-(4-(Trifluoromethyl)styryl)piperidine-1-carboxylate [Isomers (Z)-46 and (E)-47]. Synthesized from aldehyde 3 ( $2.00 \mathrm{~g}, 9.38 \mathrm{mmol}, 1.0$ equiv), $27 \mathrm{i}(5.56 \mathrm{~g}, 10.32 \mathrm{mmol}, 1.1$ equiv), and NaHMDS ( $2 \mathrm{~N}$ in THF, $5.63 \mathrm{~mL}, 11.26 \mathrm{mmol}, 1.2$ equiv) via general procedure $\mathrm{B}$. Column chromatography, petroleum ether/ $\mathrm{Et}_{2} \mathrm{O}$ $=9 / 1(\mathrm{v} / \mathrm{v})$. Overall yield of reaction: $66 \%$ (mass of both $Z$ and $E$ isomers, $2.18 \mathrm{~g}$ ); isolated pure $Z$ isomer, $85 \mathrm{mg}$; isolated pure $E$ isomer, $780 \mathrm{mg}$; mixture of $E / Z$ isomers, $1.305 \mathrm{~g}$.

46: $R_{f}=0.23$ (petroleum ether $/ \mathrm{Et}_{2} \mathrm{O}=9 / 1, \mathrm{v} / \mathrm{v}$ ); colorless oil. ${ }^{1} \mathrm{H}$ NMR $\left(400 \mathrm{MHz}, \mathrm{CDCl}_{3}\right): \delta 1.32-1.42(\mathrm{~m}, 2 \mathrm{H}), 1.45(\mathrm{~s}, 9 \mathrm{H}), 1.62-$ $1.67(\mathrm{~m}, 2 \mathrm{H}), 2.59-2.68(\mathrm{~m}, 1 \mathrm{H}), 2.71(\mathrm{t}, J=12.8 \mathrm{~Hz}, 2 \mathrm{H}), 4.09(\mathrm{bs}$, $2 \mathrm{H}), 5.56(\mathrm{dd}, J=11.7,10.2 \mathrm{~Hz}, 1 \mathrm{H}), 6.36(\mathrm{~d}, J=11.7 \mathrm{~Hz}, 1 \mathrm{H}), 7.32$ $(\mathrm{d}, J=8.5 \mathrm{~Hz}, 2 \mathrm{H}), 7.58(\mathrm{~d}, J=8.1 \mathrm{~Hz}, 2 \mathrm{H})$.

47: $R_{f}=0.18$ (petroleum ether $/ \mathrm{Et}_{2} \mathrm{O}=9 / 1, \mathrm{v} / \mathrm{v}$ ); white crystals, mp 46-48 ${ }^{\circ} \mathrm{C} .{ }^{1} \mathrm{H}$ NMR $\left(400 \mathrm{MHz}, \mathrm{CDCl}_{3}\right): \delta 1.35$ (dd, $J=12.2,4.1$ $\mathrm{Hz}, 1 \mathrm{H}), 1.39$ (dd, $J=12.5,4.1 \mathrm{~Hz}, 1 \mathrm{H}), 1.46(\mathrm{~s}, 9 \mathrm{H}), 1.71-1.77(\mathrm{~m}$, $2 \mathrm{H}), 2.24-2.33(\mathrm{~m}, 1 \mathrm{H}), 2.76(\mathrm{t}, J=11.4 \mathrm{~Hz}, 2 \mathrm{H}), 4.14(\mathrm{bs}, 2 \mathrm{H})$, $6.22(\mathrm{dd}, J=16.0,6.8 \mathrm{~Hz}, 1 \mathrm{H}), 6.38(\mathrm{~d}, J=16.1 \mathrm{~Hz}, 1 \mathrm{H}), 7.40(\mathrm{~d}, J=$ $8.4 \mathrm{~Hz}, 2 \mathrm{H}), 7.51(\mathrm{~d}, J=8.2 \mathrm{~Hz}, 2 \mathrm{H})$.

tert-Butyl 4-(3-(Trifluoromethyl)styryl)piperidine-1-carboxylate [Isomers (Z)-48 and (E)-49]. Synthesized from aldehyde 3 ( $1.49 \mathrm{~g}, 7.00 \mathrm{mmol}, 1.0$ equiv), $27 \mathrm{j}(3.51 \mathrm{~g}, 7.00 \mathrm{mmol}, 1.0$ equiv), and KHMDS ( $0.5 \mathrm{M}$ in toluene, $15.40 \mathrm{~mL}, 7.70 \mathrm{mmol}, 1.1$ equiv) via general procedure $\mathrm{B}$. Column chromatography, petroleum ether/ $/ \mathrm{Et}_{2} \mathrm{O}$ $=8 / 1,(\mathrm{v} / \mathrm{v})$. Overall yield of reaction: $62 \%$ (mass of both $Z$ and $E$ isomers, $1.53 \mathrm{~g}$ ); isolated pure $Z$ isomer, $51 \mathrm{mg}$; isolated pure $E$ isomer, $404 \mathrm{mg}$; mixture of $E / Z$ isomers, $1.075 \mathrm{~g}$.

48: $R_{f}=0.20$ (petroleum ether $/ \mathrm{Et}_{2} \mathrm{O}=8 / 1, \mathrm{v} / \mathrm{v}$ ), colorless oil. ${ }^{1} \mathrm{H}$ NMR $\left(400 \mathrm{MHz}, \mathrm{CDCl}_{3}\right): \delta: 1.35(\mathrm{dt}, J=12.6,4.0 \mathrm{~Hz}, 1 \mathrm{H}), 1.36-$ $1.43(\mathrm{~m}, 1 \mathrm{H}), 1.45(\mathrm{~s}, 9 \mathrm{H}), 1.61-1.68(\mathrm{~m}, 2 \mathrm{H}), 2.56-2.66(\mathrm{~m}, 1 \mathrm{H})$, $2.71(\mathrm{t}, J=11.2 \mathrm{~Hz}, 2 \mathrm{H}), 4.08(\mathrm{bs}, 2 \mathrm{H}), 5.55(\mathrm{dd}, J=11.6,10.2 \mathrm{~Hz}$, $1 \mathrm{H}), 6.40(\mathrm{~d}, J=11.6 \mathrm{~Hz}, 1 \mathrm{H}), 7.38-7.50(\mathrm{~m}, 4 \mathrm{H})$. MS (ESI+): $\mathrm{m} / z$ $[\mathrm{M}+\mathrm{Na}]^{+} 378.17$; found 378.76 .

49: $R_{\mathrm{f}}=0.15$ (petroleum ether $/ \mathrm{Et}_{2} \mathrm{O}=8 / 1, \mathrm{v} / \mathrm{v}$ ); colorless oil. ${ }^{1} \mathrm{H}$ NMR (400 MHz, CDCl $): \delta 1.37(\mathrm{dt}, J=12.4,4.3 \mathrm{~Hz}, 1 \mathrm{H}), 1.40(\mathrm{dt}$, $J=12.2,4.1 \mathrm{~Hz}, 1 \mathrm{H}), 1.47(\mathrm{~s}, 9 \mathrm{H}), 1.73-1.80(\mathrm{~m}, 2 \mathrm{H}), 2.26-2.36$ $(\mathrm{m}, 1 \mathrm{H}), 2.78(\mathrm{t}, J=12.0 \mathrm{~Hz}, 2 \mathrm{H}), 4.14(\mathrm{bs}, 2 \mathrm{H}), 6.22(\mathrm{dd}, J=16.0$, $6.9 \mathrm{~Hz}, 1 \mathrm{H}), 6.41(\mathrm{~d}, J=16.0 \mathrm{~Hz}, 1 \mathrm{H}), 7.38-7.46(\mathrm{~m}, 2 \mathrm{H}), 7.48-$ $7.51(\mathrm{~m}, 1 \mathrm{H}), 7.57-7.59(\mathrm{~m}, 1 \mathrm{H}) . \mathrm{MS}(\mathrm{ESI}+): m / z[\mathrm{M}+\mathrm{Na}]^{+}$ 378.17; found 378.69 .

tert-Butyl 4-(4-Cyanostyryl)piperidine-1-carboxylate [Isomers $(Z)-50$ and $(E)-51]$. Synthesized from aldehyde $3(2.35 \mathrm{~g}$, $11.02 \mathrm{mmol}, 1.0$ equiv), 27k (5.56 g, $12.12 \mathrm{mmol}, 1.1$ equiv), and NaHMDS ( $2 \mathrm{~N}$ in THF, $6.61 \mathrm{~mL}, 13.22 \mathrm{mmol}, 1.2$ equiv) via general procedure $\mathrm{B}$. Column chromatography, petroleum ether $/ \mathrm{Et}_{2} \mathrm{O}=3 / 1$ (v/v). Overall yield of reaction: $39 \%$ (mass of both $Z$ and $E$ isomers, $1.35 \mathrm{~g}$ ); isolated pure $Z$ isomer, $370 \mathrm{mg}$; isolated pure $E$ isomer, 320 $\mathrm{mg}$; mixture of $E / Z$ isomers, $0.66 \mathrm{~g}$.

50: $R_{f}=0.20$ (petroleum ether $/ \mathrm{Et}_{2} \mathrm{O}=3 / 1, \mathrm{v} / \mathrm{v}$ ); white crystals, mp $65-68{ }^{\circ} \mathrm{C} .{ }^{1} \mathrm{H}$ NMR $\left(400 \mathrm{MHz}, \mathrm{CDCl}_{3}\right): \delta 1.31-1.40(\mathrm{~m}, 2 \mathrm{H})$, $1.43(\mathrm{~s}, 9 \mathrm{H}), 1.57-1.64(\mathrm{~m}, 2 \mathrm{H}), 2.54-2.64(\mathrm{~m}, 1 \mathrm{H}), 2.70(\mathrm{t}, J=$ $11.7 \mathrm{~Hz}, 2 \mathrm{H}), 4.05(\mathrm{bs}, 2 \mathrm{H}), 5.58(\mathrm{dd}, J=11.7,10.2 \mathrm{~Hz}, 1 \mathrm{H}), 6.36$ $(\mathrm{d}, J=11.8 \mathrm{~Hz}, 1 \mathrm{H}), 7.28-7.31(\mathrm{~m}, 2 \mathrm{H}), 7.58-7.61(\mathrm{~m}, 2 \mathrm{H}) . \mathrm{MS}$ (ESI+): $m / z[\mathrm{M}+\mathrm{Na}]^{+} 335.17$; found 335.31 .

51: $R_{f}=0.14$ (petroleum ether $/ \mathrm{Et}_{2} \mathrm{O}=3 / 1, \mathrm{v} / \mathrm{v}$ ); white crystals, $\mathrm{mp} 88-90{ }^{\circ} \mathrm{C} .{ }^{1} \mathrm{H}$ NMR $\left(400 \mathrm{MHz}, \mathrm{CDCl}_{3}\right): \delta 1.30-1.40(\mathrm{~m}, 2 \mathrm{H})$, $1.43(\mathrm{~s}, 9 \mathrm{H}), 1.70-1.75(\mathrm{~m}, 2 \mathrm{H}), 2.25-2.34(\mathrm{~m}, 1 \mathrm{H}), 2.75(\mathrm{t}, J=$ $10.7 \mathrm{~Hz}, 2 \mathrm{H}), 4.11(\mathrm{bs}, 2 \mathrm{H}), 6.26(\mathrm{dd}, J=16.0,6.6 \mathrm{~Hz}, 1 \mathrm{H}), 6.36(\mathrm{~d}$, $J=16.0 \mathrm{~Hz}, 1 \mathrm{H}), 7.37-7.39(\mathrm{~m}, 2 \mathrm{H}), 7.52-7.55(\mathrm{~m}, 2 \mathrm{H})$. MS (ESI $+): m / z[\mathrm{M}-\mathrm{H}]^{-}$311.17; found 311.37 .

tert-Butyl 4-(4-(Methylsulfonyl)styryl)piperidine-1-carboxylate [lsomers (Z)-52 and (E)-53]. Synthesized from aldehyde 3 (0.94 g, $4.10 \mathrm{mmol}, 1.0$ equiv), 271 (1.94 g, $4.50 \mathrm{mmol}, 1.1$ equiv), and NaHMDS ( $2 \mathrm{~N}$ in THF, $2.45 \mathrm{~mL}, 4.90 \mathrm{mmol}, 1.2$ equiv) via general procedure B. Column chromatography, EtOAc/n-hex $=1 / 2$ (v/v). Overall yield of reaction: $30 \%$ (mass of both $Z$ and $E$ isomers, $0.46 \mathrm{~g}$ ); isolated pure $Z$ isomer, $180 \mathrm{mg}$; isolated pure $E$ isomer, 260 $\mathrm{mg}$; mixture of $E / Z$ isomers, $0.02 \mathrm{~g}$.

52: $R_{f}=0.27($ EtOAc $/ \mathrm{n}-\mathrm{hex}=1 / 2, \mathrm{v} / \mathrm{v})$; colorless oil. ${ }^{1} \mathrm{H}$ NMR $\left(400 \mathrm{MHz}, \mathrm{CDCl}_{3}\right): \delta 1.34-1.45(\mathrm{~m}, 2 \mathrm{H}), 1.47(\mathrm{~s}, 9 \mathrm{H}), 1.62-1.69$ $(\mathrm{m}, 2 \mathrm{H}), 2.58-2.68(\mathrm{~m}, 1 \mathrm{H}), 2.72(\mathrm{t}, J=12.0 \mathrm{~Hz}, 2 \mathrm{H}), 3.08(\mathrm{~s}, 3 \mathrm{H})$, 4.11 (bs, $2 \mathrm{H}), 5.62(\mathrm{dd}, J=11.6,10.4 \mathrm{~Hz}, 1 \mathrm{H}), 6.44(\mathrm{~d}, J=11.6 \mathrm{~Hz}$, $1 \mathrm{H}), 7.40-7.43(\mathrm{~m}, 2 \mathrm{H}), 7.90-7.93(\mathrm{~m}, 2 \mathrm{H})$. MS (ESI +$): m / z[\mathrm{M}+$ $\mathrm{Na}]^{+}$388.16; found 387.91 .

53: $R_{f}=0.22($ EtOAc/n-hex $=1 / 2, \mathrm{v} / \mathrm{v})$; white crystals, mp 93-97 ${ }^{\circ} \mathrm{C} .{ }^{1} \mathrm{H}$ NMR $\left(400 \mathrm{MHz}, \mathrm{CDCl}_{3}\right): \delta 1.38(\mathrm{dt}, J=12.4,4.1 \mathrm{~Hz}, 1 \mathrm{H})$, $1.41(\mathrm{dd}, J=12.4,4.0 \mathrm{~Hz}, 1 \mathrm{H}), 1.47(\mathrm{~s}, 9 \mathrm{H}), 1.75-1.83(\mathrm{~m}, 2 \mathrm{H})$, $2.30-2.39(\mathrm{~m}, 1 \mathrm{H}), 2.79(\mathrm{t}, J=10.7 \mathrm{~Hz}, 2 \mathrm{H}), 3.05(\mathrm{~s}, 3 \mathrm{H}), 4.15(\mathrm{bs}$, $2 \mathrm{H}), 6.33(\mathrm{dd}, J=16.0,6.7 \mathrm{~Hz}, 1 \mathrm{H}), 6.45(\mathrm{~d}, J=16.0 \mathrm{~Hz}, 1 \mathrm{H}), 7.50-$ $7.53(\mathrm{~m}, 2 \mathrm{H}), 7.85-7.88(\mathrm{~m}, 2 \mathrm{H}) . \mathrm{MS}(\mathrm{ESI}+): m / z[\mathrm{M}+\mathrm{Na}]^{+}$ 388.16; found 387.91.

tert-Butyl 4-(4-Cyclopropylstyryl)piperidine-1-carboxylate [Isomers (Z)-54 and (E)-55]. To the solution of $\mathbf{4 2}$ and 43 (0.733 $\mathrm{g}, 2.0 \mathrm{mmol}, 1.0$ equiv), cyclopropylboronic acid $(0.224 \mathrm{~g}, 2.60 \mathrm{mmol}$, 1.3 equiv), $\mathrm{K}_{3} \mathrm{PO}_{4}(1.48 \mathrm{~g}, 7.00 \mathrm{mmol}, 3.5$ equiv) and tricyclohexylphosphine $(20 \%$ solution in toluene, $0.316 \mathrm{~mL}, 0.20 \mathrm{mmol}, 0.1$ equiv) in toluene $(10 \mathrm{~mL})$ and water $(0.4 \mathrm{~mL}), \mathrm{Pd}(\mathrm{OAc})_{2}(23 \mathrm{mg}$, $0.1 \mathrm{mmol}, 0.05$ equiv) was added under an argon atmosphere. The reaction mixture was stirred at $100{ }^{\circ} \mathrm{C}$ for $3 \mathrm{~h}$ and then allowed to cool down to room temperature. Water $(20 \mathrm{~mL})$ was added to the mixture, which was then transferred into a separating funnel, and extracted with EtOAc $(2 \times 50 \mathrm{~mL})$. Combined organic layers were washed with saturated brine $(20 \mathrm{~mL})$, dried over $\mathrm{Na}_{2} \mathrm{SO}_{4}$, and evaporated. Column chromatography, petroleum ether $/ \mathrm{Et}_{2} \mathrm{O}=10 / 1$ (v/v). Overall yield of reaction: $78 \%$ (mass of both $Z$ and $E$ isomers, $0.511 \mathrm{~g}$ ); isolated pure $Z$ isomer, $85 \mathrm{mg}$; isolated pure $E$ isomer, 210 $\mathrm{mg}$; mixture of $E / Z$ isomers, $0.216 \mathrm{~g}$.

54: $R_{f}=0.29$ (petroleum ether $/ \mathrm{Et}_{2} \mathrm{O}=10 / 1, \mathrm{v} / \mathrm{v}$ ); colorless oil. ${ }^{1} \mathrm{H}$ NMR (400 MHz, $\left.\mathrm{CDCl}_{3}\right): \delta 0.68-0.73(\mathrm{~m}, 2 \mathrm{H}), 0.94-1.00(\mathrm{~m}, 2 \mathrm{H})$, $1.30-1.41(\mathrm{~m}, 2 \mathrm{H}), 1.47(\mathrm{~s}, 9 \mathrm{H}), 1.63-1.70(\mathrm{~m}, 2 \mathrm{H}), 1.86-1.93(\mathrm{~m}$, $1 \mathrm{H}), 2.67-2.79(\mathrm{~m}, 3 \mathrm{H}), 4.09$ (bs, $2 \mathrm{H}), 5.40(\mathrm{dd}, J=11.6,10.0 \mathrm{~Hz}$, $1 \mathrm{H}), 6.35(\mathrm{~d}, J=11.6 \mathrm{~Hz}, 1 \mathrm{H}), 7.03-7.06(\mathrm{~m}, 2 \mathrm{H}), 7.12-7.16(\mathrm{~m}$, 2H)

55: $R_{f}=0.22$ (petroleum ether $/ \mathrm{Et}_{2} \mathrm{O}=10 / 1, \mathrm{v} / \mathrm{v}$ ); colorless oil. ${ }^{1} \mathrm{H}$ $\operatorname{NMR}\left(400 \mathrm{MHz}, \mathrm{CDCl}_{3}\right): \delta 0.66-0.70(\mathrm{~m}, 2 \mathrm{H}), 0.92-0.97(\mathrm{~m}, 2 \mathrm{H})$ $1.36(\mathrm{dt}, J=12.7,4.4 \mathrm{~Hz}, 1 \mathrm{H}), 1.39(\mathrm{dt}, J=12.3,4.1 \mathrm{~Hz}, 1 \mathrm{H}), 1.48(\mathrm{~s}$, $9 \mathrm{H}), 1.70-1.78(\mathrm{~m}, 2 \mathrm{H}), 1.83-1.90(\mathrm{~m}, 1 \mathrm{H}), 2.21-2.31(\mathrm{~m}, 1 \mathrm{H})$, $2.78(\mathrm{t}, J=11.6 \mathrm{~Hz}, 2 \mathrm{H}), 4.13(\mathrm{bs}, 2 \mathrm{H}), 6.08(\mathrm{dd}, J=16.0,6.9 \mathrm{~Hz}$, $1 \mathrm{H}), 6.34(\mathrm{~d}, J=16.0 \mathrm{~Hz}, 1 \mathrm{H}), 6.98-7.02(\mathrm{~m}, 2 \mathrm{H}), 7.22-7.25(\mathrm{~m}$, $2 \mathrm{H})$.

tert-Butyl 4-Phenethylpiperidine-1-carboxylate (56). Synthesized from a mixture of $\mathbf{2 8}$ and 29 (1.139 g, $4.84 \mathrm{mmol}, 1.0$ equiv) via general procedure C. Yield: quantitative $(1.39 \mathrm{~g})$; colorless oil. ${ }^{1} \mathrm{H}$ NMR $\left(400 \mathrm{MHz}, \mathrm{CDCl}_{3}\right): \delta 1.21$ (ddd, $J=16.5,12.5,4.3 \mathrm{~Hz}, 2 \mathrm{H}$ ), $1.35-1.43(\mathrm{~m}, 1 \mathrm{H}), 1.45(\mathrm{~s}, 9 \mathrm{H}), 1.53-1.59(\mathrm{~m}, 2 \mathrm{H}), 1.68-1.71(\mathrm{~m}$, $2 \mathrm{H}), 2.60-2.69(\mathrm{~m}, 4 \mathrm{H}), 4.07(\mathrm{bs}, 2 \mathrm{H}), 7.15-7.19(\mathrm{~m}, 3 \mathrm{H}), 7.24-$ $7.29(\mathrm{~m}, 2 \mathrm{H})$. MS (ESI+): $m / z[\mathrm{M}+\mathrm{Na}]^{+} 312.19$; found 311.91 .

tert-Butyl 4-(3-Fluorophenethyl)piperidine-1-carboxylate (57). Synthesized from a mixture of $\mathbf{3 0}$ and $31(0.452 \mathrm{~g}, 1.48$ mmol, 1.0 equiv) via general procedure C. Yield: $95 \%$ (0.432 g); pale 
yellow oil. ${ }^{1} \mathrm{H}$ NMR $\left(400 \mathrm{MHz}, \mathrm{CDCl}_{3}\right): \delta 1.11(\mathrm{dt}, J=12.3,4.1 \mathrm{~Hz}$, $1 \mathrm{H}), 1.14(\mathrm{dt}, J=12.5,4.2 \mathrm{~Hz}, 1 \mathrm{H}), 1.35-1.44(\mathrm{~m}, 1 \mathrm{H}), 1.45(\mathrm{~s}$, $9 \mathrm{H}), 1.50-1.59(\mathrm{~m}, 2 \mathrm{H}), 1.65-1.72(\mathrm{~m}, 2 \mathrm{H}), 2.59-2.72(\mathrm{~m}, 4 \mathrm{H})$, $4.08(\mathrm{bs}, 2 \mathrm{H}), 6.84-6.89(\mathrm{~m}, 2 \mathrm{H}), 6.91-6.95(\mathrm{~m}, 1 \mathrm{H}), 7.22(\mathrm{ddd}, J=$ 8.9, 7.6, $6.1 \mathrm{~Hz}, 1 \mathrm{H})$. MS (ESI+): $m / z[\mathrm{M}+\mathrm{Na}]^{+} 330.18$; found 330.42 .

tert-Butyl 4-(2-Fluorophenethyl)piperidine-1-carboxylate (58). Synthesized from a mixture of 32 and $33(0.252 \mathrm{~g}, 0.83$ mmol, 1.0 equiv) via general procedure C. Yield: $95 \%$ ( $0.242 \mathrm{~g})$; pale yellow oil. ${ }^{1} \mathrm{H}$ NMR $\left(400 \mathrm{MHz}, \mathrm{CDCl}_{3}\right): \delta 1.12(\mathrm{dt}, J=12.4,4.1 \mathrm{~Hz}$, $1 \mathrm{H}), 1.15(\mathrm{dt}, J=12.4,4.2 \mathrm{~Hz}, 1 \mathrm{H}), 1.37-1.44(\mathrm{~m}, 1 \mathrm{H}), 1.46(\mathrm{~s}$, $9 \mathrm{H}), 1.52-1.59(\mathrm{~m}, 2 \mathrm{H}), 1.69-1.76(\mathrm{~m}, 2 \mathrm{H}), 2.58-2.72(\mathrm{~m}, 4 \mathrm{H})$, 4.08 (bs, $2 \mathrm{H}), 6.97-7.02(\mathrm{~m}, 1 \mathrm{H}), 7.03-7.04(\mathrm{~m}, 1 \mathrm{H}), 7.13-7.19$ (m, 2H). MS (ESI+): $m / z[\mathrm{M}+\mathrm{Na}]^{+} 330.18$; found 330.41.

tert-Butyl 4-(4-Methylphenethyl)piperidine-1-carboxylate (59). Synthesized from a mixture of 36 and $37(0.28 \mathrm{~g}, 0.93 \mathrm{mmol}$, 1.0 equiv) via general procedure C. Yield: quantitative; yellow oil. ${ }^{1} \mathrm{H}$ NMR (400 MHz, CDCl $): \delta 1.11(\mathrm{dt}, J=12.3,4.1 \mathrm{~Hz}, 1 \mathrm{H}), 1.14(\mathrm{dt}$, $J=12.4,4.1 \mathrm{~Hz}, 1 \mathrm{H}), 1.36-1.44(\mathrm{~m}, 1 \mathrm{H}), 1.45(\mathrm{~s}, 9 \mathrm{H}), 1.51-1.57$ $(\mathrm{m}, 2 \mathrm{H}), 1.65-1.73(\mathrm{~m}, 2 \mathrm{H}), 2.32(\mathrm{~s}, 3 \mathrm{H}), 2.56-2.61(\mathrm{~m}, 2 \mathrm{H})$, 2.63-2.70 (m, 2H), 4.07 (bs, $2 \mathrm{H}), 7.04-7.10(\mathrm{~m}, 4 \mathrm{H})$. MS (ESI+): $m / z[\mathrm{M}+\mathrm{Na}]^{+} 326.21$; found 326.73 .

tert-Butyl 4-(4-Isopropylphenethyl)piperidine-1-carboxylate (60). Synthesized from a mixture of 38 and $39(0.870 \mathrm{~g}, 2.64$ mmol, 1.0 equiv) via general procedure C. Yield: $83 \%(0.727 \mathrm{~g})$; colorless oil. ${ }^{1} \mathrm{H}$ NMR $\left(400 \mathrm{MHz}, \mathrm{CDCl}_{3}\right): \delta 1.16$ (ddd, $J=16.9$, $12.9,5.5 \mathrm{~Hz}, 2 \mathrm{H}), 1.27$ (d, $J=7.0 \mathrm{~Hz}, 6 \mathrm{H}), 1.40-1.47(\mathrm{~m}, 1 \mathrm{H}), 1.49$ $(\mathrm{s}, 9 \mathrm{H}), 1.54-1.61(\mathrm{~m}, 2 \mathrm{H}), 1.70-1.76(\mathrm{~m}, 2 \mathrm{H}), 2.61-2.64(\mathrm{~m}, 2 \mathrm{H})$, $2.70(\mathrm{t}, J=11.5 \mathrm{~Hz}, 2 \mathrm{H}), 2.91$ (sept. $J=6.9 \mathrm{~Hz}, 1 \mathrm{H}), 4.10$ (bs, $2 \mathrm{H})$, 7.11-7.13 (m, 2H), 7.16-7.18 (m, 2H). MS (ESI+): $m / z[\mathrm{M}+\mathrm{Na}]^{+}$ 354.24; found 354.05.

tert-Butyl 4-(4-Chlorophenethyl)piperidine-1-carboxylate (61). Synthesized from a mixture of 40 and 41 (0.850 g, 2.64 mmol, 1.0 equiv) via general procedure $\mathrm{C}$. Column chromatography, petroleum ether $/ \mathrm{Et}_{2} \mathrm{O}=3 / 1(\mathrm{v} / \mathrm{v})$. Yield: $86 \%(0.736 \mathrm{~g})$; colorless oil. ${ }^{1} \mathrm{H}$ NMR (400 MHz, $\left.\mathrm{CDCl}_{3}\right): \delta 1.08(\mathrm{dd}, J=12.3,4.2 \mathrm{~Hz}, 1 \mathrm{H})$, $1.11(\mathrm{dd}, J=12.8,3.9 \mathrm{~Hz}, 1 \mathrm{H}), 1.33-1.40(\mathrm{~m}, 1 \mathrm{H}), 1.44(\mathrm{~s}, 9 \mathrm{H})$, $1.48-1.53(\mathrm{~m}, 2 \mathrm{H}), 1.63-1.68(\mathrm{~m}, 2 \mathrm{H}), 2.55-2.59(\mathrm{~m}, 2 \mathrm{H}), 2.64(\mathrm{t}$, $J=11.6 \mathrm{~Hz}, 2 \mathrm{H}), 4.07(\mathrm{bs}, 2 \mathrm{H}), 7.05-7.08(\mathrm{~m}, 2 \mathrm{H}), 7.18-7.22(\mathrm{~m}$, $2 \mathrm{H})$. MS (ESI+): $m / z[\mathrm{M}+\mathrm{Na}]^{+} 346.15$; found 346.55 .

tert-Butyl 4-(4-Methoxyphenethyl)piperidine-1-carboxylate (62). Synthesized from a mixture of 44 and $45(0.250 \mathrm{~g}, 0.79 \mathrm{mmol}$, 1.0 equiv) via general procedure C. Yield: $86 \%(0.245 \mathrm{~g})$; colorless oil. ${ }^{1} \mathrm{H}$ NMR (400 MHz, $\left.\mathrm{CDCl}_{3}\right): \delta 1.12(\mathrm{ddd}, J=16.3,12.5,4.3 \mathrm{~Hz}$, $2 \mathrm{H}), 1.35-1.43(\mathrm{~m}, 1 \mathrm{H}), 1.45(\mathrm{~s}, 9 \mathrm{H}), 1.50-1.56(\mathrm{~m}, 2 \mathrm{H}), 1.64-$ $1.71(\mathrm{~m}, 2 \mathrm{H}), 2.55-2.59(\mathrm{~m}, 2 \mathrm{H}), 2.66(\mathrm{t}, J=11.8 \mathrm{~Hz}, 2 \mathrm{H}), 3.79(\mathrm{~s}$, $3 \mathrm{H}), 4.07$ (bs, $2 \mathrm{H}), 6.81-6.84(\mathrm{~m}, 2 \mathrm{H}), 7.07-7.10(\mathrm{~m}, 2 \mathrm{H})$. MS (ESI+): $m / z[\mathrm{M}+\mathrm{Na}]^{+} 342.20$; found 342.59 .

tert-Butyl 4-(4-(Trifluoromethyl)phenethyl)piperidine-1carboxylate (63). Synthesized from a mixture of 46 and $47(0.24$ g, $0.68 \mathrm{mmol}, 1.0$ equiv) via general procedure C. Yield: quantitative; yellow oil. ${ }^{1} \mathrm{H}$ NMR $\left(400 \mathrm{MHz}, \mathrm{CDCl}_{3}\right): \delta 1.12(\mathrm{dt}, J=12.4,4.2 \mathrm{~Hz}$, $1 \mathrm{H}), 1.15(\mathrm{dt}, J=12.3,4.3 \mathrm{~Hz}, 1 \mathrm{H}), 1.36-1.44(\mathrm{~m}, 1 \mathrm{H}), 1.45(\mathrm{~s}$, $9 \mathrm{H}), 1.53-1.61(\mathrm{~m}, 2 \mathrm{H}), 1.65-1.73(\mathrm{~m}, 2 \mathrm{H}), 2.60-2.70(\mathrm{~m}, 4 \mathrm{H})$, $4.08(\mathrm{bs}, 2 \mathrm{H}), 7.25-7.28(\mathrm{~m}, 2 \mathrm{H}), 7.50-7.53(\mathrm{~m}, 2 \mathrm{H})$.

tert-Butyl 4-(3-(Trifluoromethyl)phenethyl)piperidine-1carboxylate (64). Synthesized from a mixture of 48 and $49(0.27$ g, $0.76 \mathrm{mmol}, 1.0$ equiv) via general procedure C. Yield: quantitative; colorless oil. ${ }^{1} \mathrm{H}$ NMR $\left(400 \mathrm{MHz}, \mathrm{CDCl}_{3}\right): \delta 1.13(\mathrm{dt}, J=12.2,4.2$ $\mathrm{Hz}, 1 \mathrm{H}), 1.16(\mathrm{dt}, J=12.4,4.2 \mathrm{~Hz}, 1 \mathrm{H}), 1.37-1.45(\mathrm{~m}, 1 \mathrm{H}), 1.46(\mathrm{~s}$, $9 \mathrm{H}), 1.55-1.61(\mathrm{~m}, 2 \mathrm{H}), 1.67-1.74(\mathrm{~m}, 2 \mathrm{H}), 2.63-2.72(\mathrm{~m}, 4 \mathrm{H})$, 4.09 (bs, 2H), 7.34-7.45 (m, 4H). MS (ESI +$): m / z[\mathrm{M}+\mathrm{Na}]^{+}$ 380.18; found 380.77 .

tert-Butyl 4-(4-Cyanophenethyl)piperidine-1-carboxylate (65). Synthesized from a mixture of $\mathbf{5 0}$ and 51 (0.658 g, 2.11 mmol, 1.0 equiv) via general procedure C. Column chromatography, petroleum ether $/ \mathrm{Et}_{2} \mathrm{O}=3 / 1(\mathrm{v} / \mathrm{v})$. Yield: $95 \%(0.632 \mathrm{~g})$; colorless oil. ${ }^{1} \mathrm{H}$ NMR $\left(400 \mathrm{MHz}, \mathrm{CDCl}_{3}\right): \delta 1.09(\mathrm{dd}, J=12.4,4.2 \mathrm{~Hz}, 1 \mathrm{H})$, $1.12(\mathrm{dd}, J=12.5,4.3 \mathrm{~Hz}, 1 \mathrm{H}), 1.34-1.40(\mathrm{~m}, 1 \mathrm{H}), 1.42(\mathrm{~s}, 9 \mathrm{H})$, $1.51-1.58(\mathrm{~m}, 2 \mathrm{H}), 1.63-1.68(\mathrm{~m}, 2 \mathrm{H}), 2.61-2.68(\mathrm{~m}, 4 \mathrm{H}), 4.06$ (bs, $2 \mathrm{H}), 7.23-7.25(\mathrm{~m}, 2 \mathrm{H}), 7.51-7.54(\mathrm{~m}, 2 \mathrm{H}) . \mathrm{MS}$ (ESI+): $\mathrm{m} / z$ $[\mathrm{M}+\mathrm{Na}]^{+} 337.19$; found 337.07.

tert-Butyl 4-(4-Propylphenethyl)piperidine-1-carboxylate (66). Synthesized from a mixture of $\mathbf{5 4}$ and 55 (0.216 g, 0.660 mmol, 1.0 equiv) via general procedure $C$. The reaction conditions applied resulted in cyclopropyl ring opening to yield the titled compound. Yield: $92 \%(0.200 \mathrm{~g})$; colorless oil. ${ }^{1} \mathrm{H}$ NMR $(400 \mathrm{MHz}$, $\left.\mathrm{CDCl}_{3}\right): \delta 0.95(\mathrm{t}, J=7.3 \mathrm{~Hz}, 3 \mathrm{H}), 1.07-1.17(\mathrm{~m}, 2 \mathrm{H}), 1.37-1.45$ $(\mathrm{m}, 1 \mathrm{H}), 1.45(\mathrm{~s}, 9 \mathrm{H}), 1.52-1.67(\mathrm{~m}, 6 \mathrm{H}), 2.53-2.61(\mathrm{~m}, 4 \mathrm{H}), 2.67$ $(\mathrm{t}, J=13.0 \mathrm{~Hz}, 2 \mathrm{H}), 4.07(\mathrm{bs}, 2 \mathrm{H}), 7.06-7.11(\mathrm{~m}, 4 \mathrm{H}) .{ }^{13} \mathrm{C}$ NMR $\left(100 \mathrm{MHz}, \mathrm{CDCl}_{3}\right): \delta 13.89,24.63,28.47,32.11,32.48,35.53,37.64$, $38.41,43.98,79.17,128.10,128.40,139.65,140.03,154.89$. HRMS (ESI+): $m / z$ calcd for $\mathrm{C}_{21} \mathrm{H}_{33} \mathrm{O}_{2} \mathrm{NNa}[\mathrm{M}+\mathrm{Na}]^{+}$354.2404; found 354.2401 .

(Z)-1-(Prop-2-yn-1-yl)-4-styrylpiperidine (67). Synthesized from $28(0.100 \mathrm{~g}, 0.348 \mathrm{mmol}, 1.0$ equiv $)$ via general procedures $\mathrm{D}$ and E. Column chromatography, EtOAc/n-hex $=1 / 1(\mathrm{v} / \mathrm{v})$. Yield: $82 \%$ (64 mg); white crystals, mp $42-43{ }^{\circ} \mathrm{C} .{ }^{1} \mathrm{H}$ NMR (400 MHz, $\left.\mathrm{CDCl}_{3}\right): \delta 1.50-1.60(\mathrm{~m}, 2 \mathrm{H}), 1.74(\mathrm{bd}, J=16.0 \mathrm{~Hz}, 2 \mathrm{H}), 2.19-2.26$ (m, 3H), 2.52-2.62 (m, $1 \mathrm{H}), 2.86-2.90(\mathrm{~m}, 2 \mathrm{H}), 3.29(\mathrm{~d}, J=2.4 \mathrm{~Hz}$, $2 \mathrm{H}), 5.49(\mathrm{dd}, J=11.4,10.3 \mathrm{~Hz}, 1 \mathrm{H}), 6.38(\mathrm{~d}, J=11.7 \mathrm{~Hz}, 1 \mathrm{H})$, 7.21-7.25 (m, 3H), 7.31-7.35 (m, 2H). ${ }^{13} \mathrm{C}$ NMR (100 MHz, $\left.\mathrm{CDCl}_{3}\right): \delta 32.29,34.38,47.23,51.87,72.93,79.03,126.55,128.03$, $128.18,128.45,137.19,137.57$. HRMS (ESI+): $\mathrm{m} / \mathrm{z}$ calcd for $\mathrm{C}_{16} \mathrm{H}_{20} \mathrm{~N}[\mathrm{M}+\mathrm{H}]^{+}$226.1596; found 226.1598. IR (ATR): 3210, $2988,2945,2917,2800,1498,1446,1425,1330,1311,1127,1103$, $1073,969,904,799,775,727,696,670,560 \mathrm{~cm}^{-1}$. HPLC purity, $99.9 \%\left(t_{\mathrm{R}}=8.86 \mathrm{~min}\right)$.

(E)-1-(Prop-2-yn-1-yl)-4-styrylpiperidine (68). Synthesized from $29(0.196 \mathrm{~g}, 0.682 \mathrm{mmol}, 1.0$ equiv $)$ via general procedures $\mathrm{D}$ and E. Column chromatography, EtOAc/n-hex $=1 / 1(\mathrm{v} / \mathrm{v})$. Yield: $89 \%$ (137 mg); white crystals, mp 44-46 ${ }^{\circ} \mathrm{C} .{ }^{1} \mathrm{H}$ NMR $(400 \mathrm{MHz}$, $\left.\mathrm{CDCl}_{3}\right): \delta 1.56(\mathrm{dd}, J=11.9,3.9 \mathrm{~Hz}, 1 \mathrm{H}), 1.59(\mathrm{dd}, J=11.9,3.9 \mathrm{~Hz}$, $1 \mathrm{H}), 1.79-1.84(\mathrm{~m}, 2 \mathrm{H}), 2.09-2.19(\mathrm{~m}, 1 \mathrm{H}), 2.25-2.31(\mathrm{~m}, 3 \mathrm{H})$, $2.94(\mathrm{td}, J=11.1,2.4 \mathrm{~Hz}, 2 \mathrm{H}), 3.33(\mathrm{~d}, J=2.5 \mathrm{~Hz}, 2 \mathrm{H}), 6.18(\mathrm{dd}, J=$ 16.0, $7.0 \mathrm{~Hz}, 1 \mathrm{H}), 6.39(\mathrm{~d}, J=16.5 \mathrm{~Hz}, 1 \mathrm{H}), 7.18-7.22(\mathrm{~m}, 1 \mathrm{H})$, $7.26-7.32(\mathrm{~m}, 2 \mathrm{H}), 7.34-7.37(\mathrm{~m}, 2 \mathrm{H}) .{ }^{13} \mathrm{C}$ NMR $(100 \mathrm{MHz}$, $\left.\mathrm{CDCl}_{3}\right): \delta 31.91,38.71,47.13,52.13,72.91,78.98,125.87,126.85$, $128.10,128.35,134.76,137.47$. HRMS (ESI+): $\mathrm{m} / \mathrm{z}$ calcd for $\mathrm{C}_{16} \mathrm{H}_{20} \mathrm{~N}[\mathrm{M}+\mathrm{H}]^{+}$226.1596; found 226.1594. IR (ATR): 3264, 2929, 2909, 2805, 1446, 1429, 1315, 1223, 1135, 1106, 976, 962, 897, $744,686,670,619,519 \mathrm{~cm}^{-1}$. HPLC purity, $99.2 \%\left(t_{\mathrm{R}}=8.90 \mathrm{~min}\right)$.

(Z)-4-(3-Fluorostyryl)-1-(prop-2-yn-1-yl)piperidine (69). Synthesized from 30 (110 mg, $0.360 \mathrm{mmol}, 1.0$ equiv) via general procedures D and E. Column chromatography, EtOAc/n-hex $=1 / 2$ (v/v). Yield: $12 \%(11 \mathrm{mg})$; yellow crystals, mp $51-53{ }^{\circ} \mathrm{C} .{ }^{1} \mathrm{H}$ NMR $\left(400 \mathrm{MHz}, \mathrm{CDCl}_{3}\right): \delta 1.49-1.60(\mathrm{~m}, 2 \mathrm{H}), 1.69-1.76(\mathrm{~m}, 2 \mathrm{H}), 2.23$ $(\mathrm{dt}, J=11.7,2.5 \mathrm{~Hz}, 2 \mathrm{H}), 2.24(\mathrm{t}, J=2.4 \mathrm{~Hz}, 1 \mathrm{H}), 2.48-2.58(\mathrm{~m}$, $1 \mathrm{H}), 2.86-2.91(\mathrm{~m}, 2 \mathrm{H}), 3.30(\mathrm{~d}, J=2.4 \mathrm{~Hz}, 2 \mathrm{H}), 5.53(\mathrm{dd}, J=11.6$, $10.2 \mathrm{~Hz}, 1 \mathrm{H}), 6.33(\mathrm{~d}, J=11.7 \mathrm{~Hz}, 1 \mathrm{H}), 6.90-6.95(\mathrm{~m}, 2 \mathrm{H}), 6.99-$ $7.01(\mathrm{~m}, 1 \mathrm{H}), 7.26-7.31(\mathrm{~m}, 1 \mathrm{H}) .{ }^{13} \mathrm{C}$ NMR $\left(100 \mathrm{MHz}, \mathrm{CDCl}_{3}\right): \delta$ $32.16,34.45,47.23,51.81,73.02,78.96,113.44\left(\mathrm{~d}, J_{\mathrm{C}, \mathrm{F}}=21.2 \mathrm{~Hz}\right)$, $115.17\left(\mathrm{~d}, J_{\mathrm{C}, \mathrm{F}}=21.3 \mathrm{~Hz}\right), 124.22\left(\mathrm{~d}, J_{\mathrm{C}, \mathrm{F}}=2.8 \mathrm{~Hz}\right), 127.01\left(\mathrm{~d}, J_{\mathrm{C}, \mathrm{F}}=\right.$ $2.1 \mathrm{~Hz}), 129.62\left(\mathrm{~d}, J_{\mathrm{C}, \mathrm{F}}=8.6 \mathrm{~Hz}\right), 138.29,139.76\left(\mathrm{~d}, J_{\mathrm{C}, \mathrm{F}}=7.9 \mathrm{~Hz}\right)$, $162.66\left(\mathrm{~d}, J_{\mathrm{CF}}=245.2 \mathrm{~Hz}\right)$. HRMS (ESI $): \mathrm{m} / z$ calcd for $\mathrm{C}_{16} \mathrm{H}_{19} \mathrm{FN}$ $[\mathrm{M}+\mathrm{H}]^{+}$244.1502; found 244.1504. IR (ATR): 3304, 2924, 2851, $2805,2755,1611,1580,1513,1487,1465,1444,1386,1364,1335$, $1311,1272,1247,1231,1138,1124,1105,1073,1018,973,937,923$, $878,792,764,752,694,667,634 \mathrm{~cm}^{-1}$. HPLC purity, $97.9 \%\left(t_{\mathrm{R}}=\right.$ $9.10 \mathrm{~min})$.

(E)-4-(3-Fluorostyryl)-1-(prop-2-yn-1-yl)piperidine (70). Synthesized from $31(0.300 \mathrm{~g}, 0.982 \mathrm{mmol}, 1.0 \mathrm{equiv})$ via general procedures D and E. Column chromatography, EtOAc/n-hex $=1 / 2$ (v/v). Yield: $38 \%(91 \mathrm{mg})$; pale yellow oil. ${ }^{1} \mathrm{H}$ NMR $(400 \mathrm{MHz}$, $\left.\mathrm{CDCl}_{3}\right): \delta 1.57(\mathrm{dt}, J=12.0,3.9 \mathrm{~Hz}, 1 \mathrm{H}), 1.60(\mathrm{dt}, J=11.9,3.9 \mathrm{~Hz}$, $1 \mathrm{H}), 1.78-1.84(\mathrm{~m}, 2 \mathrm{H}), 2.10-2.19(\mathrm{~m}, 1 \mathrm{H}), 2.27(\mathrm{t}, J=2.5 \mathrm{~Hz}$, $1 \mathrm{H}), 2.31(\mathrm{dt}, J=11.7,2.5 \mathrm{~Hz}, 2 \mathrm{H}), 2.93-2.98(\mathrm{~m}, 2 \mathrm{H}), 3.35(\mathrm{~d}, J=$ $2.5 \mathrm{~Hz}, 2 \mathrm{H}), 6.17(\mathrm{dd}, J=16.0,6.9 \mathrm{~Hz}, 1 \mathrm{H}), 6.34(\mathrm{~d}, J=16.0 \mathrm{~Hz}$, $1 \mathrm{H}), 6.88$ (ddt, $J=8.4,2.6,0.9 \mathrm{~Hz}, 1 \mathrm{H}), 7.02-7.06(\mathrm{~m}, 1 \mathrm{H}), 7.07-$ $7.11(\mathrm{~m}, 1 \mathrm{H}), 7.21-7.27(\mathrm{~m}, 1 \mathrm{H}) .{ }^{13} \mathrm{C} \mathrm{NMR}\left(100 \mathrm{MHz}, \mathrm{CDCl}_{3}\right): \delta$ 
$31.71,38.64,47.15,52.10,73.32,78.62,112.39\left(\mathrm{~d}, J_{\mathrm{C}, \mathrm{F}}=22.0 \mathrm{~Hz}\right)$, $113.73\left(\mathrm{~d}, J_{\mathrm{C}, \mathrm{F}}=21.3 \mathrm{~Hz}\right), 121.87\left(\mathrm{~d}, J_{\mathrm{C}, \mathrm{F}}=2.9 \mathrm{~Hz}\right), 127.33\left(\mathrm{~d}, J_{\mathrm{C}, \mathrm{F}}=\right.$ $2.9 \mathrm{~Hz}), 129.84\left(\mathrm{~d}, J_{\mathrm{C}, \mathrm{F}}=8.7 \mathrm{~Hz}\right), 136.10,139.94\left(\mathrm{~d}, J_{\mathrm{C}, \mathrm{F}}=7.3 \mathrm{~Hz}\right)$, $163.06\left(\mathrm{~d}, J_{\mathrm{C}, \mathrm{F}}=244.9 \mathrm{~Hz}\right)$. HRMS (ESI +$): m / z$ calcd for $\mathrm{C}_{16} \mathrm{H}_{19} \mathrm{FN}$ $[\mathrm{M}+\mathrm{H}]^{+}$244.1502; found 244.1504. IR (ATR): 3303, 2931, 2808, $2751,1651,1611,1583,491,1466,1445,1385,1364,1336,1312$, $1267,1245,1140,1106,1074,962,939,897,873,829,809,777,684$, $631,590 \mathrm{~cm}^{-1}$. HPLC purity, $99.6 \%\left(t_{\mathrm{R}}=9.15 \mathrm{~min}\right)$.

(Z)-4-(2-Fluorostyryl)-1-(prop-2-yn-1-yl)piperidine (71). Synthesized $32(225 \mathrm{mg}, 0.737 \mathrm{mmol}, 1.0$ equiv) via general procedures $\mathrm{D}$ and E. Column chromatography, EtOAc/n-hex $=1 / 2(\mathrm{v} / \mathrm{v})$. Yield: $5 \%$ (9 mg); colorless oil. ${ }^{1} \mathrm{H}$ NMR (400 MHz, $\left.\mathrm{CDCl}_{3}\right): \delta 1.49-1.59$ $(\mathrm{m}, 2 \mathrm{H}), 1.68-1.75(\mathrm{~m}, 2 \mathrm{H}), 2.16-2.23(\mathrm{~m}, 2 \mathrm{H}), 2.23(\mathrm{t}, J=2.4 \mathrm{~Hz}$, $1 \mathrm{H}), 2.33-2.43(\mathrm{~m}, 1 \mathrm{H}), 2.85-2.90(\mathrm{~m}, 2 \mathrm{H}), 3.30(\mathrm{~d}, J=2.4 \mathrm{~Hz}$, $2 \mathrm{H}), 5.62(\mathrm{dd}, J=11.6,10.2 \mathrm{~Hz}, 1 \mathrm{H}), 6.37(\mathrm{~d}, J=11.4 \mathrm{~Hz}, 1 \mathrm{H})$, 7.03-7.08 (m, 1H), 7.09-7.13 (m, 1H), 7.21-7.26 (m, 2H). ${ }^{13} \mathrm{C}$ $\operatorname{NMR}\left(100 \mathrm{MHz}, \mathrm{CDCl}_{3}\right): \delta 32.11,34.98,47.28,51.89,72.94,79.08$, $115.43\left(\mathrm{~d}, J_{\mathrm{C}, \mathrm{F}}=22.3 \mathrm{~Hz}\right), 120.66\left(\mathrm{~d}, J_{\mathrm{C}, \mathrm{F}}=3.0 \mathrm{~Hz}\right), 123.66\left(\mathrm{~d}, J_{\mathrm{C}, \mathrm{F}}=\right.$ $3.6 \mathrm{~Hz}), 125.22\left(\mathrm{~d}, J_{\mathrm{C}, \mathrm{F}}=15.0 \mathrm{~Hz}\right), 128.45\left(\mathrm{~d}, J_{\mathrm{C}, \mathrm{F}}=8.2 \mathrm{~Hz}\right), 130.28$ $\left(\mathrm{d}, J_{\mathrm{C}, \mathrm{F}}=3.7 \mathrm{~Hz}\right), 139.25,160.03\left(\mathrm{~d}, J_{\mathrm{C}, \mathrm{F}}=246.6 \mathrm{~Hz}\right)$. HRMS (ESI+): $\mathrm{m} / z$ calcd for $\mathrm{C}_{16} \mathrm{H}_{19} \mathrm{FN}[\mathrm{M}+\mathrm{H}]^{+} 244.1502$; found 244.1505. IR (ATR): 3300, 2918, 2802, 2754, 1485, 1451, 1334, 1310, 1272, 1232, $1134,1095,972,835,780,758,634 \mathrm{~cm}^{-1}$. HPLC purity, $97.1 \%\left(t_{\mathrm{R}}=\right.$ $9.04 \mathrm{~min})$.

(E)-4-(2-Fluorostyryl)-1-(prop-2-yn-1-yl)piperidine (72). Synthesized from $33(0.180 \mathrm{~g}, 0.589 \mathrm{mmol}, 1.0$ equiv $)$ via general procedures D and E. Column chromatography, EtOAc/n-hex $=1 / 2$ (v/v). Yield: $58 \%(83 \mathrm{mg})$; pale yellow oil. ${ }^{1} \mathrm{H}$ NMR $(400 \mathrm{MHz}$, $\left.\mathrm{CDCl}_{3}\right): \delta 1.56(\mathrm{dt}, J=12.0,3.9 \mathrm{~Hz}, 1 \mathrm{H}), 1.59(\mathrm{dt}, J=12.0,3.9 \mathrm{~Hz}$, $1 \mathrm{H}), 1.79-1.85(\mathrm{~m}, 2 \mathrm{H}), 2.12-2.20(\mathrm{~m}, 1 \mathrm{H}), 2.25(\mathrm{t}, J=2.4 \mathrm{~Hz}$, $1 \mathrm{H}), 2.28(\mathrm{dt}, J=11.7,2.5 \mathrm{~Hz}, 2 \mathrm{H}), 2.91-2.96(\mathrm{~m}, 2 \mathrm{H}), 3.33(\mathrm{~d}, J=$ $2.4 \mathrm{~Hz}, 2 \mathrm{H}), 6.23(\mathrm{dd}, J=16.1,7.1 \mathrm{~Hz}, 1 \mathrm{H}), 6.55(\mathrm{~d}, J=16.1 \mathrm{~Hz}$, $1 \mathrm{H}), 7.00(\mathrm{ddd}, J=10.8,8.1,1.2 \mathrm{~Hz}, 1 \mathrm{H}), 7.07(\mathrm{dt}, J=7.4,1.0 \mathrm{~Hz}$, $1 \mathrm{H}), 7.14-7.19(\mathrm{~m}, 1 \mathrm{H}), 7.44(\mathrm{dt}, J=7.7,1.7 \mathrm{~Hz}, 1 \mathrm{H}) .{ }^{13} \mathrm{C} \mathrm{NMR}$ $\left(100 \mathrm{MHz} \mathrm{CDCl}_{3}\right): \delta 31.93,39.22,47.24,52.21,72.97,79.06,115.58$ $\left(\mathrm{d}, J_{\mathrm{C}, \mathrm{F}}=22.3 \mathrm{~Hz}\right), 120.59\left(\mathrm{~d}, J_{\mathrm{C}, \mathrm{F}}=3.8 \mathrm{~Hz}\right), 123.95\left(\mathrm{~d}, J_{\mathrm{C}, \mathrm{F}}=3.6\right.$ $\mathrm{Hz}), 125.32\left(\mathrm{~d}, J_{\mathrm{C}, \mathrm{F}}=12.3 \mathrm{~Hz}\right), 126.88\left(\mathrm{~d}, J_{\mathrm{C}, \mathrm{F}}=12.3 \mathrm{~Hz}\right), 128.14(\mathrm{~d}$, $\left.J_{\mathrm{C}, \mathrm{F}}=8.5 \mathrm{~Hz}\right), 137.41\left(\mathrm{~d}, J_{\mathrm{C}, \mathrm{F}}=4.2 \mathrm{~Hz}\right), 159.94\left(\mathrm{~d}, J_{\mathrm{C}, \mathrm{F}}=248.4 \mathrm{~Hz}\right)$. HRMS (ESI+): $m / z$ calcd for $\mathrm{C}_{16} \mathrm{H}_{19} \mathrm{FN}[\mathrm{M}+\mathrm{H}]^{+} 244.1502$; found 244.1500. IR (ATR): 3183, 2947, 2921, 2802, 2756, 1576, 1485, $1455,1445,1389,1371,1360,1331,1301,1277,1263,1230,1213$, 1194, 1183, 1141, 1108, 1091, 1031, 1020, 983, 968, 946, 842, 811, $777,754,713 \mathrm{~cm}^{-1}$. HPLC purity, $99.5 \%\left(t_{\mathrm{R}}=9.09 \mathrm{~min}\right)$.

(Z)-4-(2-Chloro-4-fluorostyryl)-1-(prop-2-yn-1-yl)piperidine (73). Synthesized from $34(110 \mathrm{mg}, 0.324 \mathrm{mmol}, 1.0$ equiv) via general procedures $\mathrm{D}$ and $\mathrm{E}$. Column chromatography, EtOAc/n-hex

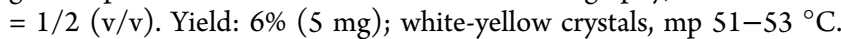
${ }^{1} \mathrm{H}$ NMR $\left(400 \mathrm{MHz}, \mathrm{CDCl}_{3}\right): \delta 1.48-1.58(\mathrm{~m}, 2 \mathrm{H}), 1.64-1.69(\mathrm{~m}$, $2 \mathrm{H}), 2.13-2.30(\mathrm{~m}, 3 \mathrm{H}), 2.23(\mathrm{t}, J=2.4 \mathrm{~Hz}, 1 \mathrm{H}), 2.83-2.88(\mathrm{~m}$, $2 \mathrm{H}), 3.28(\mathrm{~d}, J=2.4 \mathrm{~Hz}, 2 \mathrm{H}), 5.61(\mathrm{dd}, J=10.8,10.4 \mathrm{~Hz}, 1 \mathrm{H}), 6.35$ $(\mathrm{d}, J=11.5 \mathrm{~Hz}, 1 \mathrm{H}), 6.96(\mathrm{dt}, J=8.4,2.4 \mathrm{~Hz}, 1 \mathrm{H}), 7.14(\mathrm{dd}, J=8.4$, $2.4 \mathrm{~Hz}, 1 \mathrm{H}), 7.19(\mathrm{dd}, J=8.2,6.4 \mathrm{~Hz}, 1 \mathrm{H}) .{ }^{13} \mathrm{C}$ NMR $(100 \mathrm{MHz}$, $\left.\mathrm{CDCl}_{3}\right): \delta 32.09,34.57,47.23,51.78,72.99,78.97,113.64\left(\mathrm{~d}, J_{\mathrm{C}, \mathrm{F}}=\right.$ $20.7 \mathrm{~Hz}), 116.70\left(\mathrm{~d}, J_{\mathrm{C}, \mathrm{F}}=24.8 \mathrm{~Hz}\right), 124.51,130.93\left(\mathrm{~d}, J_{\mathrm{C}, \mathrm{F}}=8.3\right.$ $\mathrm{Hz}), 132.06\left(\mathrm{~d}, J_{\mathrm{C}, \mathrm{F}}=3.7 \mathrm{~Hz}\right), 134.16\left(\mathrm{~d}, J_{\mathrm{C}, \mathrm{F}}=10.2 \mathrm{~Hz}\right), 138.65$, $161.35\left(\mathrm{~d}, J_{\mathrm{C}, \mathrm{F}}=248.6 \mathrm{~Hz}\right.$ ). HRMS (ESI +$): \mathrm{m} / z$ calcd for $\mathrm{C}_{16} \mathrm{H}_{18} \mathrm{FClN}[\mathrm{M}+\mathrm{H}]^{+}$278.1112; found 244.1105. IR (ATR): $3166,3010,2932,2789,2758,1601,1574,1485,1467,1445,1403$, $1390,1367,1331,1307,1295,1271,1257,1230,1221,1210,1169$, $1142,1121,1109,1064,1041,1016,1006,973,951,901,875,863$, $821,790,768,747,704,687,643,615,583,547 \mathrm{~cm}^{-1}$. HPLC purity, $99.7 \%\left(t_{\mathrm{R}}=9.85 \mathrm{~min}\right)$.

(E)-4-(2-Chloro-4-fluorostyryl)-1-(prop-2-yn-1-yl)piperidine (74). Synthesized from 35 (0.263 g, $0.774 \mathrm{mmol}, 1.0$ equiv) via general procedures D and E. Column chromatography, EtOAc/n-hex $=1 / 2(\mathrm{v} / \mathrm{v})$. Yield: $58 \%(125 \mathrm{mg})$; pale yellow oil. ${ }^{1} \mathrm{H}$ NMR $(400$ $\left.\mathrm{MHz}, \mathrm{CDCl}_{3}\right): \delta 1.56(\mathrm{dt}, J=12.0,3.9 \mathrm{~Hz}, 1 \mathrm{H}), 1.59(\mathrm{dt}, J=11.9,3.9$ $\mathrm{Hz}, 1 \mathrm{H}), 1.77-1.85(\mathrm{~m}, 2 \mathrm{H}), 2.12-2.23(\mathrm{~m}, 1 \mathrm{H}), 2.25(\mathrm{t}, J=2.4 \mathrm{~Hz}$, $1 \mathrm{H}), 2.28(\mathrm{dt}, J=11.7,2.5 \mathrm{~Hz}, 2 \mathrm{H}), 2.91-2.96(\mathrm{~m}, 2 \mathrm{H}), 3.32(\mathrm{~d}, J=$ $2.4 \mathrm{~Hz}, 2 \mathrm{H}), 6.07(\mathrm{dd}, J=15.9,7.1 \mathrm{~Hz}, 1 \mathrm{H}), 6.68(\mathrm{~d}, J=15.9 \mathrm{~Hz}$,
$1 \mathrm{H}), 6.90-6.95(\mathrm{~m}, 1 \mathrm{H}), 7.08(\mathrm{dd}, J=8.5,2.6 \mathrm{~Hz}, 1 \mathrm{H}), 7.47(\mathrm{dt}, J=$ 8.8, 6.1 Hz, $1 \mathrm{H}) .{ }^{13} \mathrm{C} \mathrm{NMR}\left(100 \mathrm{MHz}, \mathrm{CDCl}_{3}\right): \delta 31.88,38.93$, $47.18,52.10,72.95,78.98,114.11\left(\mathrm{~d}, J_{\mathrm{C}, \mathrm{F}}=21.3 \mathrm{~Hz}\right), 116.56\left(\mathrm{~d}, J_{\mathrm{C}, \mathrm{F}}=\right.$ $24.7 \mathrm{~Hz}), 123.61\left(\mathrm{~d}, J_{\mathrm{C}, \mathrm{F}}=1.1 \mathrm{~Hz}\right), 127.48\left(\mathrm{~d}, J_{\mathrm{C}, \mathrm{F}}=8.8 \mathrm{~Hz}\right), 131.97$ $\left(\mathrm{d}, J_{\mathrm{C}, \mathrm{F}}=3.7 \mathrm{~Hz}\right), 133.00\left(\mathrm{~d}, J_{\mathrm{C}, \mathrm{F}}=10.2 \mathrm{~Hz}\right), 137.51\left(\mathrm{~d}, J_{\mathrm{C}, \mathrm{F}}=1.7\right.$ $\mathrm{Hz}), 161.32\left(\mathrm{~d}, J_{\mathrm{C}, \mathrm{F}}=249.4 \mathrm{~Hz}\right)$. HRMS (ESI $): \mathrm{m} / z$ calcd for $\mathrm{C}_{16} \mathrm{H}_{18} \mathrm{FClN}[\mathrm{M}+\mathrm{H}]^{+}$278.1112; found 278.1120. IR (ATR): 3303, $2933,2803,2753,1650,1600,1574,1466,1445,1396,1364,1336$, $1312,1269,1258,1237,1183,1137,1122,1040,966,904,858,805$, $776,760,686,627,579 \mathrm{~cm}^{-1}$. HPLC purity, $100 \%\left(t_{\mathrm{R}}=9.86 \mathrm{~min}\right)$.

(Z)-4-(4-Methylstyryl)-1-(prop-2-yn-1-yl)piperidine (75). Synthesized from $36(0.07 \mathrm{~g}, 0.23 \mathrm{mmol}, 1.0$ equiv $)$ via general procedures D and E. Column chromatography, EtOAc/n-hex $=1 / 2$ (v/v). Yield: $49 \%\left(27 \mathrm{mg}\right.$ ); yellow crystals, mp $85-86{ }^{\circ} \mathrm{C} .{ }^{1} \mathrm{H}$ NMR $\left(400 \mathrm{MHz}, \mathrm{CDCl}_{3}\right): \delta 1.49-1.57(\mathrm{~m}, 2 \mathrm{H}), 1.72-1.76(\mathrm{~m}, 2 \mathrm{H})$, $2.20-2.26(\mathrm{~m}, 3 \mathrm{H}), 2.35(\mathrm{~s}, 3 \mathrm{H}), 2.52-2.62(\mathrm{~m}, 1 \mathrm{H}), 2.86-2.91(\mathrm{~m}$, $2 \mathrm{H}), 3.30(\mathrm{~d}, J=2.4 \mathrm{~Hz}, 2 \mathrm{H}), 5.45(\mathrm{dd}, J=11.6,10.0 \mathrm{~Hz}, 1 \mathrm{H}), 6.35$ $(\mathrm{d}, J=11.6 \mathrm{~Hz}, 1 \mathrm{H}), 7.15(\mathrm{~s}, 4 \mathrm{H}) .{ }^{13} \mathrm{C} \mathrm{NMR}\left(100 \mathrm{MHz}, \mathrm{CDCl}_{3}\right): \delta$ 21.16, 32.36, 34.45, 47.29, 51.96, 72.94, 79.10, 127.94, 128.43, 128.94, $134.74,136.33,136.62$. HRMS (ESI+): $m / z$ calcd for $\mathrm{C}_{17} \mathrm{H}_{22} \mathrm{~N}[\mathrm{M}+$ $\mathrm{H}]^{+}$240.1752; found 240.1756. IR (ATR): 3210, 2934, 2858, 2798, 2756, 1466, 1450, 1432, 1335, 1272, 1143, 1109, 1067, 972, 946, 836, $824,810,785,738,687,560 \mathrm{~cm}^{-1}$. HPLC purity, $100 \%\left(t_{\mathrm{R}}=9.62\right.$ $\min )$.

(E)-4-(4-Methylstyryl)-1-(prop-2-yn-1-yl)piperidine (76). Synthesized from $37(0.42 \mathrm{~g}, 1.39 \mathrm{mmol}, 1.0$ equiv) via general procedures $\mathrm{D}$ and E. Column chromatography, EtOAc/n-hex $=1 / 3$ (v/v). Yield: $36 \%(121 \mathrm{mg})$; orange crystals, mp $65-67{ }^{\circ} \mathrm{C} .{ }^{1} \mathrm{H} \mathrm{NMR}$ $\left(400 \mathrm{MHz}, \mathrm{CDCl}_{3}\right): \delta 1.62-1.72(\mathrm{~m}, 2 \mathrm{H}), 1.89-1.95(\mathrm{~m}, 2 \mathrm{H})$, $2.18-2.28(\mathrm{~m}, 1 \mathrm{H}), 2.34-2.41(\mathrm{~m}, 3 \mathrm{H}), 2.43(\mathrm{~s}, 3 \mathrm{H}), 3.01-3.06(\mathrm{~m}$, $2 \mathrm{H}), 3.43(\mathrm{~d}, J=2.5 \mathrm{~Hz}, 2 \mathrm{H}), 6.22(\mathrm{dd}, J=16.0,7.0 \mathrm{~Hz}, 1 \mathrm{H}), 6.46$ $(\mathrm{d}, J=15.9 \mathrm{~Hz}, 1 \mathrm{H}), 7.21(\mathrm{~d}, J=7.9 \mathrm{~Hz}, 2 \mathrm{H}), 7.36(\mathrm{~d}, J=8.3 \mathrm{~Hz}$, 2H). ${ }^{13} \mathrm{C}$ NMR $\left(100 \mathrm{MHz}, \mathrm{CDCl}_{3}\right): \delta 21.09,32.04,38.77,47.21$, 52.25, 72.92, 79.07, 125.83, 127.98, 129.13, 133.84, 134.78, 136.62. HRMS (ESI+): $m / z$ calcd for $\mathrm{C}_{17} \mathrm{H}_{22} \mathrm{~N}[\mathrm{M}+\mathrm{H}]^{+} 240.1752$; found 240.1756. IR (ATR): 3209, 2933, 2858, 2800, 2756, 1513, 1450, $1427,1335,1311,1271,1134,1109,1067,1019,972,910,824,795$, $785,739,685,642,561,518 \mathrm{~cm}^{-1}$. HPLC purity, $97.7 \%\left(t_{\mathrm{R}}=9.65\right.$ $\min )$.

(Z)-4-(4-Isopropylstyryl)-1-(prop-2-yn-1-yl)piperidine (77). Synthesized from $38(0.180 \mathrm{~g}, 0.546 \mathrm{mmol}, 1.0$ equiv $)$ via general procedures D and E. Column chromatography, EtOAc/n-hex $=1 / 2$ (v/v). Yield: 79\% (115 mg); colorless oil. ${ }^{1} \mathrm{H}$ NMR (400 MHz, $\left.\mathrm{CDCl}_{3}\right): \delta 1.27(\mathrm{~d}, J=6.9 \mathrm{~Hz}, 6 \mathrm{H}), 1.50-1.60(\mathrm{~m}, 2 \mathrm{H}), 1.74-1.78$ $(\mathrm{m}, 2 \mathrm{H}), 2.21-2.28(\mathrm{~m}, 2 \mathrm{H}), 2.24(\mathrm{t}, J=2.4 \mathrm{~Hz}, 1 \mathrm{H}), 2.56-2.66(\mathrm{~m}$, $1 \mathrm{H}), 2.87-2.95(\mathrm{~m}, 3 \mathrm{H}), 3.31(\mathrm{~d}, J=2.5 \mathrm{~Hz}, 2 \mathrm{H}), 5.45(\mathrm{dd}, J=11.7$, $10.0 \mathrm{~Hz}, 1 \mathrm{H}), 6.35(\mathrm{~d}, J=11.7 \mathrm{~Hz}, 1 \mathrm{H}), 7.17-7.23(\mathrm{~m}, 4 \mathrm{H}) .{ }^{13} \mathrm{C}$ NMR $\left(100 \mathrm{MHz}, \mathrm{CDCl}_{3}\right): \delta 23.95,32.36,33.77,34.44,47.28,51.95$, 72.93, 79.10, 126.29, 127.90, 128.49, 135.09, 136.56, 147.27. HRMS (ESI+): $m / z$ calcd for $\mathrm{C}_{19} \mathrm{H}_{26} \mathrm{~N}[\mathrm{M}+\mathrm{H}]^{+}$268.2065; found 268.2061. IR (ATR): 3295, 2958, 2937, 2801, 1508, 1335, 1311, 1136, 973, 849, $676 \mathrm{~cm}^{-1}$. HPLC purity, $99.1 \%\left(t_{\mathrm{R}}=10.83 \mathrm{~min}\right)$.

(E)-4-(4-Isopropylstyryl)-1-(prop-2-yn-1-yl)piperidine (78). Synthesized from $39(0.207 \mathrm{~g}, 0.628 \mathrm{mmol}, 1.0$ equiv) via general procedures D and E. Column chromatography, EtOAc/n-hex $=1 / 1$ (v/v). Yield: $45 \%$ (76 mg); pale yellow crystals, $\mathrm{mp} 60-64{ }^{\circ} \mathrm{C} .{ }^{1} \mathrm{H}$ NMR $\left(400 \mathrm{MHz}, \mathrm{CDCl}_{3}\right): \delta 1.24(\mathrm{~d}, J=6.9 \mathrm{~Hz}, 6 \mathrm{H}), 1.52-1.61(\mathrm{~m}$, $2 \mathrm{H}), 1.78-1.83(\mathrm{~m}, 2 \mathrm{H}), 2.05-2.20(\mathrm{~m}, 1 \mathrm{H}), 2.24-2.31(\mathrm{~m}, 2 \mathrm{H})$, $2.26(\mathrm{t}, J=2.5 \mathrm{~Hz}, 1 \mathrm{H}), 2.83-2.95(\mathrm{~m}, 3 \mathrm{H}), 3.32(\mathrm{~d}, J=2.5 \mathrm{~Hz}, 2 \mathrm{H})$, $6.13(\mathrm{dd}, J=16.0,7.0 \mathrm{~Hz}, 1 \mathrm{H}), 6.37(\mathrm{~d}, J=16.6 \mathrm{~Hz}, 1 \mathrm{H}), 7.15-7.17$

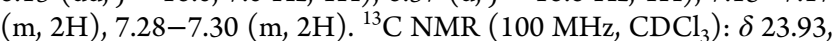
$32.05,33.76,38.76,47.23,52.25,72.90,79.08,125.89,126.549$, 127.96, 134.01, 135.21, 147.73. HRMS (ESI+): $\mathrm{m} / \mathrm{z}$ calcd for $\mathrm{C}_{19} \mathrm{H}_{26} \mathrm{~N}[\mathrm{M}+\mathrm{H}]^{+}$268.2065; found 268.2062. IR (ATR): 3299, 2959, 2936, 2908, 2802, 1514, 1457, 1425, 1384, 1310, 1131, 1103, $1053,977,899,855,812,762,685,654,639,553 \mathrm{~cm}^{-1}$. HPLC purity, $98.5 \%\left(t_{\mathrm{R}}=10.89 \mathrm{~min}\right)$.

(Z)-4-(4-Chlorostyryl)-1-(prop-2-yn-1-yl)piperidine (79). Synthesized from $40(0.150 \mathrm{~g}, 0.466 \mathrm{mmol}, 1.0$ equiv) via general procedures $\mathrm{D}$ and E. Column chromatography, EtOAc/n-hex $=1 / 2$ 
(v/v). Yield: $67 \%$ (81 mg); white crystals, mp 97-99 ${ }^{\circ} \mathrm{C} .{ }^{1} \mathrm{H}$ NMR $\left(400 \mathrm{MHz}, \mathrm{CDCl}_{3}\right): \delta 1.49-1.59(\mathrm{~m}, 2 \mathrm{H}), 1.68-1.74(\mathrm{~m}, 2 \mathrm{H})$, $2.18-2.25(\mathrm{~m}, 2 \mathrm{H}), 2.23(\mathrm{t}, J=2.5 \mathrm{~Hz}, 1 \mathrm{H}), 2.44-2.54(\mathrm{~m}, 1 \mathrm{H})$, $2.85-2.90(\mathrm{~m}, 2 \mathrm{H}), 3.30(\mathrm{~d}, J=2.5 \mathrm{~Hz}, 2 \mathrm{H}), 5.51(\mathrm{dd}, J=11.6,10.1$ $\mathrm{Hz}, 1 \mathrm{H}), 6.32(\mathrm{~d}, J=11.7 \mathrm{~Hz}, 1 \mathrm{H}), 7.14-7.17(\mathrm{~m}, 2 \mathrm{H}), 7.28-7.31$ $(\mathrm{m}, 2 \mathrm{H}) .{ }^{13} \mathrm{C}$ NMR $\left(100 \mathrm{MHz}, \mathrm{CDCl}_{3}\right): \delta 32.20,34.45,47.24,51.83$, 73.01, 78.97, 126.92, 128.37, 129.74, 132.30, 135.99, 137.88. HRMS (ESI+): $m / z$ calcd for $\mathrm{C}_{16} \mathrm{H}_{19} \mathrm{ClN}[\mathrm{M}+\mathrm{H}]^{+}$260.1206; found 260.1201. IR (ATR): 3198, 2936, 2800, 2757, 1487, 1452, 1335, 1272, 1144, 1120, 1090, 1068, 971, 836, 797, 756, 716, 695, 586, 557 $\mathrm{cm}^{-1}$. HPLC purity, $98.6 \%\left(t_{\mathrm{R}}=9.78 \mathrm{~min}\right)$.

(E)-4-(4-Chlorostyryl)-1-(prop-2-yn-1-yl)piperidine (80). Synthesized from $41(0.165 \mathrm{~g}, 0.513 \mathrm{mmol}, 1.0$ equiv) via general procedures D and E. Column chromatography, EtOAc/n-hex $=1 / 2$ (v/v). Yield: $45 \%(87 \mathrm{mg})$; white crystals, $\mathrm{mp} 83-85{ }^{\circ} \mathrm{C} .{ }^{1} \mathrm{H}$ NMR $\left(400 \mathrm{MHz}, \mathrm{CDCl}_{3}\right): \delta 1.49-1.59(\mathrm{~m}, 2 \mathrm{H}), 1.76-1.82(\mathrm{~m}, 2 \mathrm{H})$, $2.06-2.16(\mathrm{~m}, 1 \mathrm{H}), 2.23-2.29(\mathrm{~m}, 2 \mathrm{H}), 2.25(\mathrm{t}, J=2.4 \mathrm{~Hz}, 1 \mathrm{H})$, $2.92(\mathrm{td}, J=11.1,2.4 \mathrm{~Hz}, 2 \mathrm{H}), 3.31(\mathrm{~d}, J=2.5 \mathrm{~Hz}, 2 \mathrm{H}), 6.13(\mathrm{dd}, J=$ 16.0, $7.0 \mathrm{~Hz}, 1 \mathrm{H}), 6.31(\mathrm{dd}, J=16.0,1.1 \mathrm{~Hz}, 1 \mathrm{H}), 7.22-7.27(\mathrm{~m}$, $4 \mathrm{H}) .{ }^{13} \mathrm{C}$ NMR $\left(100 \mathrm{MHz}, \mathrm{CDCl}_{3}\right): \delta 31.89,38.77,47.18,52.15$, 72.95, 79.00, 127.00, 127.13, 128.51, 132.39, 135.55, 136.04. HRMS (ESI+): $m / z$ calcd for $\mathrm{C}_{16} \mathrm{H}_{19} \mathrm{ClN}[\mathrm{M}+\mathrm{H}]^{+}$260.1206; found 260.1207. IR (ATR): 3154, 2931, 2916, 2797, 1489, 1441, 1422, 1329, 1313, 1135, 1089, 1010, 971, 907, 850, 801, 722, 594, 519 $\mathrm{cm}^{-1}$. HPLC purity, $99.6 \%\left(t_{\mathrm{R}}=9.81 \mathrm{~min}\right)$.

(E)-4-(4-Bromostyryl)-1-(prop-2-yn-1-yl)piperidine (81). Synthesized from $43(0.36 \mathrm{~g}, 0.98 \mathrm{mmol}, 1.0$ equiv) via general procedures D and E. Column chromatography, EtOAc/n-hex $=1 / 2$ (v/v). Yield: $34 \%\left(102 \mathrm{mg}\right.$ ); white crystals, mp $103-106{ }^{\circ} \mathrm{C} .{ }^{1} \mathrm{H}$ NMR (400 MHz, $\left.\mathrm{CDCl}_{3}\right): \delta 1.50-1.60(\mathrm{~m}, 2 \mathrm{H}), 1.77-1.83(\mathrm{~m}, 2 \mathrm{H})$, $2.08-2.17(\mathrm{~m}, 1 \mathrm{H}), 2.24-2.30(\mathrm{~m}, 3 \mathrm{H}), 2.91-2.95(\mathrm{~m}, 2 \mathrm{H}), 3.32(\mathrm{~d}$, $J=2.2 \mathrm{~Hz}, 2 \mathrm{H}), 6.15(\mathrm{dd}, J=16.0,6.9 \mathrm{~Hz}, 1 \mathrm{H}), 6.31(\mathrm{~d}, J=16.2 \mathrm{~Hz}$, $1 \mathrm{H}), 7.19-7.22(\mathrm{~m}, 2 \mathrm{H}), 7.39-7.42(\mathrm{~m}, 2 \mathrm{H}) .{ }^{13} \mathrm{C}$ NMR (100 MHz, $\left.\mathrm{CDCl}_{3}\right): \delta 31.93,38.85,47.25,52.22,72.96,79.06,120.59,127.15$, 127.56, 131.53, 135.78, 136.59. HRMS (ESI+): $\mathrm{m} / \mathrm{z}$ calcd for $\mathrm{C}_{16} \mathrm{H}_{19} \mathrm{NBr}[\mathrm{M}+\mathrm{H}]^{+}$304.0701; found 304.0706. IR (ATR): 3150, $2929,2850,2798,2745,1485,1466,1423,1328,1310,1135,1117$, $1098,1069,1007,970,906,848,822,798,754,715,579,516 \mathrm{~cm}^{-1}$. HPLC purity, $100 \%\left(t_{\mathrm{R}}=10.00 \mathrm{~min}\right)$.

(E)-4-(4-Methoxystyryl)-1-(prop-2-yn-1-yl)piperidine (82). Synthesized from a mixture of $\mathbf{4 4}$ and $45(0.810 \mathrm{~g}, 2.552 \mathrm{mmol}, 1.0$ equiv) via general procedures $\mathrm{D}$ and $\mathrm{E}$. Column chromatography EtOAc/n-hex $=1 / 1(\mathrm{v} / \mathrm{v})$, yielding only trans isomer 82 . Yield: $32 \%$ $(192 \mathrm{mg})$; white crystals, mp 59-61 ${ }^{\circ} \mathrm{C} .{ }^{1} \mathrm{H}$ NMR $(400 \mathrm{MHz}$, $\left.\mathrm{CDCl}_{3}\right): \delta 1.50-1.60(\mathrm{~m}, 2 \mathrm{H}), 1.76-1.82(\mathrm{~m}, 2 \mathrm{H}), 2.06-2.15(\mathrm{~m}$, $1 \mathrm{H}), 2.23-2.30(\mathrm{~m}, 2 \mathrm{H}), 2.25(\mathrm{t}, J=2.4 \mathrm{~Hz}, 1 \mathrm{H}), 2.90-2.95(\mathrm{~m}$, $2 \mathrm{H}), 3.32(\mathrm{~d}, J=2.4 \mathrm{~Hz}, 2 \mathrm{H}), 3.79(\mathrm{~s}, 3 \mathrm{H}), 6.02(\mathrm{dd}, J=15.9,7.0 \mathrm{~Hz}$, $1 \mathrm{H}), 6.32(\mathrm{~d}, J=15.9 \mathrm{~Hz}, 1 \mathrm{H}), 6.81-6.85(\mathrm{~m}, 2 \mathrm{H}), 7.26-7.30(\mathrm{~m}$, 2H). ${ }^{13} \mathrm{C}$ NMR (100 MHz, $\left.\mathrm{CDCl}_{3}\right): \delta 32.13,38.77,47.23,52.28$, 55.23, 72.90, 79.11, 113.85, 127.02, 127.49, 130.39, 132.77, 158.69 . HRMS (ESI+): $m / z$ calcd for $\mathrm{C}_{17} \mathrm{H}_{22} \mathrm{NO}[\mathrm{M}+\mathrm{H}]^{+} 256.1701$; found 256.1706. IR (ATR): 3270, 2940, 2907, 2825, 1604, 1509, 1467, 1313, 1241, 1176, 1128, 1029, 968, 959, 906, 854, 831, 801, 769, 719, $645,622,529 \mathrm{~cm}^{-1}$. HPLC purity, $97.7 \%\left(t_{\mathrm{R}}=8.92 \mathrm{~min}\right)$.

(Z)-1-(Prop-2-yn-1-yl)-4-(4-(trifluoromethyl)styryl)piperidine (83). Synthesized from $46(0.075 \mathrm{~g}, 0.211 \mathrm{mmol}, 1.0$ equiv) via general procedures $\mathrm{D}$ and $\mathrm{E}$. Column chromatography, EtOAc/n-hex $=2 / 1(\mathrm{v} / \mathrm{v})$. Yield: $81 \%(45 \mathrm{mg})$; pale yellow oil. ${ }^{1} \mathrm{H}$ NMR (400 MHz, $\left.\mathrm{CDCl}_{3}\right): \delta 1.51-1.61(\mathrm{~m}, 2 \mathrm{H}), 1.70-1.74(\mathrm{~m}, 2 \mathrm{H})$, $2.19-2.25(\mathrm{~m}, 2 \mathrm{H}), 2.24(\mathrm{t}, J=2.5 \mathrm{~Hz}, 1 \mathrm{H}), 2.45-2.55(\mathrm{~m}, 1 \mathrm{H})$, $2.87-2.91(\mathrm{~m}, 2 \mathrm{H}), 3.30(\mathrm{~d}, J=2.5 \mathrm{~Hz}, 2 \mathrm{H}), 5.60(\mathrm{dd}, J=11.7,10.2$ $\mathrm{Hz}, 1 \mathrm{H}), 6.39(\mathrm{~d}, J=11.7 \mathrm{~Hz}, 1 \mathrm{H}), 7.33(\mathrm{~d}, J=8.6 \mathrm{~Hz}, 2 \mathrm{H}), 7.59(\mathrm{~d}$, $J=8.2 \mathrm{~Hz}, 2 \mathrm{H}) .{ }^{13} \mathrm{C} \mathrm{NMR}\left(100 \mathrm{MHz}, \mathrm{CDCl}_{3}\right): \delta 32.18,34.55,47.24$, $51.78,73.05,78.92,124.19\left(\mathrm{q}, J_{\mathrm{C}, \mathrm{F}}=271.8 \mathrm{~Hz}\right), 125.17\left(\mathrm{q}, J_{\mathrm{C}, \mathrm{F}}=3.9\right.$ $\mathrm{Hz}), 126.89,128.58\left(\mathrm{t}, J_{\mathrm{C}, \mathrm{F}}=32.3 \mathrm{~Hz}\right), 128.67,139.22,141.18\left(\mathrm{q}, J_{\mathrm{C}, \mathrm{F}}\right.$ $=1.4 \mathrm{~Hz}$ ). HRMS (ESI+): $\mathrm{m} / z$ calcd for $\mathrm{C}_{17} \mathrm{H}_{19} \mathrm{~F}_{3} \mathrm{~N}[\mathrm{M}+\mathrm{H}]^{+}$ 294.1470; found 294.1469. IR (ATR): 3305, 2933, 2805, 1615, 1331, $1167,1129,1068,1017,973,851,634,603 \mathrm{~cm}^{-1}$. HPLC purity, $100 \%$ $\left(t_{\mathrm{R}}=10.21 \mathrm{~min}\right)$.
(E)-1-(Prop-2-yn-1-yl)-4-(4-(trifluoromethyl) styryl)piperidine (84). Synthesized from $47(0.580 \mathrm{~g}, 1.632 \mathrm{mmol}, 1.0$ equiv) via general procedures $\mathrm{D}$ and $\mathrm{E}$. Column chromatography, EtOAc/n-hex $=2 / 1(\mathrm{v} / \mathrm{v})$. Yield: $85 \%(376 \mathrm{mg})$; white crystals, $\mathrm{mp}$ $72-74{ }^{\circ} \mathrm{C} .{ }^{1} \mathrm{H}$ NMR $\left(400 \mathrm{MHz}, \mathrm{CDCl}_{3}\right): \delta 1.52-1.62(\mathrm{~m}, 2 \mathrm{H})$, $1.80-1.85(\mathrm{~m}, 2 \mathrm{H}), 2.12-2.20(\mathrm{~m}, 1 \mathrm{H}), 2.26(\mathrm{t}, J=2.4 \mathrm{~Hz}, 1 \mathrm{H})$, $2.25-2.32(\mathrm{~m}, 2 \mathrm{H}), 2.92-2.96(\mathrm{~m}, 2 \mathrm{H}), 3.33(\mathrm{~d}, J=2.5 \mathrm{~Hz}, 2 \mathrm{H})$, $6.27(\mathrm{dd}, J=16.0,6.9 \mathrm{~Hz}, 1 \mathrm{H}), 6.41(\mathrm{~d}, J=16.0 \mathrm{~Hz}, 1 \mathrm{H}), 7.43(\mathrm{~d}, J=$ $8.4 \mathrm{~Hz}, 2 \mathrm{H}), 7.54(\mathrm{~d}, J=8.2 \mathrm{~Hz}, 2 \mathrm{H}) .{ }^{13} \mathrm{C} \mathrm{NMR}\left(100 \mathrm{MHz}, \mathrm{CDCl}_{3}\right)$ : $\delta 31.78,38.84,47.17,52.11,72.97,78.95,124.20\left(\mathrm{q}, J_{\mathrm{C}, \mathrm{F}}=271.8 \mathrm{~Hz}\right)$, $125.34\left(\mathrm{q}, J_{\mathrm{C}, \mathrm{F}}=3.9 \mathrm{~Hz}\right), 126.07,127.02,128.69\left(\mathrm{q}, J_{\mathrm{C}, \mathrm{F}}=32.4 \mathrm{~Hz}\right)$, $137.62,141.07\left(\mathrm{q}, J_{\mathrm{C}, \mathrm{F}}=1.4 \mathrm{~Hz}\right)$. HRMS $(\mathrm{ESI}+): \mathrm{m} / z$ calcd for $\mathrm{C}_{17} \mathrm{H}_{19} \mathrm{~F}_{3} \mathrm{~N}[\mathrm{M}+\mathrm{H}]^{+}$294.1470; found 294.1464. IR (ATR): 3157, 2933, 2917, 2806, 1613, 1312, 1160, 1109, 1066, 1055, 972, 866, 831, 736, 600, 579, $517 \mathrm{~cm}^{-1}$. HPLC purity, 99.9\% $\left(t_{\mathrm{R}}=10.19 \mathrm{~min}\right)$.

(Z)-1-(Prop-2-yn-1-yl)-4-(3-(trifluoromethyl) styryl)piperidine (85). Synthesized from $48(0.05 \mathrm{~g}, 0.14 \mathrm{mmol}, 1.0$ equiv $)$ via general procedures $\mathrm{D}$ and $\mathrm{E}$. Column chromatography, EtOAc/nhex $=1 / 3(\mathrm{v} / \mathrm{v})$. Yield: $27 \%(11 \mathrm{mg})$; yellow oil. ${ }^{1} \mathrm{H}$ NMR $(400 \mathrm{MHz}$, $\left.\mathrm{CDCl}_{3}\right): \delta 1.59-1.77(\mathrm{~m}, 2 \mathrm{H}), 1.75(\mathrm{dd}, J=12.8,2.2 \mathrm{~Hz}, 2 \mathrm{H}), 2.26-$ $2.32(\mathrm{~m}, 3 \mathrm{H}), 2.44-2.54(\mathrm{~m}, 1 \mathrm{H}), 2.92-2.98(\mathrm{~m}, 2 \mathrm{H}), 3.35(\mathrm{~d}, J=$ $2.4 \mathrm{~Hz}, 2 \mathrm{H}), 5.60(\mathrm{dd}, J=11.6,10.2 \mathrm{~Hz}, 1 \mathrm{H}), 5.41(\mathrm{~d}, J=11.7 \mathrm{~Hz}$, $1 \mathrm{H}), 7.39-7.51(\mathrm{~m}, 4 \mathrm{H}) .{ }^{13} \mathrm{C}$ NMR $\left(100 \mathrm{MHz}, \mathrm{CDCl}_{3}\right): \delta 31.83$, $34.35,47.10,51.69,73.79,78.08,123.37\left(\mathrm{q}, J_{\mathrm{C}, \mathrm{F}}=3.8 \mathrm{~Hz}\right), 124.10(\mathrm{q}$, $\left.J_{\mathrm{C}, \mathrm{F}}=272.3 \mathrm{~Hz}\right), 125.21\left(\mathrm{q}, J_{\mathrm{C}, \mathrm{F}}=3.7 \mathrm{~Hz}\right), 127.08,128.72,130.64(\mathrm{q}$, $\left.J_{\mathrm{C}, \mathrm{F}}=32.2 \mathrm{~Hz}\right), 131.60,138.20,138.45$. HRMS (ESI $): \mathrm{m} / z$ calcd for $\mathrm{C}_{17} \mathrm{H}_{19} \mathrm{NF}_{3}[\mathrm{M}+\mathrm{H}]^{+}$294.1470; found 294.1466. IR (ATR): 3306, 2933, 2850, 2804, 2757, 1688, 1444, 1327, 1162, 1122, 1092, 1072, $972,905,807,703,696,656,628 \mathrm{~cm}^{-1}$. HPLC purity, 95.9\% $\left(t_{\mathrm{R}}=\right.$ $10.13 \mathrm{~min})$.

(E)-1-(Prop-2-yn-1-yl)-4-(3-(trifluoromethyl)styryl)piperidine (86). Synthesized from $49(0.19 \mathrm{~g}, 0.53 \mathrm{mmol}, 1.0$ equiv $)$ via general procedures D and E. Column chromatography, EtOAc/nhex $=1 / 3(\mathrm{v} / \mathrm{v})$. Yield: $70 \%(109 \mathrm{mg})$; green oil. ${ }^{1} \mathrm{H}$ NMR (400 $\left.\mathrm{MHz}, \mathrm{CDCl}_{3}\right): \delta 1.52-1.62(\mathrm{~m}, 2 \mathrm{H}), 1.78-1.84(\mathrm{~m}, 2 \mathrm{H}), 2.11-2.20$ $(\mathrm{m}, 1 \mathrm{H}), 2.26(\mathrm{t}, J=2.4 \mathrm{~Hz}, 1 \mathrm{H}), 2.29(\mathrm{dt}, J=11.8,2.3 \mathrm{~Hz}, 2 \mathrm{H})$, $2.91-2.97(\mathrm{~m}, 2 \mathrm{H}), 3.33(\mathrm{~d}, J=2.4 \mathrm{~Hz}, 2 \mathrm{H}), 6.24(\mathrm{dd}, J=16.0,6.9$ $\mathrm{Hz}, 1 \mathrm{H}), 6.41(\mathrm{~d}, J=16.0 \mathrm{~Hz}, 1 \mathrm{H}), 7.38-7.45(\mathrm{~m}, 2 \mathrm{H}), 7.51(\mathrm{~d}, J=$ $7.5 \mathrm{~Hz}, 1 \mathrm{H}), 7.58(\mathrm{~s}, 1 \mathrm{H}) .{ }^{13} \mathrm{C}$ NMR $\left(100 \mathrm{MHz}, \mathrm{CDCl}_{3}\right): \delta 31.87$, $38.86,47.24,52.18,73.01,79.02,122.64\left(\mathrm{q}, J_{\mathrm{C}, \mathrm{F}}=3.9 \mathrm{~Hz}\right), 123.50(\mathrm{q}$, $\left.J_{\mathrm{C}, \mathrm{F}}=3.9 \mathrm{~Hz}\right), 124.16\left(\mathrm{q}, J_{\mathrm{C}, \mathrm{F}}=272.3 \mathrm{~Hz}\right), 127.03,128.88,129.18$, $130.85\left(\mathrm{q}, J_{\mathrm{C}, \mathrm{F}}=32.1 \mathrm{~Hz}\right), 136.91,138.39$. HRMS (ESI +$): \mathrm{m} / z$ calcd for $\mathrm{C}_{17} \mathrm{H}_{19} \mathrm{NF}_{3}[\mathrm{M}+\mathrm{H}]^{+}$294.1470; found 294.1465. IR (ATR): 3306, 2934, 2849, 2804, 2755, 1444, 1329, 1201, 1162, 1120, 1094, $1071,965,900,792,696,662,628 \mathrm{~cm}^{-1}$. HPLC purity, $99.8 \%\left(t_{\mathrm{R}}=\right.$ $10.16 \mathrm{~min})$.

(Z)-4-(2-(1-(Prop-2-yn-1-yl)piperidin-4-yl)vinyl)benzonitrile (87). Synthesized from $50(0.350 \mathrm{~g}, 1.120 \mathrm{mmol}, 1.0$ equiv) via general procedures $\mathrm{D}$ and $\mathrm{E}$. Column chromatography, EtOAc/ $\mathrm{CH}_{2} \mathrm{Cl}_{2}=3 / 7(\mathrm{v} / \mathrm{v})$. Yield: $50 \%(125 \mathrm{mg})$; white crystals, mp $118-$ $121{ }^{\circ} \mathrm{C} .{ }^{1} \mathrm{H}$ NMR $\left(400 \mathrm{MHz}, \mathrm{CDCl}_{3}\right): \delta 1.51-1.61(\mathrm{~m}, 2 \mathrm{H}), 1.68-$ $1.74(\mathrm{~m}, 2 \mathrm{H}), 2.19-2.25(\mathrm{~m}, 2 \mathrm{H}), 2.24(\mathrm{t}, J=2.4 \mathrm{~Hz}, 1 \mathrm{H}), 2.42-$ $2.50(\mathrm{~m}, 1 \mathrm{H}), 2.86-2.91(\mathrm{~m}, 2 \mathrm{H}), 3.30(\mathrm{~d}, J=2.5 \mathrm{~Hz}, 2 \mathrm{H}), 5.64(\mathrm{dd}$, $J=11.7,10.2 \mathrm{~Hz}, 1 \mathrm{H}), 6.37(\mathrm{~d}, J=11.8 \mathrm{~Hz}, 1 \mathrm{H}), 7.30-7.33(\mathrm{~m}, 2 \mathrm{H})$, 7.61-7.63 (m, 2H). ${ }^{13} \mathrm{C}$ NMR $\left(100 \mathrm{MHz}, \mathrm{CDCl}_{3}\right): \delta 32.01,34.61$, 47.15, 51.64, 73.05, 78.81, 110.05, 118.88, 126.58, 129.00, 132.02, 140.13, 142.21. HRMS (ESI+): $m / z$ calcd for $\mathrm{C}_{17} \mathrm{H}_{19} \mathrm{~N}_{2}[\mathrm{M}+\mathrm{H}]^{+}$ 251.1548; found 251.1550. IR (ATR): 3199, 2930, 2812, 2793, 2771, $2225,1602,1500,1451,1396,1337,1274,1226,1143,1110,970$, $850,729,697,569,528 \mathrm{~cm}^{-1}$. HPLC purity, $98.3 \%\left(t_{\mathrm{R}}=8.39 \mathrm{~min}\right)$.

(E)-4-(2-(1-(Prop-2-yn-1-yl)piperidin-4-yl)vinyl)benzonitrile (88). Synthesized from (51 $(0.300 \mathrm{~g}, 0.960 \mathrm{mmol}, 1.0$ equiv) via general procedures $\mathrm{D}$ and $\mathrm{E}$. Column chromatography, $\mathrm{CH}_{2} \mathrm{Cl}_{2}$ / $\mathrm{MeOH}=50 / 1(\mathrm{v} / \mathrm{v})$. Yield: $54 \%(130 \mathrm{mg})$; white crystals, $\mathrm{mp}$ 59-62 ${ }^{\circ} \mathrm{C} .{ }^{1} \mathrm{H}$ NMR $\left(400 \mathrm{MHz}, \mathrm{CDCl}_{3}\right): \delta 1.47-1.58(\mathrm{~m}, 2 \mathrm{H}), 1.74-1.80$ (m, $2 \mathrm{H}), 2.09-2.18(\mathrm{~m}, 1 \mathrm{H}), 2.21-2.27(\mathrm{~m}, 2 \mathrm{H}), 2.23(\mathrm{t}, J=2.4 \mathrm{~Hz}$, $1 \mathrm{H}), 2.87-2.92(\mathrm{~m}, 2 \mathrm{H}), 3.28(\mathrm{~d}, J=2.5 \mathrm{~Hz}, 2 \mathrm{H}), 6.27(\mathrm{dd}, J=16.0$, $6.5 \mathrm{~Hz}, 1 \mathrm{H}), 6.35(\mathrm{~d}, J=16.1 \mathrm{~Hz}, 1 \mathrm{H}), 7.36-7.39(\mathrm{~m}, 2 \mathrm{H}), 7.51-$ $7.54(\mathrm{~m}, 2 \mathrm{H}) .{ }^{13} \mathrm{C}$ NMR $\left(100 \mathrm{MHz}, \mathrm{CDCl}_{3}\right): \delta 31.58,38.79,47.06$, 51.95, 72.96, 78.83, 109.93, 118.93, 126.35, 126.77, 132.16, 138.94, 
141.99. HRMS (ESI+): $m / z$ calcd for $\mathrm{C}_{17} \mathrm{H}_{19} \mathrm{~N}_{2}[\mathrm{M}+\mathrm{H}]^{+} 251.1548$; found 251.1549. IR (ATR): 3284, 2941, 2916, 2802, 2224, 1646, $1602,1503,1423,1382,1338,1315,1223,1138,1104,984,970,900$, $855,831,762,692,630,551 \mathrm{~cm}^{-1}$. HPLC purity, $99.3 \%\left(t_{\mathrm{R}}=8.34\right.$ $\min )$.

(Z)-4-(4-(Methylsulfonyl)styryl)-1-(prop-2-yn-1-yl)piperidine (89). Synthesized from $52(0.126 \mathrm{~g}, 0.346 \mathrm{mmol}, 1.0$ equiv) via general procedures $\mathrm{D}$ and $\mathrm{E}$. Column chromatography, EtOAc/n-hex $=2 / 1(\mathrm{v} / \mathrm{v})$. Yield: $76 \%(80 \mathrm{mg})$; white crystals, $\mathrm{mp}$ 71-74 ${ }^{\circ} \mathrm{C} .{ }^{1} \mathrm{H}$ NMR $\left(400 \mathrm{MHz}, \mathrm{CDCl}_{3}\right): \delta 1.49-1.60(\mathrm{~m}, 2 \mathrm{H})$, $1.67-1.73(\mathrm{~m}, 2 \mathrm{H}), 2.20(\mathrm{dt}, J=11.7,2.5 \mathrm{~Hz}, 2 \mathrm{H}), 2.23(\mathrm{t}, J=2.4$ $\mathrm{Hz}, 1 \mathrm{H}), 2.41-2.51(\mathrm{~m}, 1 \mathrm{H}), 2.86(\mathrm{td}, J=8.9,2.7 \mathrm{~Hz}, 2 \mathrm{H}), 3.05(\mathrm{~s}$, $3 \mathrm{H}), 3.28(\mathrm{~d}, J=2.5 \mathrm{~Hz}, 2 \mathrm{H}), 5.64(\mathrm{dd}, J=11.7,10.3 \mathrm{~Hz}, 1 \mathrm{H}), 6.39$ $(\mathrm{d}, J=11.7 \mathrm{~Hz}, 1 \mathrm{H}), 7.37-7.40(\mathrm{~m}, 2 \mathrm{H}), 7.86-7.90(\mathrm{~m}, 2 \mathrm{H}) .{ }^{13} \mathrm{C}$ NMR $\left(100 \mathrm{MHz}, \mathrm{CDCl}_{3}\right): \delta 32.03,34.60,44.46,47.16,51.64,73.08$, 78.82, 126.42, 127.32, 129.17, 138.28, 140.29, 143.22. HRMS (ESI+): $\mathrm{m} / \mathrm{z}$ calcd for $\mathrm{C}_{17} \mathrm{H}_{22} \mathrm{NO}_{2} \mathrm{~S}[\mathrm{M}+\mathrm{H}]^{+} 304.1371$; found 304.1370 . IR (ATR): 3273, 2937, 2799, 2757, 1640, 1593, 1463, 1415, 1296, 1141, $1078,955,848,774,723,679,615,593,525 \mathrm{~cm}^{-1}$. HPLC purity, $98.3 \%\left(t_{\mathrm{R}}=4.60 \mathrm{~min}\right)$.

(E)-4-(4-(Methylsulfonyl)styryl)-1-(prop-2-yn-1-yl)piperidine (90). Synthesized from $53(0.205 \mathrm{~g}, 0.56 \mathrm{mmol}, 1.0$ equiv) via general procedures D and E. Column chromatography, EtOAc/n-hex $=2 / 1$ (v/v). Yield: $85 \%(145 \mathrm{mg})$; white crystals, mp $101-105{ }^{\circ} \mathrm{C} .{ }^{1} \mathrm{H}$ NMR $\left(400 \mathrm{MHz}, \mathrm{CDCl}_{3}\right): \delta 1.52-1.62(\mathrm{~m}, 2 \mathrm{H}), 1.80-1.85(\mathrm{~m}, 2 \mathrm{H})$, 2.14-2.23 (m, 1H), 2.25-2.32 (m, 3H), 2.92-2.97 (m, 2H), $3.04(\mathrm{~s}$, $3 \mathrm{H}), 3.33(\mathrm{~d}, J=2.2 \mathrm{~Hz}, 2 \mathrm{H}), 6.34(\mathrm{dd}, J=16.0,6.6 \mathrm{~Hz}, 1 \mathrm{H}), 6.43$ $(\mathrm{d}, J=16.1 \mathrm{~Hz}, 1 \mathrm{H}), 7.51(\mathrm{~d}, J=8.1 \mathrm{~Hz}, 2 \mathrm{H}), 7.85(\mathrm{~d}, J=8.0 \mathrm{~Hz}$, $2 \mathrm{H}) .{ }^{13} \mathrm{C}$ NMR $\left(100 \mathrm{MHz}, \mathrm{CDCl}_{3}\right): \delta 31.73,38.98,44.60,47.22$, $52.11,73.05,78.94,126.66,126.74,127.68,138.37,139.35,143.16$. HRMS (ESI+): $m / z$ calcd for $\mathrm{C}_{17} \mathrm{H}_{22} \mathrm{NO}_{2} \mathrm{~S}[\mathrm{M}+\mathrm{H}]^{+} 304.1371$; found 304.1372. IR (ATR): 3282, 2927, 2797, 2750, 1647, 1595, $1466,1404,1303,1146,1091,960,858,767,705,684,649,595,544$, $526 \mathrm{~cm}^{-1}$. HPLC purity, $95.1 \%\left(t_{\mathrm{R}}=5.06 \mathrm{~min}\right)$.

(Z)-4-(4-Cyclopropylstyryl)-1-(prop-2-yn-1-yl)piperidine (91). Synthesized from 54 (0.080 g, $0.244 \mathrm{mmol}, 1.0$ equiv) via general procedures D and E. Column chromatography, EtOAc/n-hex $=1 / 2(\mathrm{v} / \mathrm{v})$. Yield: $20 \%(16 \mathrm{mg})$; colorless oil. ${ }^{1} \mathrm{H}$ NMR $(400 \mathrm{MHz}$, $\left.\mathrm{CDCl}_{3}\right): \delta 0.68-0.72(\mathrm{~m}, 2 \mathrm{H}), 0.94-0.99(\mathrm{~m}, 2 \mathrm{H}), 1.49-1.59(\mathrm{~m}$, $2 \mathrm{H}), 1.71-1.77(\mathrm{~m}, 2 \mathrm{H}), 1.86-1.92(\mathrm{~m}, 1 \mathrm{H}), 2.20-2.26(\mathrm{~m}, 3 \mathrm{H})$, $2.52-2.62(\mathrm{~m}, 1 \mathrm{H}), 2.86-2.91(\mathrm{~m}, 2 \mathrm{H}), 3.30(\mathrm{~d}, J=2.5 \mathrm{~Hz}, 2 \mathrm{H})$, $5.43(\mathrm{dd}, J=11.6,10.0 \mathrm{~Hz}, 1 \mathrm{H}), 6.33(\mathrm{~d}, J=11.6 \mathrm{~Hz}, 1 \mathrm{H}), 7.02-7.06$ $(\mathrm{m}, 2 \mathrm{H}), 7.12-7.16(\mathrm{~m}, 2 \mathrm{H}) .{ }^{13} \mathrm{C}$ NMR $\left(100 \mathrm{MHz}, \mathrm{CDCl}_{3}\right): \delta 9.31$, 15.16, 32.35, 34.45, 47.28, 51.95, 72.96, 79.08, 125.44, 127.88, 128.47, $134.75,136.53,142.48$. HRMS (ESI +$): m / z$ calcd for $\mathrm{C}_{19} \mathrm{H}_{24} \mathrm{~N}[\mathrm{M}+$ $\mathrm{H}]^{+}$266.1909; found 266.1905. IR (ATR): 3355, 2973, 2916, 2849, 1739, 1654, 1468, 1373, 1239, 1086, 1045, 879, $719 \mathrm{~cm}^{-1}$. HPLC purity, $95.9 \%\left(t_{\mathrm{R}}=10.27 \mathrm{~min}\right)$.

(E)-4-(4-Cyclopropylstyryl)-1-(prop-2-yn-1-yl)piperidine (92). Synthesized from $55(0.200 \mathrm{~g}, 0.611 \mathrm{mmol}, 1.0$ equiv) via general procedures $\mathrm{D}$ and E. Column chromatography, EtOAc/n-hex $=1 / 2(\mathrm{v} / \mathrm{v})$. Yield: $40 \%(65 \mathrm{mg})$; pale yellow crystals, $\mathrm{mp} 66-68{ }^{\circ} \mathrm{C}$. ${ }^{1} \mathrm{H}$ NMR $\left(400 \mathrm{MHz}, \mathrm{CDCl}_{3}\right): \delta 0.66-0.70(\mathrm{~m}, 2 \mathrm{H}), 0.92-0.97(\mathrm{~m}$, $2 \mathrm{H}), 1.50-1.61(\mathrm{dt}, 2 \mathrm{H}), 1.77-1.83(\mathrm{~m}, 2 \mathrm{H}), 1.85-1.90(\mathrm{~m}, 1 \mathrm{H})$, $2.07-2.17(\mathrm{~m}, 1 \mathrm{H}), 2.26(\mathrm{t}, J=2.4 \mathrm{~Hz}, 1 \mathrm{H}), 2.27(\mathrm{dt}, J=11.7,2.5$ $\mathrm{Hz}, 2 \mathrm{H}), 2.90-2.95(\mathrm{~m}, 2 \mathrm{H}), 3.32(\mathrm{~d}, J=2.4 \mathrm{~Hz}, 2 \mathrm{H}), 6.10(\mathrm{dd}, J=$ $15.9,7.0 \mathrm{~Hz}, 1 \mathrm{H}), 6.34(\mathrm{~d}, J=15.9 \mathrm{~Hz}, 1 \mathrm{H}), 6.98-7.01(\mathrm{~m}, 2 \mathrm{H})$, 7.23-7.26 (m, 2H). ${ }^{13} \mathrm{C}$ NMR (100 MHz, $\left.\mathrm{CDCl}_{3}\right): \delta 9.17,15.12$, $32.04,38.75,47.20,52.23,72.91,79.06,125.66,125.84,127.90$, $133.77,134.82,142.79$. HRMS (ESI+): $m / z$ calcd for $\mathrm{C}_{19} \mathrm{H}_{24} \mathrm{~N}[\mathrm{M}+$ $\mathrm{H}]^{+}$266.1909; found 266.1908. IR (ATR): 3007, 2932, 2919, 2854, $2805,2748,1607,1514,1424,1385,1312,1135,1103,1041,1022$, $972,891,851,804,684,665,644,630,546 \mathrm{~cm}^{-1}$. HPLC purity, $98.1 \%\left(t_{\mathrm{R}}=10.27 \mathrm{~min}\right)$.

4-Phenethyl-1-(prop-2-yn-1-yl)piperidine (93). Synthesized from $56(1.040 \mathrm{~g}, 3.593 \mathrm{mmol}, 1.0$ equiv) via general procedures $\mathrm{D}$ and E. Column chromatographym EtOAc/n-hex $=1 / 2(\mathrm{v} / \mathrm{v})$. Yield: $56 \%(202 \mathrm{mg})$; yellow oil. ${ }^{1} \mathrm{H}$ NMR $\left(400 \mathrm{MHz}, \mathrm{CDCl}_{3}\right): \delta 1.24-1.39$ $(\mathrm{m}, 3 \mathrm{H}), 1.56-1.62(\mathrm{~m}, 2 \mathrm{H}), 1.75-1.81(\mathrm{~m}, 2 \mathrm{H}), 2.15-2.22(\mathrm{~m}$, $2 \mathrm{H}), 2.24(\mathrm{t}, J=2.5 \mathrm{~Hz}, 1 \mathrm{H}), 2.62-2.66(\mathrm{~m}, 2 \mathrm{H}), 2.87-2.92(\mathrm{~m}$,
$2 \mathrm{H}), 3.30(\mathrm{~d}, J=2.5 \mathrm{~Hz}, 2 \mathrm{H}), 7.16-7.21(\mathrm{~m}, 3 \mathrm{H}), 7.26-7.31(\mathrm{~m}$, $2 \mathrm{H}) .{ }^{13} \mathrm{C}$ NMR $\left(100 \mathrm{MHz}, \mathrm{CDCl}_{3}\right): \delta 32.05,32.89,34.58,38.15$, 47.03, 52.34, 72.74, 79.02, 125.44, $128.10(4 \times \mathrm{C}), 142.43$. HRMS (ESI+): $m / z$ calcd for $\mathrm{C}_{16} \mathrm{H}_{22} \mathrm{~N}[\mathrm{M}+\mathrm{H}]^{+} 228.1752$; found 228.1755 . IR (ATR): 3297, 2935, 2908, 2801, 1496, 1337, 1313, 750, 700, 641 $\mathrm{cm}^{-1}$. HPLC purity, $99.9 \%\left(t_{\mathrm{R}}=8.86 \mathrm{~min}\right)$.

4-(3-Fluorophenethyl)-1-(prop-2-yn-1-yl)piperidine (94). Synthesized from $57(0.320 \mathrm{~g}, 1.04 \mathrm{mmol}, 1.0$ equiv $)$ via general procedures $\mathrm{D}$ and $\mathrm{E}$. Column chromatography EtOAc/n-hex $=1 / 2$ (v/v). Yield: $18 \%(46 \mathrm{mg})$; yellow oil. ${ }^{1} \mathrm{H}$ NMR $\left(400 \mathrm{MHz}, \mathrm{CDCl}_{3}\right)$ : $\delta 1.21-1.37(\mathrm{~m}, 3 \mathrm{H}), 1.52-1.58(\mathrm{~m}, 2 \mathrm{H}), 1.73-1.78(\mathrm{~m}, 2 \mathrm{H}), 2.14-$ $2.20(\mathrm{~m}, 2 \mathrm{H}), 2.23(\mathrm{t}, J=2.4 \mathrm{~Hz}, 1 \mathrm{H}), 2.59-2.63(\mathrm{~m}, 2 \mathrm{H}), 2.86-$ $2.91(\mathrm{~m}, 2 \mathrm{H}), 3.29(\mathrm{~d}, J=2.4 \mathrm{~Hz}, 2 \mathrm{H}), 6.83-6.89(\mathrm{~m}, 2 \mathrm{H}), 6.92-$ $6.95(\mathrm{~m}, 1 \mathrm{H}), 7.18-7.24(\mathrm{~m}, 1 \mathrm{H}) .{ }^{13} \mathrm{C} \mathrm{NMR}\left(100 \mathrm{MHz}, \mathrm{CDCl}_{3}\right): \delta$ 32.10, 32.76, $32.7834 .64,37.90,47.14,52.45,72.93,79.04,112.46$ (d, $\left.J_{\mathrm{C}, \mathrm{F}}=21.9 \mathrm{~Hz}\right), 115.04\left(\mathrm{~d}, J_{\mathrm{C}, \mathrm{F}}=20.5 \mathrm{~Hz}\right), 123.90\left(\mathrm{~d}, J_{\mathrm{C}, \mathrm{F}}=2.2 \mathrm{~Hz}\right)$, $129.60\left(\mathrm{~d}, J_{\mathrm{C}, \mathrm{F}}=8.7 \mathrm{~Hz}\right), 145.18\left(\mathrm{~d}, J_{\mathrm{C}, \mathrm{F}}=7.2 \mathrm{~Hz}\right), 162.83\left(\mathrm{~d}, J_{\mathrm{C}, \mathrm{F}}=\right.$ $245.0 \mathrm{~Hz}$ ). HRMS (ESI +$): m / z$ calcd for $\mathrm{C}_{16} \mathrm{H}_{21} \mathrm{FN}[\mathrm{M}+\mathrm{H}]^{+}$ 246.1658; found 246.1659. IR (ATR): 3305, 2919, 2849, 2803, 2755, $1616,1588,1488,1466,1446,1387,1367,1337,1312,1251,1183$, $1139,1125,1105,1085,1021,995,976,959,934,888,866,782,741$, $719,691,629 \mathrm{~cm}^{-1}$. HPLC purity, $97.6 \%\left(t_{\mathrm{R}}=9.26 \mathrm{~min}\right)$.

4-(2-Fluorophenethyl)-1-(prop-2-yn-1-yl)piperidine (95). Synthesized from $58(0.220 \mathrm{~g}, 0.716 \mathrm{mmol}, 1.0$ equiv $)$ via general procedures D and E. Column chromatography, EtOAc/n-hex $=1 / 2$ (v/v). Yield: $8 \%(14 \mathrm{mg})$; yellow oil. ${ }^{1} \mathrm{H}$ NMR $\left(400 \mathrm{MHz} \mathrm{CDCl}_{3}\right): \delta$ $1.25-1.37(\mathrm{~m}, 3 \mathrm{H}), 1.53-1.58(\mathrm{~m}, 2 \mathrm{H}), 1.77-1.80(\mathrm{~m}, 2 \mathrm{H}), 2.15-$ $2.20(\mathrm{~m}, 2 \mathrm{H}), 2.23(\mathrm{t}, J=2.4 \mathrm{~Hz}, 1 \mathrm{H}), 2.63-2.67(\mathrm{~m}, 2 \mathrm{H}), 2.87-$ $2.90(\mathrm{~m}, 2 \mathrm{H}), 3.30(\mathrm{~d}, J=2.4 \mathrm{~Hz}, 2 \mathrm{H}), 6.97-7.02(\mathrm{~m}, 1 \mathrm{H}), 7.03-$ $7.07(\mathrm{~m}, 1 \mathrm{H}), 7.13-7.20(\mathrm{~m}, 2 \mathrm{H}) .{ }^{13} \mathrm{C}$ NMR $\left(100 \mathrm{MHz}, \mathrm{CDCl}_{3}\right): \delta$ $26.17,32.12,34.85,36.88,47.20,52.53,72.89,79.15,115.15\left(\mathrm{~d}, J_{\mathrm{C}, \mathrm{F}}=\right.$ $22.5 \mathrm{~Hz}), 123.88\left(\mathrm{~d}, J_{\mathrm{CF}}=3.4 \mathrm{~Hz}\right), 127.32\left(\mathrm{~d}, J_{\mathrm{C} F}=8.0 \mathrm{~Hz}\right), 129.41$ $\left(\mathrm{d}, J_{\mathrm{C}, \mathrm{F}}=16.1 \mathrm{~Hz}\right), 130.41\left(\mathrm{~d}, J_{\mathrm{C}, \mathrm{F}}=5.3 \mathrm{~Hz}\right), 161.08\left(\mathrm{~d}, J_{\mathrm{C}, \mathrm{F}}=244.5\right.$ $\mathrm{Hz}$ ). HRMS (ESI+): $m / z$ calcd for $\mathrm{C}_{16} \mathrm{H}_{21} \mathrm{FN}[\mathrm{M}+\mathrm{H}]^{+} 246.1658$; found 246.1657. IR (ATR): 3383, 2975, 2931, 1691, 1638, 1492, $1453,1423,1366,1324,1277,1228,1161,1127,1086,1033,966$, $863,804,757 \mathrm{~cm}^{-1}$. HPLC purity, $95.1 \%\left(t_{\mathrm{R}}=9.20 \mathrm{~min}\right)$.

4-(4-Methylphenethyl)-1-(prop-2-yn-1-yl)piperidine (96). Synthesized from $59(0.28 \mathrm{~g}, 0.92 \mathrm{mmol}, 1.0$ equiv) via general procedures D and E. Column chromatography, EtOAc/n-hex $=1 / 3$ (v/v). Yield: $36 \%(79 \mathrm{mg})$; yellow oil. ${ }^{1} \mathrm{H}$ NMR (400 $\left.\mathrm{MHz}, \mathrm{CDCl}_{3}\right)$ : $\delta 1.21-1.36(\mathrm{~m}, 3 \mathrm{H}), 1.52-1.57(\mathrm{~m}, 2 \mathrm{H}), 1.75-1.78(\mathrm{~m}, 2 \mathrm{H}), 2.14-$ $2.20(\mathrm{~m}, 2 \mathrm{H}), 2.23(\mathrm{t}, J=2.4 \mathrm{~Hz}, 1 \mathrm{H}), 2.31(\mathrm{~s}, 3 \mathrm{H}), 2.56-2.60(\mathrm{~m}$, $2 \mathrm{H}), 2.86-2.89(\mathrm{~m}, 2 \mathrm{H}), 3.29(\mathrm{~d}, J=2.4 \mathrm{~Hz}, 2 \mathrm{H}), 7.05-7.10(\mathrm{~m}$, $4 \mathrm{H}) .{ }^{13} \mathrm{C}$ NMR $\left(100 \mathrm{MHz}, \mathrm{CDCl}_{3}\right): \delta 20.97,32.21,32.57,34.68$, $38.43,47.21,52.55,72.83,79.05,128.17,128.97,135.05,139.58$. HRMS (ESI +$): m / z$ calcd for $\mathrm{C}_{17} \mathrm{H}_{24} \mathrm{~N}[\mathrm{M}+\mathrm{H}]^{+} 242.1909$; found 242.1904. IR (ATR): 3183, 2932, 2917, 2847, 2798, 2752, 1515, 1451, 1333, 1293, 1270, 1144, 1103, 1080, 974, 850, 800, 784, 739, $559,506 \mathrm{~cm}^{-1}$. HPLC purity, $97.4 \%\left(t_{\mathrm{R}}=9.75 \mathrm{~min}\right)$.

4-(4-Isopropylphenethyl)-1-(prop-2-yn-1-yl)piperidine (97). Synthesized from $60(0.290 \mathrm{~g}, 0.875 \mathrm{mmol}, 1.0$ equiv $)$ via general procedures D and E. Column chromatography, EtOAc/n-hex $=1 / 2$ (v/v). Yield: $55 \%(112 \mathrm{mg})$; yellow oil. ${ }^{1} \mathrm{H}$ NMR $\left(400 \mathrm{MHz}, \mathrm{CDCl}_{3}\right)$ : $\delta 1.28(\mathrm{~d}, J=7.0 \mathrm{~Hz}, 6 \mathrm{H}), 1.32-1.39(\mathrm{~m}, 3 \mathrm{H}), 1.58-1.63(\mathrm{~m}, 2 \mathrm{H})$, $1.79-1.84(\mathrm{~m}, 2 \mathrm{H}), 2.19-2.25(\mathrm{~m}, 2 \mathrm{H}), 2.26(\mathrm{t}, J=2.4 \mathrm{~Hz}, 1 \mathrm{H})$, $2.62-2.66(\mathrm{~m}, 2 \mathrm{H}), 2.88-2.95(\mathrm{~m}, 3 \mathrm{H}), 3.33(\mathrm{~d}, J=2.5 \mathrm{~Hz}, 2 \mathrm{H})$, 7.13-7.16 (m, 2H), 7.17-7.20 (m, 2H). ${ }^{13} \mathrm{C}$ NMR $(100 \mathrm{MHz}$, $\left.\mathrm{CDCl}_{3}\right): \delta 24.02,32.18,32.56,33.59,34.76,38.34,47.16,52.50$, $72.78,79.17,126.24,128.10,139.90,146.03$. HRMS (ESI+): $\mathrm{m} / z$ calcd for $\mathrm{C}_{19} \mathrm{H}_{28} \mathrm{~N}[\mathrm{M}+\mathrm{H}]^{+} 270.2222$; found 270.2226. IR (ATR): 3282, 2958, 2933, 2908, 2801, 2753, 1512, 1128, 1105, 976, 817, 677, $654,641 \mathrm{~cm}^{-1}$. HPLC purity, $99.8 \%\left(t_{\mathrm{R}}=10.99 \mathrm{~min}\right)$.

4-(4-Chlorophenethyl)-1-(prop-2-yn-1-yl)piperidine (98). Synthesized from 61 (0.195 g, $0.602 \mathrm{mmol}, 1.0$ equiv) via general procedures D and E. Column chromatography, EtOAc/n-hex $=1 / 2$ (v/v). Yield: $62 \%(85 \mathrm{mg})$; white crystals, mp $37-39{ }^{\circ} \mathrm{C} .{ }^{1} \mathrm{H}$ NMR $\left(400 \mathrm{MHz}, \mathrm{CDCl}_{3}\right): \delta 1.18-1.34(\mathrm{~m}, 3 \mathrm{H}), 1.49-1.55(\mathrm{~m}, 2 \mathrm{H})$, $1.70-1.76(\mathrm{~m}, 2 \mathrm{H}), 2.12-2.18(\mathrm{~m}, 2 \mathrm{H}), 2.22(\mathrm{t}, J=2.5 \mathrm{~Hz}, 1 \mathrm{H})$, 2.55-2.59 (m, 2H), 2.84-2.89 (m, $2 \mathrm{H}), 3.27(\mathrm{~d}, J=2.5 \mathrm{~Hz}, 2 \mathrm{H})$, 
7.06-7.10 (m, 2H), 7.20-7.24 (m, 2H). ${ }^{13} \mathrm{C}$ NMR (100 MHz, $\left.\mathrm{CDCl}_{3}\right): \delta 32.11,32.32,34.60,38.09,47.13,52.42,72.82,79.10$, 128.28, 129.55, 131.21, 140.97. HRMS (ESI+): $\mathrm{m} / z$ calcd for $\mathrm{C}_{16} \mathrm{H}_{21} \mathrm{ClN}[\mathrm{M}+\mathrm{H}]^{+}$262.1363; found 262.1362. IR (ATR): 3219, 2931, 2919, 2863, 2801, 2758, 1492, 1451, 1407, 1335, 1282, 1261, $1138,1121,1109,1084,1015,992,974,826,797,729,688,631,539$ $\mathrm{cm}^{-1}$. HPLC purity, $100 \%\left(t_{\mathrm{R}}=9.90 \mathrm{~min}\right)$.

4-(4-Methoxyphenethyl)-1-(prop-2-yn-1-yl)piperidine (99). Synthesized from $62(0.230 \mathrm{~g}, 0.720 \mathrm{mmol}, 1.0$ equiv $)$ via general procedures D and E. Column chromatography, EtOAc/n-hex $=1 / 1$ (v/v). Yield: $57 \%$ (103 mg); white crystals, mp $31-32{ }^{\circ} \mathrm{C} .{ }^{1} \mathrm{H}$ NMR $\left(400 \mathrm{MHz}, \mathrm{CDCl}_{3}\right): \delta 1.22-1.36(\mathrm{~m}, 3 \mathrm{H}), 1.50-1.56(\mathrm{~m}, 2 \mathrm{H})$, $1.73-1.77(\mathrm{~m}, 2 \mathrm{H}), 2.13-2.19(\mathrm{~m}, 2 \mathrm{H}), 2.23(\mathrm{t}, J=2.5 \mathrm{~Hz}, 1 \mathrm{H})$, 2.54-2.58 (m, $2 \mathrm{H}), 2.85-2.90(\mathrm{~m}, 2 \mathrm{H}), 3.28(\mathrm{~d}, J=2.5 \mathrm{~Hz}, 2 \mathrm{H})$, $3.77(\mathrm{~s}, 3 \mathrm{H}), 6.80-6.84(\mathrm{~m}, 2 \mathrm{H}), 7.07-7.10(\mathrm{~m}, 2 \mathrm{H}) .{ }^{13} \mathrm{C}$ NMR $(100$ $\left.\mathrm{MHz}, \mathrm{CDCl}_{3}\right): \delta 32.01,32.14,34.57,38.46,47.13,52.46,55.10$, $72.77,79.15,113.60,129.04,134.60,157.51$. HRMS (ESI+): $\mathrm{m} / z$ calcd for $\mathrm{C}_{17} \mathrm{H}_{24} \mathrm{NO}[\mathrm{M}+\mathrm{H}]^{+} 258.1858$; found 258.1857. IR (ATR): $3273,2926,2908,2850,2806,1609,1510,1314,1250,1238,1175$, 1101, 1031, 975, 898, 832, 812, 702, 640, 577, $523 \mathrm{~cm}^{-1}$. HPLC purity, $100 \%\left(t_{\mathrm{R}}=8.95 \mathrm{~min}\right)$.

1-(Prop-2-yn-1-yl)-4-(4-(trifluoromethyl)phenethyl)piperidine (100). Synthesized from $63(0.23 \mathrm{~g}, 0.64 \mathrm{mmol}, 1.0$ equiv) via general procedures $\mathrm{D}$ and $\mathrm{E}$. Column chromatography, EtOAc/n-hex $=1 / 2(\mathrm{v} / \mathrm{v})$. Yield: $7 \%(14 \mathrm{mg})$; brown crystals, $\mathrm{mp}$ 31-33 ${ }^{\circ} \mathrm{C} .{ }^{1} \mathrm{H}$ NMR $\left(400 \mathrm{MHz}, \mathrm{CDCl}_{3}\right): \delta 1.23-1.37(\mathrm{~m}, 3 \mathrm{H})$, 1.54-1.60 (m, 2H), 1.74-1.78 (m, 2H), 2.14-2.20 (m, 2H), $2.23(\mathrm{t}$, $J=2.4 \mathrm{~Hz}, 1 \mathrm{H}), 2.65-2.70(\mathrm{~m}, 2 \mathrm{H}), 2.86-2.90(\mathrm{~m}, 2 \mathrm{H}), 3.29(\mathrm{~d}, J=$ $2.4 \mathrm{~Hz}, 2 \mathrm{H}), 7.26-7.28(\mathrm{~m}, 2 \mathrm{H}), 7.51-7.53(\mathrm{~m}, 2 \mathrm{H}) .{ }^{13} \mathrm{C}$ NMR $(100$ $\left.\mathrm{MHz}, \mathrm{CDCl}_{3}\right): \delta 32.14,32.91,34.71,37.97,47.17,52.45,72.89$, $79.11,124.34\left(\mathrm{q}, J_{\mathrm{C}, \mathrm{F}}=270.0 \mathrm{~Hz}\right), 125.20\left(\mathrm{q}, J_{\mathrm{C}, \mathrm{F}}=7.9 \mathrm{~Hz}\right), 128.02$ $\left(\mathrm{q}, J_{\mathrm{C}, \mathrm{F}}=32.3 \mathrm{~Hz}\right) 128.57,146.77$. HRMS (ESI +$): \mathrm{m} / z$ calcd for $\mathrm{C}_{17} \mathrm{H}_{21} \mathrm{~F}_{3} \mathrm{~N}[\mathrm{M}+\mathrm{H}]^{+}$296.1626; found 296.1625. IR (ATR): 3153, 2932, 2852, 2798, 1615, 1429, 1318, 1157, 1116, 1093, 1065, 1017, $978,910,854,831,735,682,637,598,552,511 \mathrm{~cm}^{-1}$. HPLC purity, $100 \%\left(t_{\mathrm{R}}=10.29 \mathrm{~min}\right)$.

1-(Prop-2-yn-1-yl)-4-(3-(trifluoromethyl)phenethyl)piperidine (101). Synthesized from $64(0.27 \mathrm{~g}, 0.76 \mathrm{mmol}, 1.0$ equiv) via general procedures $\mathrm{D}$ and $\mathrm{E}$. Column chromatography, EtOAc/n-hex $=1 / 3(\mathrm{v} / \mathrm{v})$. Yield: $29 \%(65 \mathrm{mg})$; yellow-orange oil. ${ }^{1} \mathrm{H}$ NMR (400 MHz, CDCl $): \delta 1.22-1.37(\mathrm{~m}, 3 \mathrm{H}), 1.54-1.59(\mathrm{~m}, 2 \mathrm{H})$, $1.72-1.78(\mathrm{~m}, 2 \mathrm{H}), 2.14-2.19(\mathrm{~m}, 2 \mathrm{H}), 2.22(\mathrm{t}, J=2.4 \mathrm{~Hz}, 1 \mathrm{H})$, 2.64-2.69 (m, 2H), 2.86-2.90 (m, 2H), $3.28(\mathrm{~d}, J=2.46 \mathrm{~Hz}, 2 \mathrm{H})$, $7.32-7.43(\mathrm{~m}, 4 \mathrm{H}) .{ }^{13} \mathrm{C}$ NMR $\left(100 \mathrm{MHz}, \mathrm{CDCl}_{3}\right): \delta 32.10,32.88$, $34.82,38.03,47.13,52.43,72.86,79.07,122.51\left(\mathrm{q}, J_{\mathrm{C}, \mathrm{F}}=3.8 \mathrm{~Hz}\right)$, $124.21\left(\mathrm{q}, J_{\mathrm{C}, \mathrm{F}}=272.2 \mathrm{~Hz}\right), 124.88\left(\mathrm{q}, J_{\mathrm{C}, \mathrm{F}}=3.7 \mathrm{~Hz}\right), 128.63,130.51$ $\left(\mathrm{q}, J_{\mathrm{C}, \mathrm{F}}=31.8 \mathrm{~Hz}\right), 131.64,143.48$. HRMS (ESI $): \mathrm{m} / \mathrm{z}$ calcd for $\mathrm{C}_{17} \mathrm{H}_{21} \mathrm{NF}_{3}[\mathrm{M}+\mathrm{H}]^{+}$296.1626; found 296.1629. IR (ATR): 3308, 2923, 2849, 2804, 2757, 1449, 1329, 1199, 1161, 1121, 1072, 976, $900,879,800,735,702,660,631 \mathrm{~cm}^{-1}$. HPLC purity, $98.7 \%\left(t_{\mathrm{R}}=\right.$ $10.25 \mathrm{~min})$.

4-(2-(1-(Prop-2-yn-1-yl)piperidin-4-yl)ethyl)benzonitrile (102). Synthesized from 65 (0.075 g, $0.239 \mathrm{mmol}, 1.0$ equiv) via general procedures $\mathrm{D}$ and $\mathrm{E}$. Column chromatography, EtOAc/n-hex $=1 / 1(\mathrm{v} / \mathrm{v})$. Yield: $59 \%(106 \mathrm{mg})$; white crystals, mp $40-42{ }^{\circ} \mathrm{C} .{ }^{1} \mathrm{H}$ NMR (400 MHz, $\left.\mathrm{CDCl}_{3}\right): \delta 1.20-1.36(\mathrm{~m}, 3 \mathrm{H}), 1.53-1.58(\mathrm{~m}, 2 \mathrm{H})$, $1.72-1.77(\mathrm{~m}, 2 \mathrm{H}), 2.13-2.19(\mathrm{~m}, 2 \mathrm{H}), 2.22(\mathrm{t}, J=2.4 \mathrm{~Hz}, 1 \mathrm{H})$, 2.65-2.69 (m, $2 \mathrm{H}), 2.85-2.90(\mathrm{~m}, 2 \mathrm{H}), 3.28(\mathrm{~d}, J=2.5 \mathrm{~Hz}, 2 \mathrm{H})$, 7.25-7.28 (m, 2H), 7.54-7.57 (m, 2H). ${ }^{13} \mathrm{C}$ NMR (100 MHz, $\left.\mathrm{CDCl}_{3}\right): \delta 31.99,33.13,34.62,37.60,47.03,52.28,72.82,78.97$, $109.39,118.96,128.96,132.01,148.23$. HRMS (ESI+): $\mathrm{m} / z$ calcd for $\mathrm{C}_{17} \mathrm{H}_{21} \mathrm{~N}_{2}[\mathrm{M}+\mathrm{H}]^{+}$253.1705; found 253.1706. IR (ATR): 3270, 2925, 2795, 2224, 1606, 1424, 1326, 1310, 1180, 1137, 1105, 977, $901,852,836,821,766,682,573,545 \mathrm{~cm}^{-1}$. HPLC purity, $96.0 \%\left(t_{\mathrm{R}}\right.$ $=8.42 \mathrm{~min})$.

1-(Prop-2-yn-1-yl)-4-(4-propylphenethyl)piperidine (103). Synthesized from $66(0.185 \mathrm{~g}, 0.561 \mathrm{mmol}, 1.0$ equiv $)$ via general procedures D and E. Column chromatography, EtOAc/n-hex $=1 / 2$ (v/v). Yield: 45\% (68 mg); pale yellow oil. ${ }^{1} \mathrm{H}$ NMR (400 MHz, $\left.\mathrm{CDCl}_{3}\right): \delta 0.95(\mathrm{t}, J=7.4 \mathrm{~Hz}, 3 \mathrm{H}), 1.25-1.37(\mathrm{~m}, 3 \mathrm{H}), 1.53-1.59$ (m, $2 \mathrm{H}), 1.60-1.68(\mathrm{~m}, 2 \mathrm{H}), 1.76-1.80(\mathrm{~m}, 2 \mathrm{H}), 2.15-2.21(\mathrm{~m}$, $2 \mathrm{H}), 2.23(\mathrm{t}, J=2.4 \mathrm{~Hz}, 1 \mathrm{H}), 2.53-2.62(\mathrm{~m}, 4 \mathrm{H}), 2.87-2.91(\mathrm{~m}$, $2 \mathrm{H}), 3.30(\mathrm{~d}, J=2.4 \mathrm{~Hz}, 2 \mathrm{H}), 7.07-7.11(\mathrm{~m}, 4 \mathrm{H}) .{ }^{13} \mathrm{C}$ NMR $(100$ $\left.\mathrm{MHz}, \mathrm{CDCl}_{3}\right): \delta 13.86,24.60,32.20,32.60,34.75,37.61,38.37$, 47.19, 52.53, 72.80, 79.20, 128.07, 128.32, 139.80 139.88. HRMS (ESI+): $m / z$ calcd for $\mathrm{C}_{19} \mathrm{H}_{28} \mathrm{~N}[\mathrm{M}+\mathrm{H}]^{+} 270.2216$; found 270.2215 . IR (ATR): 3008, 2925, 2852, 2801, 2753, 1513, 1454, 1337, 1312, $1117,1106,1021,976,897,806,787,679,645,623,503 \mathrm{~cm}^{-1}$. HPLC purity, $97.1 \%\left(t_{\mathrm{R}}=11.12 \mathrm{~min}\right)$.

(Z)-4-(2-(1-(Prop-2-yn-1-yl)piperidin-4-yl)vinyl)benzamide (104). Synthesized from 87 ( $0.065 \mathrm{~g}, 0.260 \mathrm{mmol}, 1.0$ equiv) via general procedure $\mathrm{F}$. Column chromatography, $\mathrm{CH}_{2} \mathrm{Cl}_{2} / \mathrm{MeOH}=$ 20/1 (v/v). Yield: $46 \%(32 \mathrm{mg})$; white crystals, $\mathrm{mp} 127-130{ }^{\circ} \mathrm{C} .{ }^{1} \mathrm{H}$ $\operatorname{NMR}\left(400 \mathrm{MHz}, \mathrm{CDCl}_{3}\right): \delta 1.49-1.59(\mathrm{~m}, 2 \mathrm{H}), 1.68-1.74(\mathrm{~m}, 2 \mathrm{H})$, $2.20(\mathrm{td}, J=11.7,2.6 \mathrm{~Hz}, 2 \mathrm{H}), 2.23(\mathrm{t}, J=2.4 \mathrm{~Hz}, 1 \mathrm{H}), 2.46-2.57$ $(\mathrm{m}, 1 \mathrm{H}), 2.87(\mathrm{dt}, J=11.0,2.4 \mathrm{~Hz}, 2 \mathrm{H}), 3.28(\mathrm{~d}, J=2.5 \mathrm{~Hz}, 2 \mathrm{H})$, 5.57 (dd, $J=11.7,10.1 \mathrm{~Hz}, 1 \mathrm{H}), 6.27(\mathrm{bs}, 2 \mathrm{H}), 6.39$ (d, $J=11.7 \mathrm{~Hz}$, $1 \mathrm{H}), 7.27-7.30(\mathrm{~m}, 2 \mathrm{H}), 7.77-7.80(\mathrm{~m}, 2 \mathrm{H}) .{ }^{13} \mathrm{C} \mathrm{NMR}(100 \mathrm{MHz}$, $\left.\mathrm{CDCl}_{3}\right): \delta 32.12,34.58,47.19,51.77,73.07,78.89,127.17,127.34$, 128.61, 131.35, 139.00, 141.40, 169.32. HRMS (ESI $+: \mathrm{m} / z$ calcd for $\mathrm{C}_{17} \mathrm{H}_{21} \mathrm{~N}_{2} \mathrm{O}[\mathrm{M}+\mathrm{H}]^{+}$269.1654; found 269.1652. IR (ATR): 3331, $3307,3285,3204,2928,2806,1658,1604,1550,1418,1386,1309$, $1259,1131,1122,1104,969,856,794,765,736,659,636,509 \mathrm{~cm}^{-1}$. HPLC purity, $98.2 \%\left(t_{\mathrm{R}}=6.34 \mathrm{~min}\right)$.

(E)-4-(2-(1-(Prop-2-yn-1-yl)piperidin-4-yl)vinyl)benzamide (105). Synthesized from 88 ( $0.080 \mathrm{~g}, 0.320 \mathrm{mmol}, 1.0$ equiv) via general procedure F. Column chromatography, $\mathrm{CH}_{2} \mathrm{Cl}_{2} / \mathrm{MeOH}=$ 20/1 (v/v). Yield: $63 \%(54 \mathrm{mg})$; white crystals, $\mathrm{mp} 181-184{ }^{\circ} \mathrm{C} .{ }^{1} \mathrm{H}$ NMR $\left(400 \mathrm{MHz}\right.$, DMSO- $\left.d_{6}\right): \delta 1.42(\mathrm{dq}, J=12.7,3.9 \mathrm{~Hz}, 2 \mathrm{H})$, $1.72-1.75(\mathrm{~m}, 2 \mathrm{H}), 2.06-2.12(\mathrm{~m}, 1 \mathrm{H}), 2.17(\mathrm{td}, J=11.5,2.2 \mathrm{~Hz}$, $2 \mathrm{H}), 2.79-2.83(\mathrm{~m}, 2 \mathrm{H}), 3.14(\mathrm{t}, J=2.4 \mathrm{~Hz}, 1 \mathrm{H}), 3.26(\mathrm{~d}, J=2.4 \mathrm{~Hz}$, $2 \mathrm{H}), 6.36-6.46(\mathrm{~m}, 2 \mathrm{H}), 7.30$ (bs, $1 \mathrm{H}), 7.45-7.47(\mathrm{~m}, 2 \mathrm{H}), 7.80-$ $7.82(\mathrm{~m}, 2 \mathrm{H}), 7.93$ (bs, $1 \mathrm{H}) .{ }^{13} \mathrm{C}$ NMR (100 MHz, DMSO- $\left.d_{6}\right): \delta$ $31.34,38.32,46.38,51.42,75.53,79.53,125.53,126.96,127.75$, 132.40, 137.04, 139.99, 167.43. HRMS (ESI +$): m / z$ calcd for $\mathrm{C}_{17} \mathrm{H}_{21} \mathrm{~N}_{2} \mathrm{O}[\mathrm{M}+\mathrm{H}]^{+}$269.1654; found 269.1656. IR (ATR): 3401, $3281,3147,2937,2913,2805,1645,1614,1564,1442,1415,1393$, $1313,1289,1221,1136,1101,976,870,829,800,767,682,647,635$, $599,544 \mathrm{~cm}^{-1}$. HPLC purity, $99.4 \%\left(t_{\mathrm{R}}=6.20 \mathrm{~min}\right)$.

4-(2-(1-(Prop-2-yn-1-yl)piperidin-4-yl)ethyl)benzamide (106). Synthesized from $102(0.075 \mathrm{~g}, 0.297 \mathrm{mmol}, 1.0$ equiv) via general procedure F. Column chromatography, $\mathrm{CH}_{2} \mathrm{Cl}_{2} / \mathrm{MeOH}=9$ / 1 (v/v). Yield: $42 \%(34 \mathrm{mg})$; white crystals, $\mathrm{mp} 155-158{ }^{\circ} \mathrm{C} .{ }^{1} \mathrm{H}$ NMR $(400 \mathrm{MHz}, \mathrm{MeOD}): \delta 1.28-1.36(\mathrm{~m}, 3 \mathrm{H}), 1.58-1.63(\mathrm{~m}$, $2 \mathrm{H}), 1.80-1.83(\mathrm{~m}, 2 \mathrm{H}), 2.21(\mathrm{t}, J=11.3 \mathrm{~Hz}, 2 \mathrm{H}), 2.69(\mathrm{t}, J=2.5$ $\mathrm{Hz}, 1 \mathrm{H}), 2.70-2.74(\mathrm{~m}, 2 \mathrm{H}), 2.94-2.99(\mathrm{~m}, 2 \mathrm{H}), 3.29$ (d, $J=2.5 \mathrm{~Hz}$, $2 \mathrm{H}), 7.30-7.32(\mathrm{~m}, 2 \mathrm{H}), 7.79-7.82(\mathrm{~m}, 2 \mathrm{H})$, resonances for $\mathrm{NH}_{2}$ missing (exchange with MeOD). ${ }^{13} \mathrm{C}$ NMR (100 MHz, MeOD): $\delta$ $32.74,33.88$, 35.92, 39.11, 47.65, 53.55, 75.10, 79.19, 128.82, 129.50, $132.39,148.40,172.38$. HRMS (ESI+): $m / z$ calcd for $\mathrm{C}_{17} \mathrm{H}_{23} \mathrm{~N}_{2} \mathrm{O}[\mathrm{M}$ $+\mathrm{H}]^{+}$269.1810; found 269.1816. IR (ATR): 3178, 2932, 2919, 2847, $2798,2752,2543,2373,1610,1563,1421,1404,1333,1270,1186$, $1144,1103,1019,973,915,859,767,755,709,594 \mathrm{~cm}^{-1}$. HPLC purity, $99.6 \%\left(t_{\mathrm{R}}=6.29 \mathrm{~min}\right)$.

4-(2-(1-(Prop-2-yn-1-yl)piperidin-4-yl)ethyl)phenol (107). The methoxy substituted compound $99(50 \mathrm{mg}, 0.194 \mathrm{mmol}, 1.0$ equiv) was dissolved in anhydrous toluene $(6 \mathrm{~mL})$ under argon and cooled to $-20{ }^{\circ} \mathrm{C}$. $\mathrm{BBr}_{3}\left(1 \mathrm{M}\right.$ in $\mathrm{CH}_{2} \mathrm{Cl}_{2}, 582 \mu \mathrm{L}, 0.582 \mathrm{mmol}, 3.0$ equiv) was added dropwise and the reaction mixture was stirred for another hour at $-20{ }^{\circ} \mathrm{C}$. The mixture was allowed to warm up to room temperature $(1 \mathrm{~h})$. Saturated aqueous $\mathrm{NaHCO}_{3}(10 \mathrm{~mL})$ was added, and the resulting emulsion was stirred vigorously for $15 \mathrm{~min}$ before EtOAc $(30 \mathrm{~mL})$ was added. The phases were separated, and the organic layer was washed with saturated brine $(50 \mathrm{~mL})$, dried over $\mathrm{Na}_{2} \mathrm{SO}_{4}$, and evaporated. Column chromatography, $\mathrm{CH}_{2} \mathrm{Cl}_{2} / \mathrm{MeOH}$ $=20 / 1(\mathrm{v} / \mathrm{v})$. Yield: $57 \%(27 \mathrm{mg})$; white crystals, $\mathrm{mp} 104-106{ }^{\circ} \mathrm{C}$. ${ }^{1} \mathrm{H}$ NMR $\left(400 \mathrm{MHz}, \mathrm{CDCl}_{3}\right): \delta 1.23-1.39(\mathrm{~m}, 3 \mathrm{H}), 1.48-1.54(\mathrm{~m}$, $2 \mathrm{H}), 1.73-1.79(\mathrm{~m}, 2 \mathrm{H}), 2.21-2.27(\mathrm{~m}, 2 \mathrm{H}), 2.25(\mathrm{t}, J=2.4 \mathrm{~Hz}$, $1 \mathrm{H}), 2.51-2.55(\mathrm{~m}, 2 \mathrm{H}), 2.90-2.94(\mathrm{~m}, 2 \mathrm{H}), 3.32(\mathrm{~d}, J=2.5 \mathrm{~Hz}$, $2 \mathrm{H}), 6.71-6.73(\mathrm{~m}, 2 \mathrm{H}), 6.99-7.02(\mathrm{~m}, 2 \mathrm{H})$, resonance for $\mathrm{OH}$ 
missing (exchange with water in solvent). ${ }^{13} \mathrm{C}$ NMR $(100 \mathrm{MHz}$, $\left.\mathrm{CDCl}_{3}\right): \delta 31.89,32.09,34.56,38.41,47.07,52.42,73.33,78.68$, $115.28,129.27,134.34,153.91$. HRMS (ESI+): $\mathrm{m} / z$ calcd for $\mathrm{C}_{16} \mathrm{H}_{22} \mathrm{NO}[\mathrm{M}+\mathrm{H}]^{+}$244.1701; found 244.1697. IR (ATR): 3278, $2909,2853,2815,2598,1614,1593,1515,1464,1392,1337,1269$, $1249,1170,1116,974,819,785,692,636,563,516,501 \mathrm{~cm}^{-1}$. HPLC purity, $96.1 \%\left(t_{\mathrm{R}}=7.17 \mathrm{~min}\right)$.

Preparation of Hydrochloride Salts. Compounds 1, 6, 67, 69, 84, 97, and 100 were transformed into corresponding hydrochloride salts following the described procedure. Compound in the form of a free base (0.2-2.5 g, 1.0 equiv) was dissolved in $\mathrm{MeOH}(5-20 \mathrm{~mL})$. Then a $2 \mathrm{M}$ solution of $\mathrm{HCl}$ in $\mathrm{Et}_{2} \mathrm{O}$ (2.0 equiv) was added at room temperature under vigorous stirring with magnetic stirrer. The precipitate formed was filtered off, washed with $\mathrm{Et}_{2} \mathrm{O}$ (50-100 $\mathrm{mL}$ ), and dried at reduced pressure to obtain hydrochloride salts. These salts were used for the crystallization, permeability, ex vivo and in vivo experiments.

Biology. Protein Production, Enzymatic Assays, and X-ray Crystallography. All of the reagents were purchased from SigmaAldrich unless specified otherwise. The effects of the compounds on hMAO-A and hMAO-B were first investigated by determining the $\mathrm{IC}_{50}$ values using a previously described fluorimetric assay. ${ }^{42}$ The inhibitory activities of the compounds were determined according to their effects on the generation of hydrogen peroxide $\left(\mathrm{H}_{2} \mathrm{O}_{2}\right)$ as a sideproduct of hMAO activity. For details on protein production, enzymatic assays, and X-ray crystallography, see Supporting Information.

Cell Culture and Treatments. The human neuroblastoma SHSY5Y cell line was purchased from American Type Culture Collection (CRL-2266; VA, USA). These cells were cultured in Advanced Dulbecco's modified Eagle's medium (Gibco, Thermo Fisher Scientific, MA, USA) supplemented with $10 \%$ fetal bovine serum (Gibco), $2 \mathrm{mM}$ L-glutamine, $50 \mathrm{U} / \mathrm{mL}$ penicillin, and $50 \mu \mathrm{g} / \mathrm{mL}$ streptomycin (Sigma, MO, USA) in a humidified atmosphere of $95 \%$ air and $5 \% \mathrm{CO}_{2}$ at $37{ }^{\circ} \mathrm{C}$ and grown to $80 \%$ confluence. Prior to cell treatments, the complete medium was replaced with serum-depleted medium. Compounds were prepared as stock solutions of $20 \mathrm{mM}$ in DMSO and were used at concentrations of 5-50 $\mu \mathrm{M}$. For the cytotoxic stimuli, the $10 \mathrm{mM}$ 6-OHDA (Sigma, MO, USA) stock was prepared in phosphate buffered saline, $\mathrm{pH} 7.4$, with $0.01 \%$ ascorbic acid. For the detailed experimental procedures see Supporting Information.

Animals. Adult male Swiss mice (weight, $25-30 \mathrm{~g}$ ) and adult male Wistar rats (weight, 200-300 g) were obtained from the Central Animal House of the School of Pharmacy and Biochemistry, University of Buenos Aires, Buenos Aires, Argentina. For behavioral assays, the mice were housed in groups of five in a controlled environment $\left(20-23{ }^{\circ} \mathrm{C}\right)$, with free access to food and water, and maintained on a $12 \mathrm{~h} / 12 \mathrm{~h}$ day/night cycle, with light on at 07:00 h. The housing, handling, and experimental procedures for both the mice and rats complied with the recommendations set out by the National Institutes of Health Guide for Care and Use of Laboratory Animals (NIH Publication No. 8023, revised 1996) and the Institutional Committees for the Care and Use of Laboratory Animals of the Faculty of Pharmacy and Biochemistry, University of Buenos Aires, Argentina (Code 31682/2014). All efforts were taken to minimize animal suffering. The number of animals used was the minimum number consistent with obtaining significant data. The mice were randomly assigned to the treatment groups and were used only once. The pharmacological tests were evaluated by experimenters who were not aware of the treatments administered and were performed between 10:00 $\mathrm{h}$ and 14:00 $\mathrm{h}$.

Administrations and Procedures. The test compounds (used as their hydrochloride salts) were dissolved in $0.9 \%$ saline. Haloperidol, diazepam, and imipramine were diluted by sequential additions of DMSO, an aqueous solution of $0.25 \%$ Tween 80 , and $0.9 \%$ saline to their final concentrations of $5 \%, 20 \%$, and $75 \%$, respectively. In each session, a control group of mice received only vehicle, in parallel with the mice that received the drug treatments. The volumes of the ip injections and oral gavage (po) administrations were $0.10-0.20 \mathrm{~mL} /$
$30 \mathrm{~g}$ body weight and $0.30 \mathrm{~mL} / 30 \mathrm{~g}$ body weight, respectively. The protein concentrations in the mouse brain homogenates were determined using the method of Bradford, with bovine serum albumin as the standard.

For the acute behavioral assays, all of the compounds were tested $30 \mathrm{~min}$ after ip administrations. For the chronical treatments, the mice were injected ip with $0.3 \mathrm{mg} / \mathrm{kg} \mathrm{69,100}$ or $0.9 \%$ saline (control group) once a day between 09:00 and 10:00 h over 10 consecutive days. On days $1,3,5,7$, and 9 , these mice were weighted. On day 8 , at 30 min after the relevant ip treatment, the mice were submitted to the plus maze (for 69) or the hole-board tests (for 100), and their locomotor activity was recorded immediately afterward. On day 10 , at $30 \mathrm{~min}$ after the relevant ip treatment, the mice were submitted to the tail suspension test (for 69) or the haloperidol-induced catalepsy assay (for 100) (Figures S10 and S11). For all of these behavioral assays, the arena/apparatus was cleaned with $60 \%$ ethanol between each trial with each mouse. Behavioral assays are described in detail in Supporting Information.

Mouse Brain Homogenate Preparation. The mice were killed humanely by decapitation at $30 \mathrm{~min}$ after drug or $0.9 \%$ saline treatment (for acute ip injections), at $60 \mathrm{~min}$ after drug or $0.9 \%$ saline treatment (for acute oral gavage), or on day 10 at $90 \mathrm{~min}$ after the last drug or $0.9 \%$ saline ip treatment after the tail suspension test (for the mice chronically treated with 69) or after haloperidol-induced catalepsy test (for the mice chronically treated with 100). Also, three mice that were chronically treated with $\mathbf{1 0 0}$ or $0.9 \%$ saline ip but without the haloperidol injection were also tested to determine any haloperidol effects in the ex vivo MAO-B activity assay (Figures S10 and S11). After removal of the olfactory bulb, the whole mouse brains were washed several times in ice-cold $50 \mathrm{mM}$ potassium phosphate buffer ( $\mathrm{pH} 7.4,0.05 \%[\mathrm{v} / \mathrm{v}]$ Triton X-114). Then, each brain was independently homogenized using a blender homogenizer (PRO Scientific Inc., CT, USA) at $30000 \mathrm{rpm}$ for $1 \mathrm{~min}$, in $1.5 \mathrm{~mL}$ of 100 $\mathrm{mM}$ potassium phosphate buffer ( $\mathrm{pH} 7.4,0.1 \%$ [v/v] Triton X-114) at $4{ }^{\circ} \mathrm{C}$ (in ice). The homogenate was then centrifuged at $3000 \mathrm{~g}$ for $20 \mathrm{~min}$ at $4{ }^{\circ} \mathrm{C}$. The supernatant was stored at $-20{ }^{\circ} \mathrm{C}$ until the following day for the MAO inhibition assays.

Ex Vivo MAO Inhibition Assay. The ex vivo effects of 69 on MAO-A and 100 on MAO-B enzymatic activities (ip or oral administration, $30 \mathrm{~min}$ before decapitation) in the mouse brain homogenates were investigated using a previously described fluorimetric assay, with minor modifications. ${ }^{42}$ For details see Supporting Information.

\section{ASSOCIATED CONTENT}

\section{Supporting Information}

The Supporting Information is available free of charge at https://pubs.acs.org/doi/10.1021/acs.jmedchem.9b01886.

Supplementary figures, supplementary tables, supplementary results and discussion, supplementary methods, HPLC traces for representative final compounds, and ${ }^{1} \mathrm{H}$ and ${ }^{13} \mathrm{C}$ NMR spectra for final compounds (PDF) Movie for undocking experiment, MAO-A (MP4) Movie for undocking experiment, MAO-B (MP4) Molecular formula strings and activity data (CSV) Model of undocking in Figure 3 (PDB) Model of undocking in Figure 3 (PDB) Model of undocking in Figure 3 (PDB) Model of undocking in Figure 3 (PDB)

\section{Accession Codes}

The coordinates and structure factors have been deposited in the PDB under accession codes 6RKB (compound 1), 6RKP (compound 84), and 6RLE (compound 97). Authors will release the atomic coordinates and experimental data upon article publication. 


\section{AUTHOR INFORMATION}

\section{Corresponding Authors}

Claudia Binda - Department of Biology and Biotechnology, University of Pavia, Pavia 27100, Italy; ๑ orcid.org/00000003-2038-9845; Email: claudia.binda@unipv.it

Mariel Marder - Universidad de Buenos Aires, Consejo Nacional de Investigaciones Cientificas y Técnicas, and Instituto de Quimica y Fisicoquimica Biologicas, Facultad de Farmacia y Bioquimica, Universidad de Buenos Aires, Buenos Aires C1113AAD, Argentina; Email: mmarder@qb.ffyb.uba.ar

Stanislav Gobec - Faculty of Pharmacy, University of Ljubljana, Ljubljana 1000, Slovenia; @ orcid.org/0000-0002-9678-

3083; Email: stanislav.gobec@ffa.uni-lj.si

\section{Authors}

Damijan Knez - Faculty of Pharmacy, University of Ljubljana, Ljubljana 1000, Slovenia

Natalia Colettis - Universidad de Buenos Aires, Consejo Nacional de Investigaciones Cientificas y Técnicas, and Instituto de Quimica y Fisicoquimica Biologicas, Facultad de Farmacia y Bioquimica, Universidad de Buenos Aires, Buenos Aires C1113AAD, Argentina

Luca G. Iacovino - Department of Biology and Biotechnology, University of Pavia, Pavia 27100, Italy

Matej Sova - Faculty of Pharmacy, University of Ljubljana, Ljubljana 1000, Slovenia

Anja Pišlar - Faculty of Pharmacy, University of Ljubljana, Ljubljana 1000, Slovenia

Janez Konc - National Institute of Chemistry, Ljubljana 1000, Slovenia

Samo Lešnik - National Institute of Chemistry, Ljubljana 1000, Slovenia

Josefina Higgs - Universidad de Buenos Aires, Consejo Nacional de Investigaciones Cientificas y Técnicas, and Instituto de Quimica y Fisicoquimica Biologicas, Facultad de Farmacia y Bioquimica, Universidad de Buenos Aires, Buenos Aires C1113AAD, Argentina

Fabiola Kamecki - Universidad de Buenos Aires, Consejo Nacional de Investigaciones Cientificas y Técnicas, and Instituto de Química y Fisicoquimica Biologicas, Facultad de Farmacia y Bioquimica, Universidad de Buenos Aires, Buenos Aires C1113AAD, Argentina

Irene Mangialavori - Universidad de Buenos Aires, Consejo Nacional de Investigaciones Cientificas y Técnicas, and Instituto de Quimica y Fisicoquimica Biologicas, Facultad de Farmacia y Bioquimica, Universidad de Buenos Aires, Buenos Aires C1113AAD, Argentina

Ana Dolšak - Faculty of Pharmacy, University of Ljubljana, Ljubljana 1000, Slovenia

Simon Zakelj - Faculty of Pharmacy, University of Ljubljana, Ljubljana 1000, Slovenia

Jurij Trontelj - Faculty of Pharmacy, University of Ljubljana, Ljubljana 1000, Slovenia

Janko Kos - Faculty of Pharmacy, University of Ljubljana, Ljubljana 1000, Slovenia

Complete contact information is available at:

https://pubs.acs.org/10.1021/acs.jmedchem.9b01886

\section{Author Contributions}

${ }^{\#}$ D.K., N.C., and L.G.I. contributed equally to this work. D.K. designed the inhibitors, performed the chemistry and in vitro MAO inhibition, participated in the inhibition kinetic studies, crystallographic studies, and ex vivo and in vivo evaluations, and oversaw the full study. N.C. performed the ex vivo and in vivo assays and contributed to the statistical analysis of the data. L.G.I. performed the inhibition kinetic studies and UV-vis measurements and refined and analyzed the crystallographic data. M.S. performed the chemistry. A.P. performed the cytotoxicity and neuroprotection assays with the SH-SY5Y cells. J.K. and S.L. performed the molecular modeling. J.H. performed the in vitro binding experiments and participated in the in vivo assays. F.K. performed the ex vivo assays and participated in the in vitro binding experiments. I.M. participated in the ex vivo assays and contributed to the statistical analysis of the data. A.D. performed the chemistry. S.Ž. performed the in vitro permeability assays and contributed to the LC-MS analysis. J.T. performed the LC-MS analysis. J.K. oversaw the cytotoxicity and neuroprotection assays with the SH-SY5Y cells. C.B. supervised the inhibition kinetic studies, UV-vis measurements, and crystallography analysis. M.M. designed and performed the in vivo experiments. S.G. designed and oversaw the project and contributed to the editing of the manuscript. All of the authors contributed to the design, analysis, and discussion of the research and the writing of the manuscript.

\section{Notes}

The authors declare no competing financial interest.

\section{ACKNOWLEDGMENTS}

This work was supported by ARRS (Grants P1-0208, L1-8157, BI-AR/15-17-003, P4-0127, L7-8269), Fondazione Cariplo (Grant 2014-0672), MIUR "Dipartimenti di Eccellenza" Programme (2018-2022), and European Community Seventh Framework Programme (FP7/2007-2013) under BioStruct-X (Grants 7551 and 10205) and CALIPSOplus (Horizon 2020 EC access program). Financial support is acknowledged from CONICET (PIP No. 112201501 00410), UBA (UBACyT No. 20020100100415 and 20020150100012BA), ANPCyT (PICT No. 2011-0328), and MINCYT. We thank ESRF (Grenoble) and SLS (Villigen) for use of synchrotrons. We also thank Chris Berrie for critical reading of the manuscript.

\section{ABBREVIATIONS USED}

DMSO, dimethylsulfoxide; FAD, flavin adenine dinucleotide; hMAO-A/B, human monoamine oxidases A and B; KHMDS, potassium bis(trimethylsilyl)amide; NaHMDS, sodium bis(trimethylsilyl)amide; n-hex, $n$-hexane; LDH, lactate dehydrogenase; MAO, monoamine oxidase; PI, propidium iodide; SAR, structure-activity relationship; TBTU, 2-( $1 H$-benzotriazole-1-yl)-1,1,3,3-tetramethylaminium tetrafluoroborate; THF, tetrahydrofuran

\section{REFERENCES}

(1) Persch, E.; Dumele, O.; Diederich, F. Molecular Recognition in Chemical and Biological Systems. Angew. Chem., Int. Ed. 2015, 54 (11), 3290-3327.

(2) Kasprzyk-Hordern, B. Pharmacologically Active Compounds in the Environment and Their Chirality. Chem. Soc. Rev. 2010, 39 (11), 4466-4503.

(3) Brooks, W. H.; Guida, W. C.; Daniel, K. G. The Significance of Chirality in Drug Design and Development. Curr. Top. Med. Chem. 2011, 11 (7), 760-770.

(4) Nafisi, S.; Norouzi, Z. A Comparative Study on the Interaction of Cis- and Trans-Platin with DNA and RNA. DNA Cell Biol. 2009, 28 (9), 469-477. 
(5) Robertson, D. W.; Katzenellenbogen, J. A.; Long, D. J.; Rorke, E. A.; Katzenellenbogen, B. S. Tamoxifen Antiestrogens. A Comparison of the Activity, Pharmacokinetics, and Metabolic Activation of the Cis and Trans Isomers of Tamoxifen. J. Steroid Biochem. 1982, 16 (1), 113.

(6) Gaspari, R.; Prota, A. E.; Bargsten, K.; Cavalli, A.; Steinmetz, M. O. Structural Basis of Cis- and Trans-Combretastatin Binding to Tubulin. Chem-US 2017, 2 (1), 102-113.

(7) Bach, A. W.; Lan, N. C.; Johnson, D. L.; Abell, C. W.; Bembenek, M. E.; Kwan, S. W.; Seeburg, P. H.; Shih, J. C. Cdna Cloning of Human Liver Monoamine Oxidase A and B: Molecular Basis of Differences in Enzymatic Properties. Proc. Natl. Acad. Sci. U. S. A. 1988, 85 (13), 4934-4938.

(8) De Colibus, L.; Li, M.; Binda, C.; Lustig, A.; Edmondson, D. E.; Mattevi, A. Three-Dimensional Structure of Human Monoamine Oxidase A (Mao A): Relation to the Structures of Rat MAO A and Human MAO B. Proc. Natl. Acad. Sci. U. S. A. 2005, 102 (36), 12684-12689.

(9) Milczek, E. M.; Binda, C.; Rovida, S.; Mattevi, A.; Edmondson, D. E. The 'Gating' Residues Ile199 and Tyr326 in Human Monoamine Oxidase B Function in Substrate and Inhibitor Recognition. FEBS J. 2011, 278 (24), 4860-4869.

(10) Ramsay, R. R. Molecular Aspects of Monoamine Oxidase B. Prog. Neuro-Psychopharmacol. Biol. Psychiatry 2016, 69, 81-89.

(11) Ramsay, R. R.; Albreht, A. Kinetics, Mechanism, and Inhibition of Monoamine Oxidase. J. Neural Transm. (Vienna) 2018, 125 (11), $1659-1683$.

(12) Kim, D.; Baik, S. H.; Kang, S.; Cho, S. W.; Bae, J.; Cha, M. Y.; Sailor, M. J.; Mook-Jung, I.; Ahn, K. H. Close Correlation of Monoamine Oxidase Activity with Progress of Alzheimer's Disease in Mice, Observed by in Vivo Two-Photon Imaging. ACS Cent. Sci. 2016, 2 (12), 967-975.

(13) Schedin-Weiss, S.; Inoue, M.; Hromadkova, L.; Teranishi, Y.; Yamamoto, N. G.; Wiehager, B.; Bogdanovic, N.; Winblad, B.; Sandebring-Matton, A.; Frykman, S.; Tjernberg, L. O. Monoamine Oxidase B is Elevated in Alzheimer Disease Neurons, is Associated with $\gamma$-Secretase and Regulates Neuronal Amyloid $\beta$-Peptide Levels. Alzheimer's Res. Ther. 2017, 9 (1), 57.

(14) Chiuccariello, L.; Houle, S.; Miler, L.; Cooke, R. G.; Rusjan, P. M.; Rajkowska, G.; Levitan, R. D.; Kish, S. J.; Kolla, N. J.; Ou, X.; Wilson, A. A.; Meyer, J. H. Elevated Monoamine Oxidase A Binding During Major Depressive Episodes is Associated with Greater Severity and Reversed Neurovegetative Symptoms. Neuropsychopharmacology 2014, 39 (4), 973-980.

(15) Deshwal, S.; Di Sante, M.; Di Lisa, F.; Kaludercic, N. Emerging Role of Monoamine Oxidase as a Therapeutic Target for Cardiovascular Disease. Curr. Opin. Pharmacol. 2017, 33, 64-69.

(16) Shih, J. C. Monoamine Oxidase Isoenzymes: Genes, Functions and Targets for Behavior and Cancer Therapy. J. Neural Transm. (Vienna) 2018, 125 (11), 1553-1566.

(17) Thase, M. E. The Role of Monoamine Oxidase Inhibitors in Depression Treatment Guidelines. J. Clin. Psychiatry 2012, 73 (Suppl. 1), $10-16$.

(18) Dezsi, L.; Vecsei, L. Monoamine Oxidase B Inhibitors in Parkinson's Disease. CNS Neurol. Disord.: Drug Targets 2017, 16 (4), 425-439.

(19) Youdim, M. B. H. Monoamine Oxidase Inhibitors, and Iron Chelators in Depressive Illness and Neurodegenerative Diseases. J. Neural. Transm. (Vienna) 2018, 125 (11), 1719-1733.

(20) Youdim, M. B.; Edmondson, D.; Tipton, K. F. The Therapeutic Potential of Monoamine Oxidase Inhibitors. Nat. Rev. Neurosci. 2006, 7 (4), 295-309.

(21) Petrek, M.; Otyepka, M.; Banas, P.; Kosinova, P.; Koca, J.; Damborsky, J. Caver: A New Tool to Explore Routes from Protein Clefts, Pockets and Cavities. BMC Bioinf. 2006, 7, 316.

(22) Filipovič, J.; Vávra, O.; Plhák, J.; Bednář, D.; Marques, S. M.; Brezovský, J.; Matyska, L.; Damborský, J. CaverDock: A Novel Method for the Fast Analysis of Ligand Transport. arXiv 2018, 1809.03453 .
(23) Waldeck, D. H. Photoisomerization Dynamics of Stilbenes. Chem. Rev. 1991, 91 (3), 415-436.

(24) Albreht, A.; Vovk, I.; Mavri, J.; Marco-Contelles, J.; Ramsay, R. R. Evidence for a Cyanine Link between Propargylamine Drugs and Monoamine Oxidase Clarifies the Inactivation Mechanism. Front. Chem. 2018, 6, 169.

(25) Esteban, G.; Allan, J.; Samadi, A.; Mattevi, A.; Unzeta, M.; Marco-Contelles, J.; Binda, C.; Ramsay, R. R. Kinetic and Structural Analysis of the Irreversible Inhibition of Human Monoamine Oxidases by ASS234, a Multi-Target Compound Designed for Use in Alzheimer's Disease. Biochim. Biophys. Acta, Proteins Proteomics 2014, 1844 (6), 1104-1110.

(26) Binda, C.; Hubalek, F.; Li, M.; Herzig, Y.; Sterling, J.; Edmondson, D. E.; Mattevi, A. Crystal Structures of Monoamine Oxidase B in Complex with Four Inhibitors of the N-Propargylaminoindan Class. J. Med. Chem. 2004, 47 (7), 1767-1774.

(27) Reis, J.; Manzella, N.; Cagide, F.; Mialet-Perez, J.; Uriarte, E.; Parini, A.; Borges, F.; Binda, C. Tight-Binding Inhibition of Human Monoamine Oxidase B by Chromone Analogs: A Kinetic, Crystallographic, and Biological Analysis. J. Med. Chem. 2018, 61 (9), 42034212.

(28) Lopes, F. M.; Schroder, R.; da Frota Junior, M. L.; ZanottoFilho, A.; Muller, C. B.; Pires, A. S.; Meurer, R. T.; Colpo, G. D.; Gelain, D. P.; Kapczinski, F.; Moreira, J. C. F.; da Cruz Fernandes, M.; Klamt, F. Comparison between Proliferative and Neuron-Like SSSY5Y Cells as an in Vitro Model for Parkinson Disease Studies. Brain Res. 2010, 1337, 85-94.

(29) Finberg, J. P.; Rabey, J. M. Inhibitors of MAO-A and MAO-B in Psychiatry and Neurology. Front. Pharmacol. 2016, 7, 340.

(30) Shulman, K. I.; Herrmann, N.; Walker, S. E. Current Place of Monoamine Oxidase Inhibitors in the Treatment of Depression. CNS Drugs 2013, 27 (10), 789-797.

(31) Kircanski, K.; LeMoult, J.; Ordaz, S.; Gotlib, I. H. Investigating the Nature of Co-Occurring Depression and Anxiety: Comparing Diagnostic and Dimensional Research Approaches. J. Affective Disord. 2017, 216, 123-135.

(32) Akimova, E.; Lanzenberger, R.; Kasper, S. The Serotonin-1A Receptor in Anxiety Disorders. Biol. Psychiatry 2009, 66 (7), 627635.

(33) Fernandez, S. P.; Wasowski, C.; Loscalzo, L. M.; Granger, R. E.; Johnston, G. A.; Paladini, A. C.; Marder, M. Central Nervous System Depressant Action of Flavonoid Glycosides. Eur. J. Pharmacol. 2006, 539 (3), 168-176.

(34) Bali, A.; Jaggi, A. S. Preclinical Experimental Stress Studies: Protocols, Assessment and Comparison. Eur. J. Pharmacol. 2015, 746, 282-292.

(35) Tripathi, A. C.; Upadhyay, S.; Paliwal, S.; Saraf, S. K. Privileged Scaffolds as MAO Inhibitors: Retrospect and Prospects. Eur. J. Med. Chem. 2018, 145, 445-497.

(36) Holt, A. On the Practical Aspects of Characterising Monoamine Oxidase Inhibition in Vitro. J. Neural. Transm. (Vienna) 2018, 125 (11), 1685-1705.

(37) Pettersson, F.; Svensson, P.; Waters, S.; Waters, N.; Sonesson, C. Synthesis and Evaluation of a Set of Para-Substituted 4Phenylpiperidines and 4-Phenylpiperazines as Monoamine Oxidase (MAO) Inhibitors. J. Med. Chem. 2012, 55 (7), 3242-3249.

(38) Heuson, E.; Storgaard, M.; Huynh, T. H.; Charmantray, F.; Gefflaut, T.; Bunch, L. Profiling Substrate Specificity of Two Series of Phenethylamine Analogs at Monoamine Oxidase A and B. Org. Biomol. Chem. 2014, 12 (43), 8689-8695.

(39) Kumar, S.; Ali, J.; Baboota, S. Design Expert(®) Supported Optimization and Predictive Analysis of Selegiline Nanoemulsion Via the Olfactory Region with Enhanced Behavioural Performance in Parkinson's Disease. Nanotechnology 2016, 27 (43), 435101.

(40) Daina, A.; Michielin, O.; Zoete, V. SwissADME: A Free Web Tool to Evaluate Pharmacokinetics, Drug-Likeness and Medicinal Chemistry Friendliness of Small Molecules. Sci. Rep. 2017, 7, 42717.

(41) Baell, J. B.; Holloway, G. A. New Substructure Filters for Removal of Pan Assay Interference Compounds (PAINS) from 
Screening Libraries and for Their Exclusion in Bioassays. J. Med. Chem. 2010, 53 (7), 2719-2740.

(42) Zhou, M.; Panchuk-Voloshina, N. A One-Step Fluorometric Method for the Continuous Measurement of Monoamine Oxidase Activity. Anal. Biochem. 1997, 253 (2), 169-174. 